CARINA OLIVEIRA LOPES KULISHEV

\title{
PAPEL DA RESPOSTA SOS NO REPARO DE DANOS INDUZIDOS \\ POR MITOMICINA C E NA RESPOSTA AOS ANTIBIÓTICOS \\ BETA-LACTÂMICOS EM Caulobacter crescentus
}

\begin{abstract}
Dissertação apresentada ao Programa de Pós-Graduação em Microbiologia do Instituto de Ciências Biomédicas da Universidade de São Paulo, para obtenção do título de Mestre em Ciências.
\end{abstract}

São Paulo

2014 


\section{CARINA OLIVEIRA LOPES KULISHEV}

PAPEL DA RESPOSTA SOS NO REPARO DE DANOS INDUZIDOS POR MITOMICINA C E NA RESPOSTA AOS ANTIBIÓTICOS BETA-LACTÂMICOS

EM Caulobacter crescentus

Dissertação apresentada ao Programa de Pós-Graduação em Microbiologia do Instituto de Ciências Biomédicas da Universidade de São Paulo, para obtenção do título de Mestre em Ciências.

Área de Concentração:

Microbiologia

Orientador: Dr. Rodrigo da Silva Galhardo

Versão original 
DADOS DE CATALOGAÇÃO NA PUBLICAÇÃO (CIP)

Serviço de Biblioteca e Informaçăo Biomédica do

Instituto de Ciências Biomédicas da Universidade de São Paulo

reproduçăo năo autorizada pelo autor

Kulishev, Carina Oliveira Lopes.

Papel da resposta SOS no reparo de danos induzidos por mitomicina C e na resposta aos beta-lactâmicos em Caulobacter crescentus I Carina Oliveira Lopes Kulishev. -- São Paulo, 2014.

Orientador: Prof. Dr. Rodrigo da Silva Galhardo.

Dissertação (Mestrado) - Universidade de São Paulo. Instituto de Ciências Biomédicas. Departamento de Microbiologia. Área de concentração: Microbiologia. Linha de pesquisa: Reparo de DNA e mutagênese em bactérias. Controle da expressão gênica em bactérias.

Versão do título para o inglês: Role of the SOS response in the repair of damage induced by mitomycin $\mathrm{C}$ and in the response to beta-lactams in Caulobacter crescentus.

$\begin{array}{lll}\text { 1. Resposta SOS 2. Mutagênese } & 3 \text {. Caulobacter crescentus }\end{array}$ 4. Mitomicina C 5. Antibióticos beta-lactâmicos I. Galhardo, Prof. Dr. Rodrigo da Silva II. Universidade de São Paulo. Instituto de Ciências Biomédicas. Programa de Pós-Graduação em Microbiologia III. Título. 
UNIVERSIDADE DE SÃO PAULO

INSTITUTO DE CIÊNCIAS BIOMÉDICAS

\begin{abstract}
Candidato(a): $\quad$ Carina Oliveira Lopes Kulishev.
Titulo da Dissertaçăo: $\quad$ Papel da resposta SOS no reparo de danos induzidos por mitomicina $\mathrm{C}$ e na resposta aos beta-lactâmicos em Caulobacter crescentus.
\end{abstract}

Orientador(a): $\quad$ Prof. Dr. Rodrigo da Silva Galhardo.
A Comissão Julgadora dos trabalhos de Defesa da Dissertação de Mestrado, em sessão pública realizada a ....................................................., considerou
( ) Aprovado(a) （ ) Reprovado(a)

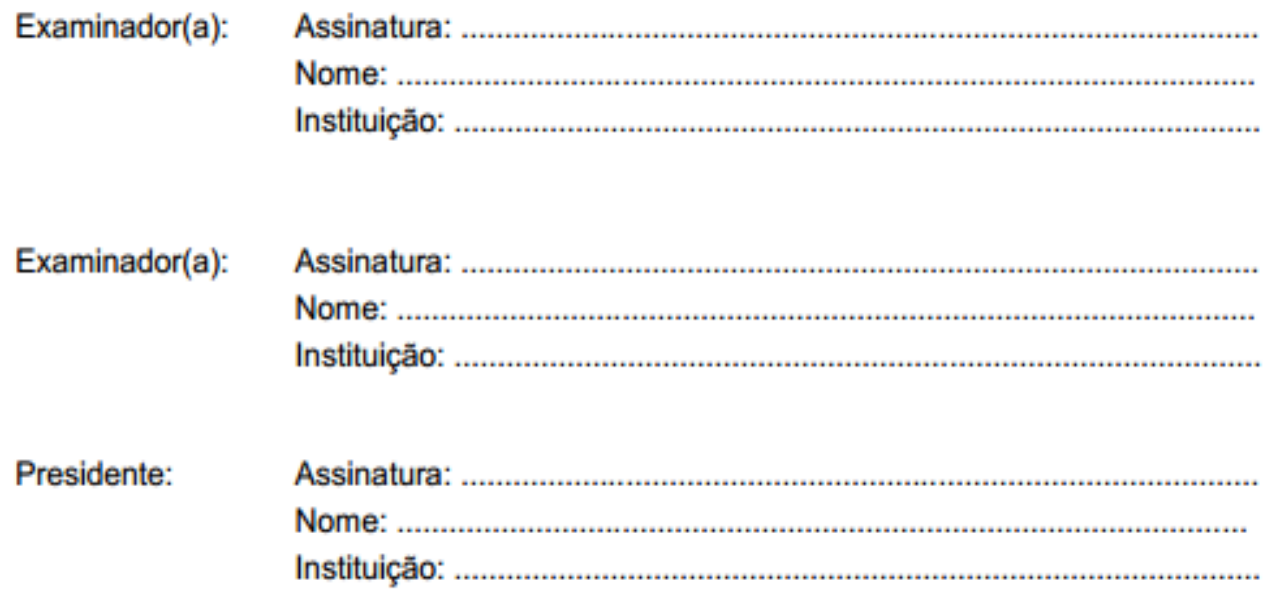




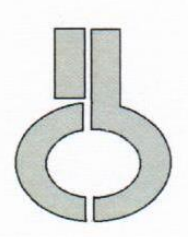

UNIVERSIDADE DE SÃO PAULO

INSTITUTO DE CIÊNCIAS BIOMÉDICAS

Cidade Universitária "Armando de Salles Oliveira"

Av. Prof. Lineu Prestes, 2415 - CEP. 05508-000 Săo Paulo, SP - Brasil

Telefone :(55) (11) 3091-7733 - telefax : (55) (11) 3091-8405

e-mail: cep@icb.usp.br

Comissão de Ética em Pesquisa

\section{CERTIFICADO DE ISENÇÃO}

Certificamos que o Protocolo CEP-ICB N $\mathrm{N}^{\circ}$ 517/12 referente ao projeto intitulado: "Papel da resposta SOS no reparo de DNA e mutagênese em Caulobacter crescentus" sob a responsabilidade de Carina Oliveira Lopes, foi analisado na presente data pela CEUA - COMISSÃO DE ÉTICA NO USO DE ANIMAIS e pela CEPSH- COMISSÃo DE ÉTICA EM PESQUISA COM SERES HUMANOS, tendo sido deliberado que o referido projeto não utilizará animais que estejam sob a égide da lei 11.794 de 8 de outubro de 2008, nem envolverá procedimentos regulados pela Resolução CONEP n¹96 de 1996.

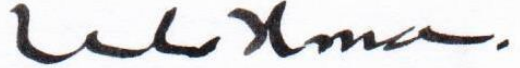

PROF. DR. Wothan TAVARES DE LIMA Coordenador da CEUA - ICB/USP
São Paulo, 10 de abril de 2012.

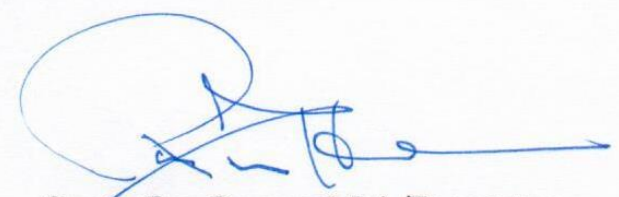

PBOF. DR. PAOLO M.A ZANOTTO Coordenador da CEPsh - ICB/USP 
Aos meus pais amados, Francisco e Vânia, por sempre estarem ao meu lado e fazerem tudo por mim.

Às minhas irmãs, carolina e Camila, por todo $\sigma$ amor, amizade $e$ companheirismo.

Ao men marido Nikolay, pelo incentivo, amor incondicional e carinho.

Ao mew anjo, Lamartine, por sempre me proteger. 


\section{AGRADECIMENTOS}

Ao meu orientador, Prof. Dr. Rodrigo da Silva Galhardo pelos ensinamentos, acolhimento em seu laboratório, disponibilidade, dedicação e confiança. Foi um previlégio fazer parte do seu grupo de pesquisa durante este período. Obrigada pela oportunidade e orientação!

Aos colegas de laboratório Alexy, Ingrid, Marco, Ellen, Dessiré, Maria Inès e Vânia pelo convívio e conversas ao longo deste período.

Aos colegas dos laboratórios da Prof. ${ }^{\text {a }}$ Marilis do Valle Marques e Prof. Carlos Frederico Martins Menck, em especial, Marinalva, Clarissa, Leonardo, Ricardo, Maristela e Juliana, pela ajuda e sugestões.

Aos Prof. Carlos Frederico Martins Menck e Prof. ${ }^{a}$ Marilis do Valle Marques, pela ajuda, conselhos e pela disponibilidade em sempre me ajudar.

Aos professores da banca de qualificação pelas sugestões.

À técnica Maria Helena pela convivência e ajuda.

Ao seviço de esterilização, em especial ao Senhor José, pela ajuda no preparo dos materiais.

Aos funcionários da Biblioteca pela competência e auxílio na formatação deste trabalho.

À secretária Gisele e ao funcionário Celso pela prontidão em sempre me ajudar com as questões burocráticas.

À Fapesp e CNPq pelo auxílio financeiro. 
Aos meus pais, Francisco e Vânia, pela preocupação e amor.

Às minhas irmãs, Carolina e Camila, pela amizade, amor e companhia.

Ao meu marido, Nikolay, por sempre estar ao meu lado e pelo amor infinito.

A toda minha família e amigos, em especial minhas avós e avôs (in memorian), Tio Márcio, Tia Mara, Geraldo, Alexandre, Carlos, Igor, Daniela, Marcela e Simone, pelo amor, preocupação e presença.

Ao Lamartine (in memorian), que onde quer que esteja nunca deixou de me proteger. 


\section{RESUMO}

KULISHEV, C. O. L. Papel da resposta SOS no reparo de danos induzidos por mitomicina C e na resposta aos beta-lactâmicos em Caulobacter crescentus. 2014. 110 f. Dissertação (Mestrado em Microbiologia) - Instituto de Ciências Biomédicas, Universidade de São Paulo, São Paulo, 2014.

O sistema SOS é o principal paradigma de resposta celular a danos no DNA em procariotos. Este regulon controla a expressão de diversos genes, muitos envolvidos em mecanismos de reparo de DNA. O sistema SOS foi extensamente estudado em Escherichia coli, sendo que recentemente este regulon vem sendo caracterizado em outros organismos. Dentre eles, a Caulobacter crescentus vem emergindo como um modelo bacteriano alternativo interessante para o estudo de mecanismos de reparo de DNA e mutagênese. A caracterização de genes pertencentes ao sistema SOS em outros organismos demonstrou que as características da resposta SOS de $E$. coli não são universais. Recentemente, foram identificados em $C$. crescentus 37 genes pertencentes ao regulon SOS, sendo muitos de função desconhecida. O enfoque principal deste trabalho é aprofundar os estudos sobre a resposta SOS no modelo de C. crescentus e seu papel no reparo de DNA e mutagênese. Temos como objetivos específicos realizar uma análise funcional de alguns genes de função desconhecida regulados pela resposta SOS, e investigar os efeitos biológicos da indução deste regulon por antibióticos beta-lactâmicos em C. crescentus. Análises funcionais dos genes CC_3424 e CC_3467 mostraram que deleções nestes genes resultam em fenótipo de sensibilidade à mitomicina $\mathrm{C}$ (MMC). CC_3424 é conservado entre diferentes espécies bacterianas e a proteína codificada por este gene apresenta domínios de similaridade com glioxalases e dioxigenases. CC_3467 é conservado em várias alfa-proteobactérias, e possui similaridade com endonucleases. Os mecanismos de reparo de ligações cruzadas intercadeia (ICLs) no DNA podem ser dependentes de recombinação homóloga ou mediados pela via de Síntese Translesão (TLS). Ensaios de análise epistática mostraram que o gene CC_3424 não participa da mesma via que NER, TLS e recombinação homóloga na tolerância à MMC, enquanto que o gene CC_3467 atua na mesma via que NER e TLS no reparo destes danos. Acreditamos que o gene CC_3467 exerça função no reparo de ICLs, já que endonucleases são cruciais nestes mecanismos, e que CC_3424 atue detoxificando a MMC das células. Estudos dos efeitos biológicos da indução do sistema SOS por antibióticos beta-lactâmicos mostram que a cefalexina, um betalactâmico, induz este regulon em concentrações subinibitórias. Verificamos que cepas deficiente nos genes $o x y R$, uvrA, $\operatorname{dnaE2}$ e $\operatorname{din} B$ são mais sensíveis a este antibiótico. Além disto, ensaios de mutagênese induzida por cefalexina mostraram que as cepas mutantes mutM e mutY apresentaram maior mutagênese após tratamento com cefalexina. Ensaios slot blot demostraram que células tratadas com concentrações subinibitórias de cefalexina apresentam maior concentração de danos oxidativos do tipo 8-oxoguanina. Estes resultados demonstram que concentrações subinibitórias de cefalexina resultam em estresse oxidativo em $C$. crescentus, e que os danos 8-oxoguanina são as principais lesões formadas no DNA.

Palavras-chave: Resposta SOS. Mutagênese. Caulobacter crescentus. Mitomicina C. Betalactâmicos. 


\begin{abstract}
KULISHEV, C. O. L. Role of the SOS response in the repair of damage induced by mitomycin $\mathbf{C}$ and in the response to beta-lactams in Caulobacter crescentus. 2014. $110 \mathrm{p}$. Masters thesis (Microbiology) - Instituto de Ciências Biomédicas, Universidade de São Paulo, São Paulo, 2014.
\end{abstract}

The SOS response is the main paradigm for cellular responses to DNA damage in prokaryotes. This regulon controls the expression of several genes, many of which are involved in DNA repair mechanisms. The SOS response has been extensively studied in Escherichia coli, but recently it has also started to be better characterized in other organisms. Caulobacter crescentus has emerged as an interesting alternative bacterial model for DNA repair and mutagenesis studies. The characterization of SOS genes in other organisms has shown that $E$. coli SOS response characteristics are not universal. Recently, 37 genes composing the SOS regulon of $C$. crescentus have been identified and most of those encode proteins of unknown function. The main goal of this proposal is to obtain a better understanding about the SOS response in C. crescentus and its role in DNA repair and mutagenesis. As specific aims, we will undertake a functional analysis of some of the genes regulated by the SOS response, and will investigate the biological effects of the sos induction by beta-lactam antibiotics in C. crescentus. Functional analysis of the genes CC_3424 and CC_3467 showed that deletions in these genes result in a phenotype of sensitivity to mitomycin C. CC_3424 is conserved in several species of bacteria and has similarity to Glyoxalase e Dioxygenase proteins. CC_3467 is conserved in alpha-proteobacteria and has similarity to endonucleases. The mechanisms of interstrand crosslinks (ICLs) repair in the DNA are dependent on homologous recombination or Translesion Synthesis (TLS). Epistasis analysis showed that the gene CC_3424 does not participate in the same pathway as NER, TLS and homologous recombination in MMC tolerance, while CC_3467 gene functions in the repair of such damages together with TLS and NER pathways. We believe that the CC_3467 gene plays a role in the repair of ICLs, as endonucleases are crucial in these mechanisms, while CC_3424 acts in MMC cellular detoxification. Studies of biological effects of SOS induction by cephalexin (beta-lactam) showed that subinibitory concentrations of these antibiotics induce the SOS regulon. We also found that strains deficient in $\operatorname{oxy} R, \operatorname{dnaE2}$, $\operatorname{din} B$ and $u v r A$ genes are more sensitive to this antibiotic. In addition, mutagenesis experiments showed that subinibitory concentrations of cephalexin induced larger mutagenesis increases in mutM and mut $Y$ deficient mutants strains after treatment with this antibiotic. Slot blot assays showed that cells treated with subinibitory concentrations of cephalexin have higher concentrations of 8-oxoG oxidative damage compared with untreated cells, suggesting that this antibiotic induces the formation of these lesions in DNA of $C$. crescentus. Altogether, these results demonstrate that subinibitory concentrations of cephalexin leads to cellular oxidative stress in $C$. crescentus and the 8-oxoguanine damage is the major lesion formed in the DNA.

Keywords: SOS Response. Mutagenesis. Caulobacter crescentus. Mitomycin C. Betalactams. 


\section{LISTA DE ILUSTRAÇÕES}

Figura 1 - Danos originados no DNA por mitomicina C

Figura 2 - Representação esquemática da via de excisão de nucleotídeos em $E$. coli 22

Figura 3 - Representação esquemática da via de excisão de bases em E.coli 26

Figura 4 - Representação esquemática da oxidação de guanina para 8-oxoguanina 28

Figura 5 - Representação esquemática do sistema de reparo GO 29

Figura 6 - Representação esquemática da síntese translesão em procariotos. 31

Figura 7 - Representação esquemática dos mecanismos envolvidos no reparo de ligações cruzadas intercadeia em E.coli

Figura 8 - Representação esquemática da indução da resposta SOS 36

Figura 9 - Representação esquemática das construções plasmidiais para deleções nos genes CC_3424 e CC_3467 de C. crescentus

Figura 10 - Efeito das deleções gênicas em CC_3424, CC_3467 e CC_2040 na resistência à $\mathrm{H}_{2} \mathrm{O}_{2}$ em $C$. crescentus. 68

Figura 11 - Efeito das deleções gênicas em CC_3424, CC_3467, CC_2040 e CC_0627 na resistência à MMC em C. crescentus.

Figura 12 - Efeito das deleções gênicas em CC_3424, CC_3467, CC_2040 e CC_0627 na resistência à MMS em $C$. crescentus 70

Figura 13 - Efeito das deleções gênicas em CC_3424, CC_3467, CC_2040 e CC_0627 na resistência à UVC em C. crescentus. 70

Figura 14 - Efeito da deleção do gene CC_3467 na resistência à MMC em C. crescentus. ..72

Figura 15 - Efeito das deleções gênicas em dnaE2, uvrA e CC_3467 na resistência à MMC em C. crescentus.

Figura 16 - Efeito das deleções gênicas em CC_3424, dnaE2, recA e uvrA na resistência à MMC em C. crescentus. 76

Figura 17 - Efeito das deleções em CC_3424 e dnaE2 na resistência à MMC em $C$. crescentus. .76

Figura 18 - Efeito das deleções gênicas em CC_3424 e CC_3467 na resistência à MMC em C. crescentus. 
Figura 19 - Representação esquemática do reparo de ligações cruzadas intercadeia induzidas por mitomicina $\mathrm{C}$ em Caulobacter crescentus.

Figura 20 - Efeito das deleções gênicas em dnaE2, CC_3424, CC_3467, CC_2040 e CC_0627 na mutagênese induzida por luz UVC em C. crescentus utilizando o marcador de resistência a rifampicina

Figura 21 - Efeito das deleções gênicas em dnaE2, CC_3424, CC_3467, CC_2040 e CC_0627 na mutagênese induzida por luz UVC em C. crescentus utilizando o marcador de resistência a ampicilina.

Figura 22 - Testes de disco-difusão e a indução da atividade de PimuA frente a cefalexina e ciprofloxacina

Figura 23 - Testes de disco-difusão e a indução da atividade de PimuA frente a diferentes compostos antimicrobianos

Figura 24 - Testes de disco-difusão e a indução da atividade de PimuA frente a diferentes compostos antimicrobianos

Figura 25 - Efeito da cefalexina na expressão do promotor de imuA e no crescimento de $C$. crescentus.

Figura 26 - Efeito das deleções gênicas em dnaE2, mutM, mutY, recA, uvrA e oxyR na mutagênese induzida por cefalexina em $C$. crescentus

Figura 27 - Representação esquemática da indução da resposta SOS por concentrações subinibitórias de cefalexina em C. crescentus.

Figura 28 - Determinação imunológica de lesões 8-oxoG no DNA de C. crescentus após tratamento cefalexina

Figura A1 - Efeito das deleções gênicas em CC_3424, CC_3467, CC_2040 e uvrA na resistência à $\mathrm{H}_{2} \mathrm{O}_{2}$ em $C$. crescentus.

Figura A2 - Efeito das deleções gênicas em CC_3424, CC_3467, CC_2040, CC_0627 e uvrA na resistência à MMS em C. crescentus.

Figura A3 - Efeito das deleções gênicas em CC_3424, CC_3467, CC_2040 e uvrA na resistência à luz UVC em C. crescentus.

Figura A4 - Alinhamento da sequência de aminoácidos da proteína codificada pelo gene CC_3467 para análise de domínios de similaridade. 110

Figura A5 - Alinhamento da sequência de aminoácidos da proteína codificada pelo gene CC_3424 para análise de domínios de similaridade. 


\section{LISTA DE TABELAS}

Tabela 1 - Genes pertencentes à via de reparo de excisão de bases de Caulobacter crescentus

Tabela 2 - Genes identificados por análise in silico como componentes do regulon SOS em

C. crescentus. 40

Tabela 3 -Linhagens de Escherichia coli utilizadas neste trabalho 47

Tabela 4 - Linhagens de Caulobacter crescentus utilizadas neste trabalho 48

Tabela 5 - Plasmídeos utilizados neste trabalho 50

Tabela 6 - Oligonucleotídeos utilizados neste trabalho 51

Tabela 7 - Determinação da concentração inibitória mínima de cefalexina para diferentes cepas de $C$. crescentus 86 


\section{LISTA DE SIGLAS E ABREVIATURAS}

$\mu \mathrm{g}-$ micrograma

$\mu 1-$ microlitro

$\mu \mathrm{M}-$ micromolar

$6,4 \mathrm{PP}-6,4$ pirimidina pirimidona fotoproduto

8-oxG -8 oxoguanina

A, C, G, T - adenina, citosina, guanina, timina

Anti-8-oxoG - anticorpo anti-8 oxoguanina

AP - sítio apurínico ou apirimidinico

ATP - adenosina trifosfato

BER - reparo por excisão de bases

CFX - cefalexina

CIP - ciprofloxacina

CPD - dímero pirimidina ciclobutano

DMSO - dimetilsulfóxido

DNA - ácido desoxirribonucleico

$\mathrm{DO}_{420 \mathrm{~nm}}$ - densidade óptica a 420 nanômetros

$\mathrm{DO}_{600 \mathrm{~nm}}$ - densidade óptica a 600 nanômetros

DSB - quebra de fita dupla

EDTA - ácido etilenodiamino teracético

Fapy-G - 2,6-diamino-4-hidroxi-5-formamidopirimidina

Fpg - Formamidapirimidina

$\mathrm{g}$ - grama

GTP - guanosina trifosfato

$\mathrm{H}_{2} \mathrm{O}_{2}$ - Peróxido de hidrogênio

ICL - ligação cruzada

IPTG - isopropil- $\beta$-D-tiogalactopiranosídeo

1 - litro

LB - Lúria-Bertani

$\mathrm{M}-$ molar

CIM - concentração inibitória mínima 
MilliQ - água deionizada

$\mathrm{ml}$ - mililitro

$\mathrm{mM}$ - micromolar

MMC - mitomicina C

MMS -metilmetanosulfonado

NER - reparo por excisão de nucleotídeos

$\mathrm{OH} \bullet$ - radical hidroxila

ONPG - orto-nitrofenil- $\beta$-galactosídeo

$\mathrm{pb}$ - pares de bases

PBS - tampão fosfato salino

PCR - reação em cadeia da polimerase

pH - Potencial Hidrogeniônico

Pol - polimerase

ROS - espécies reativas de oxigênio

SSB - quebra de fita simples

TBE - tampão tris/borato/EDTA

$\mathrm{Tg}$ - timina glicol

TLS - síntese translesão

UFC - unidade formadora de colônia

UV - radiação ultravioleta

$\mathrm{xg}$ - força centrífuga aplicada

$\mathrm{X}$-gal - 5-bromo-4-cloro-3-indolil- $\beta$-D-galactopiranosídeo

$\alpha-$ alfa

$\beta-$ beta

$\lambda$ - lambda

$\Phi-\mathrm{fi}$

$\Omega-$ omega 


\section{SUMÁRIO}

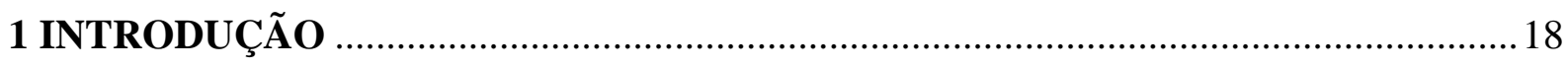

1.1 Danos no DNA e vias de reparo e tolerância em bactérias ........................................ 18

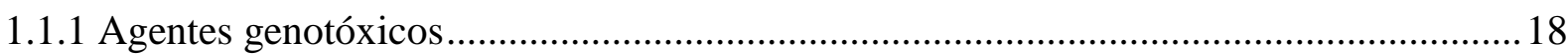

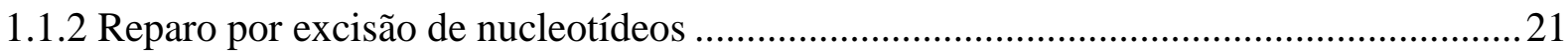

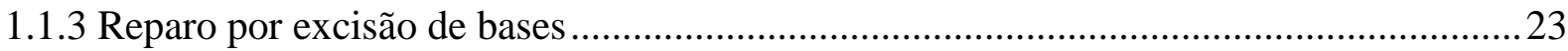

1.1.3.1 Sistema GO

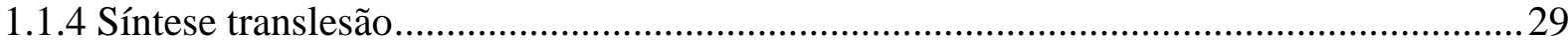

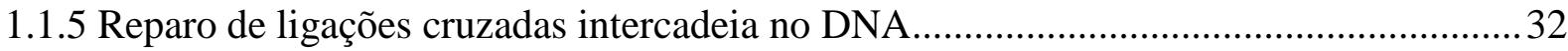

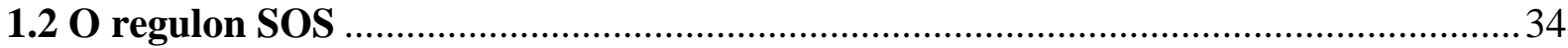

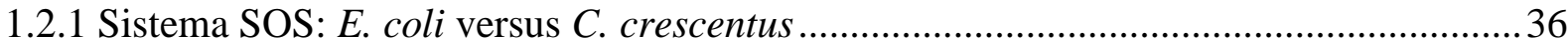

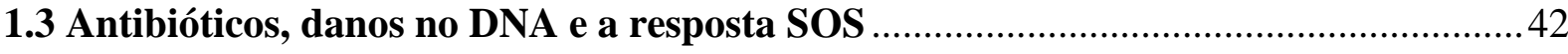

1.4 Antibióticos beta-lactâmicos e o estresse oxidativo ….............................................. 44

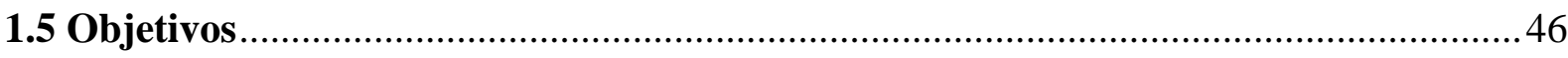

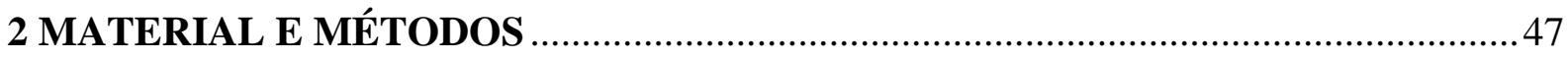

2.1 Linhagens Bacterianas e condições de cultivo e manutenção.................................... 47

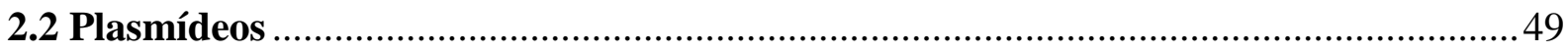

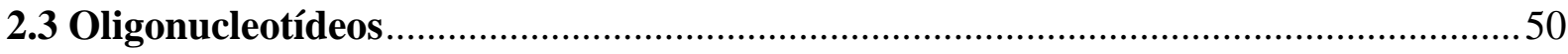

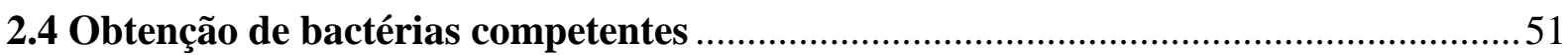

2.5 Transformação de células competentes por choque térmico .....................................52

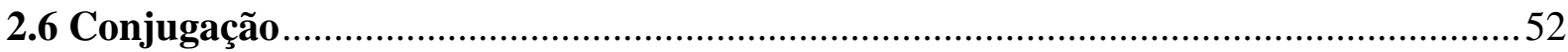

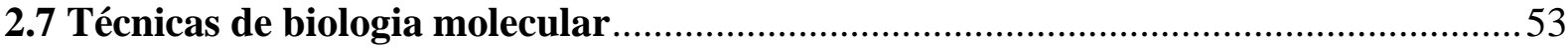

2.7.1 Extração de DNA cromossomal de $C$. crescentus .........................................................53

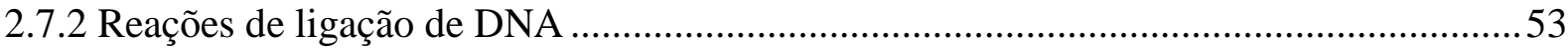

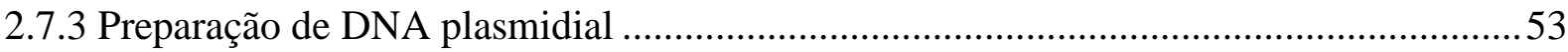


2.7.5 Reação para sequenciamento de DNA e precipitação ....................................................54

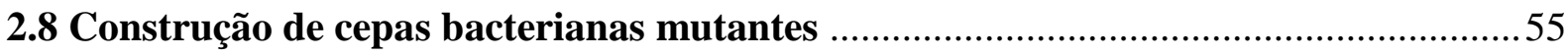

2.8.1 Cepas bacterianas com genes interrompidos pelo transposon $\operatorname{Tn} 5$...............................55

2.8.2 Construção de cepas bacterianas por transdução com o bacteriófago $\Phi C r 30$.................56

2.8.3 Construção de cepas bacterianas utilizando o vetor pNPTS138 ..................................57

2.8.3.1 Construção dos vetores plasmidiais para deleções...................................................58

2.9 Ensaios de sobrevivência frente a agentes genotóxicos ............................................60

2.10 Ensaios de mutagênese frente a agentes genotóxicos ................................................. 61

2.11 Teste flutuação para determinação da mutagênese espontânea e induzida por

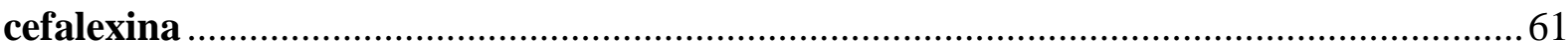

2.12 Ensaios para determinação da concentração inibitória mínima de cefalexina..........62

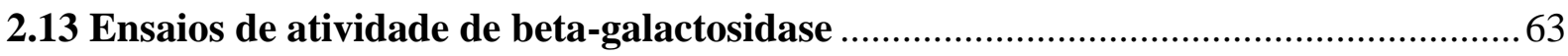

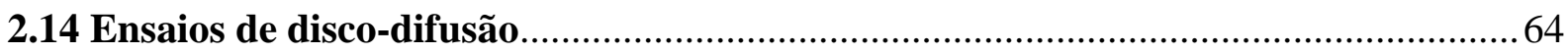

2.15 Ensaios de imuno slot-blot para determinação de lesões 8-oxoguanina ................... 64

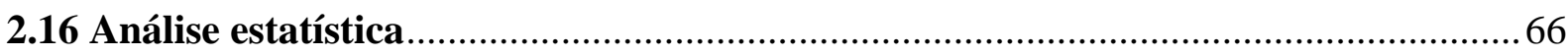

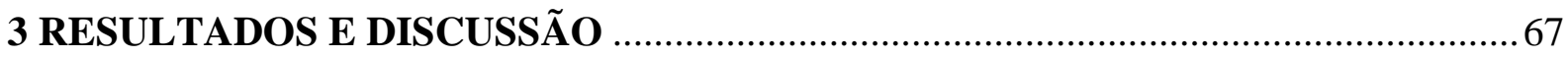

3.1 Análise funcional de alguns genes regulados pela resposta SOS em $C$. crescentus e seus papéis no reparo de DNA e mutagênese ..............................................................67

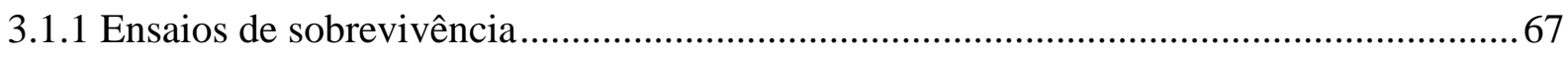

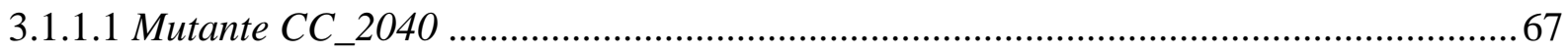

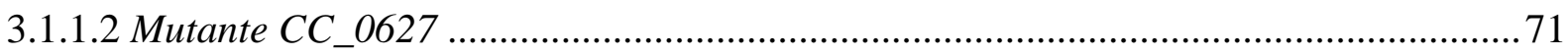

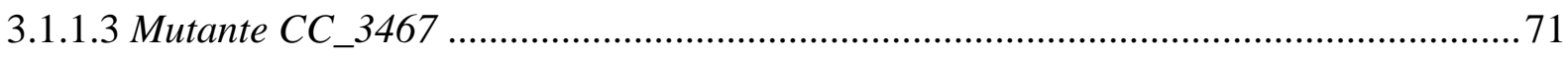

3.1.1.4 Mutante CC_3424 ............................................................................................ 74

3.1.1.5 Genes $C C \_3467$ e CC_3424 e a tolerância à mitomicina $C$......................................... 77

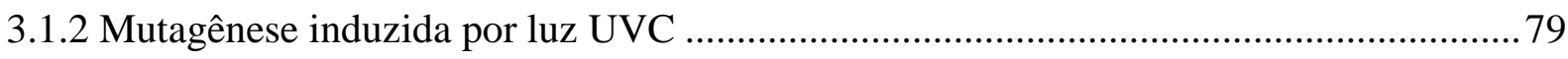


3.2 Estudo dos efeitos biológicos da indução do sistema SOS por antibióticos beta-

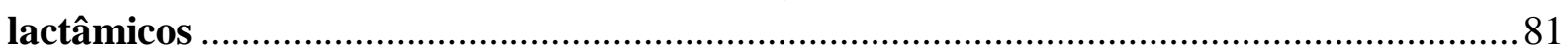

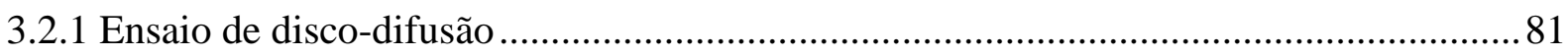

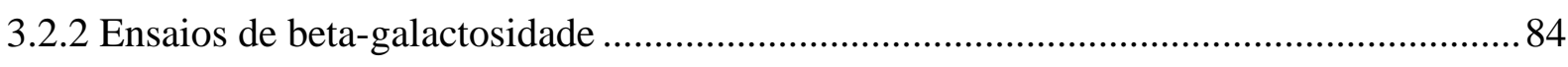

3.2.3 Ensaios de determinação da concentração inibitória mínima para cefalexina ................ 86

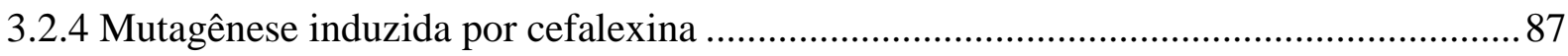

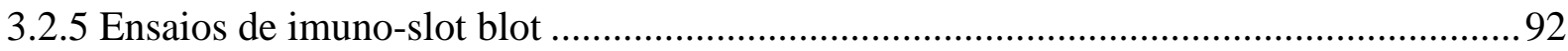

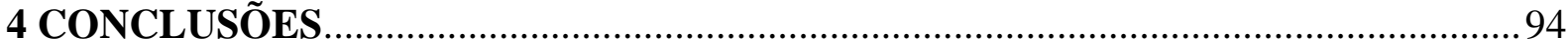

4.1 Análise funcional de genes pertencentes ao regulon SOS …....................................94

4.2 Efeitos biológicos da indução do sistema SOS por antibióticos beta-lactâmicos........ 94

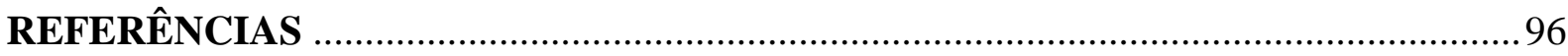

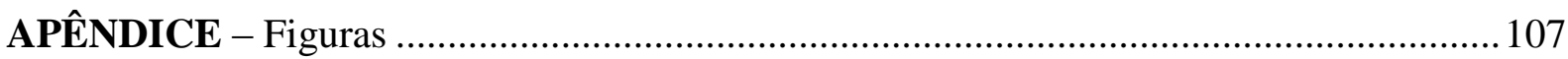




\section{INTRODUÇÃO}

\subsection{Danos no DNA e vias de reparo e tolerância em bactérias}

O DNA é uma importante molécula que mantém as informações genéticas celulares e, por isto, sua estabilidade e integridade são essenciais para a vida dos organismos. Os genomas celulares estão constantemente expostos a uma grande variedade de agentes endógenos e exógenos, que resultam em diferentes danos nas moléculas do DNA. Estes danos incluem, por exemplo, reações de desaminação, oxidação, alquilação e dimerização nas bases nucleotídicas, perda de bases, além de quebras simples ou duplas na molécula do DNA (TRUGLIO et al., 2006). Muitas destas lesões são extremamente deletérias para as células, e podem comprometer processos essenciais, como replicação e transcrição. Caso não sejam reparadas, muitas lesões podem levar a eventos mutagênicos ou citotóxicos (CLANCY, 2008). Para manter a integridade de seus genomas, os organismos desenvolveram diversos mecanismos de reparo de DNA capazes de lidar com diversas condições adversas (MILES; SANCAR, 1989). Além dos mecanismos de reparo de DNA responsáveis por removem os danos, as células também apresentam vias de tolerância ao dano que garantem a replicação do DNA quando as lesões não foram removidas (FRIEDBERG et al., 2006).

Nos próximos itens serão abordados alguns mecanismos de reparo e tolerância a danos no DNA, que serão importantes para o entendimento de vários aspectos abordados ao longo deste trabalho.

\subsubsection{Agentes genotóxicos}

Nesta seção serão abordados alguns aspectos relacionados aos agentes genotóxicos utilizados ao longo deste trabalho, são eles: luz ultravioleta (UV), peróxido de hidrogênio $\left(\mathrm{H}_{2} \mathrm{O}_{2}\right)$, mitomicina $\mathrm{C}$ (MMC) e metilmetanosulfonato (MMS). É importante ressaltar que as vias de induções de danos por estes compostos são muito complexas e, portanto, somente alguns pontos relevantes para o entendimento deste trabalho serão descritos.

A luz ultravioleta é um potente agente genotóxico e mutagênico, e quando absorvida diretamente pelo DNA, resulta em reações de dimerização entre bases pirimidinas adjacentes. Como consequência, dois danos principais são formados: dímeros de pirimidina ciclobutano 
(CPD) e, em menor grau, o fotoproduto 6-4 pirimidina-pirimidona (6-4PP) (FRIEDBERG et al., 2006). A lesão CPD envolve a formação de ligação covalente entre os carbonos 5 e 6 de bases pirimidinas adjacentes, originando um anel de ciclobutano. A lesão 6-4PP é caracterizada pela formação de uma ligação covalente entre pirimidinas adjacentes, entre os carbonos 4 e 6 (PFEIFER, 1997). As lesões do tipo CPD são cerca de 3 vezes mais frequentes que 6-4PP após exposição com luz UVC (FRIEDBERG et al., 2006). Além disto, lesões 64PP resultam em uma distorção na dupla hélice do DNA de $44^{\circ}$ enquanto que lesões CPD distorcem a molécula somente $30^{\circ}$ (KIM; CHOI, 1995; PARK et al., 2002). A sequência nucleotídica do DNA influencia na formação de ambas as lesões. Adutos do tipo CPD ocorrem com maior frequência entre T-T e menos frequentemente entre C-C (SETLOW; CARRIER, 1966), e danos 6,4PP ocorrem mais frequentemente entre T-C e C-C, e com menor frequência entre TT e CT (FRIEDBERG et al., 2006)

O metilmetanosulfonato é um composto alquilante monofuncional capaz de reagir covalentemente com um centro nucleofílico da molécula de DNA. Dentre os sítios que MMS modifica no DNA, podemos citar: posições N1, N3 e N7 da adenina e N3, N7 e O6 da guanina (FRIEDBERG et al., 2006). As modificações por este agente ocorrem mais frequentemente na guanina (N7) e adenina (N3), que resultam na formação de 7-metilguanina e 3-metiladenina, respectivamente (BERANEK, 1990).

O peróxido de hidrogênio é uma importante espécie química capaz de se difundir facilmente através das membranas celulares, e reagir com metais de transição (moléculas redutoras) através da reação de Fenton, formando o radical hidroxila $(\mathrm{OH} \bullet)$. Os metais de transição mais relevantes envolvidos nesta reação são $\mathrm{Cu}^{1+}$ e $\mathrm{Fe}^{2+}$ (FRIEDBERG et al., 2006). Radicais $\mathrm{OH} \bullet$ são extremamente reativos e resultam principalmente na retirada de átomos de hidrogênio do açúcar desoxirribose e adição de ligações insaturadas em bases nucleotídicas. Este agente pode resultar em severos danos à molécula de DNA, que incluem, por exemplo, quebras nas fitas do DNA e perda de bases (HALLIWELL, 1999).

A mitomicina C (MMC) é um antibiótico antitumoral isolado de Streptomycyces caespitosis utilizado como tratamento quimioterápico contra diversas enfermidades, incluindo tumor gastrointestinal, câncer pancreático, gástrico, colo-retal e anal (HOFHEINZ et al., 2008). A forma intacta da molécula de MMC não é capaz de reagir e resultar em danos no DNA, para isto, estas moléculas devem passar por reações espontâneas que garantem a conversão desta molécula para forma alquilante, ativa e lesiva ao DNA. Esta conversão 
envolve reações de modificações enzimáticas ou reduções químicas alquilantes no grupo quinona desta molécula, e culmina com a formação de uma instável molécula alquilante altamente reativa. A forma alquilada da MMC atua preferencialmente nos resíduos 2deoxiguanosina $(\mathrm{dG})$ no sulco menor da hélice do DNA. O ataque desta molécula no DNA pode ser mediado por uma ou duas reações de alquilação, e isto é determinante para o tipo de dano formado no DNA (Figura 1). A ocorrência de somente uma ativação alquilante resulta na formação de danos do tipo monoadutos- $\mathrm{dG}$, e duas reações alquilantes culminam com a formação de três tipos distintos de danos: ligações cruzadas intercadeia, intracadeia ou monoaduto. Porém, as ligações cruzadas intracadeia ocorrem com menor frequência em relação aos demais danos (TOMASZ, 1995).

\section{Figura 1 - Danos originados no DNA por mitomicina C}

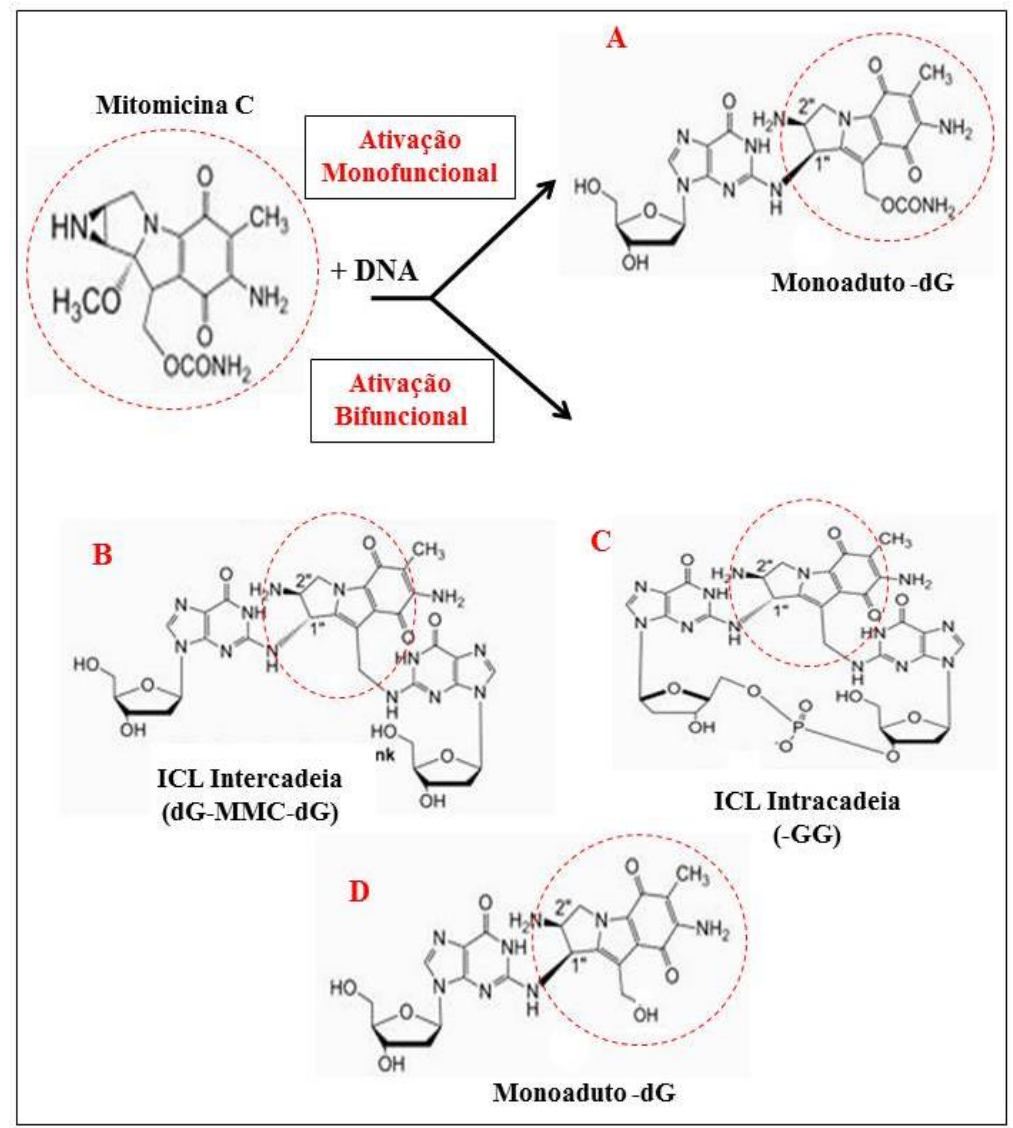

A ativação de somente uma função alquilante entre DNA e MMC resulta na formação de monoadutos, e a ativação de duas funções alquilantes resulta na formação de ligações intercadeia (B), Intracadeia (C) e monoaduto (D). As moléculas de mitomicina $\mathrm{C}$ estão destacadas com círculos vermelhos. Fonte: modificado de MCvey (2010) e Tomasz (1995). 


\subsubsection{Reparo por excisão de nucleotídeos}

O mecanismo de reparo por excisão de nucleotídeos (NER) é considerado um dos mais versáteis e flexíveis, por atuar no reparo de uma grande variedade de lesões que resultam em distorções significativas na dupla-hélice da molécula de DNA. Dentre os danos mais relevantes reparados pela via NER, destacam-se CPDs e 6-4PPs, principais lesões induzidas por luz UV (DE LAAT; JASPERS; HOEIJMAKERS, 1999; FRIEDBERG et al., 2006). Lesões do tipo 6-4PP resultam em distorções mais severas no DNA em relação a CPDs (PEARLMAN; PIRKLE; KIM, 1985), e lesões do tipo 6-4PP apresentam uma taxa de reconhecimento e incisão pela via NER superior ao observado para CPDs (CHANDRASEKHAR; VAN HOUTEN, 2000). Estes dados sugerem que, dependendo do grau de distorção na molécula de DNA, os danos são reconhecidos e reparados de modo mais eficiente.

Em E. coli a via NER é mediada pelos genes $u v r A B C$ (VAN HOUTEN et al., 2005), e esta via compreende essencialmente as seguintes etapas: reconhecimento e verificação do dano, excisão do trecho de ssDNA afetado, e ressíntese deste fragmento utilizando a fita complementar como molde (KUPER; KISKER, 2012). O reconhecimento da lesão é realizado pelas enzimas UvrA e UvrB, associadas como um heterotrímero ( $\mathrm{UvrA}_{2} \mathrm{UvrB}$ ) ou heterotetrâmero $\left(\mathrm{UvrA}_{2} \mathrm{UvrB}_{2}\right)$. A proteína UvrB possui função ATPase, e atua alterando a conformação do DNA possibilitando o reconhecimento da lesão por UvrC, que interage com o domínio do carboxi-terminal de UvrB e incisa o trecho afetado a $3{ }^{`}$ e 5 'da lesão (TRUGLIO et al., 2006). A UvrC catalisa uma incisão quatro ligações fosfodiéster a 3 do dano e outra incisão oito ligações a 5 deste, liberando um fragmento de 12 nucleotídeos contendo o dano (VAN HOUTEN et al., 2005). A enzima UvrD (DNA helicase II) atua então removendo este fragmento e liberando a proteína UvrC do complexo enzimático, e a DNA polimerase I ressintetiza o fragmento de DNA, que é ligado ao DNA original pela DNA ligase I (TRUGLIO et al., 2006). Em E. coli, uvrA e uvrB são regulados pelo regulon SOS (seção 1.2), enquanto que $u v r C$ é expresso constitutivamente. A figura 2 esquematiza as etapas envolvidas na via NER em E. coli. 
Figura 2 - Representação esquemática da via de excisão de nucleotídeos em $E$. coli

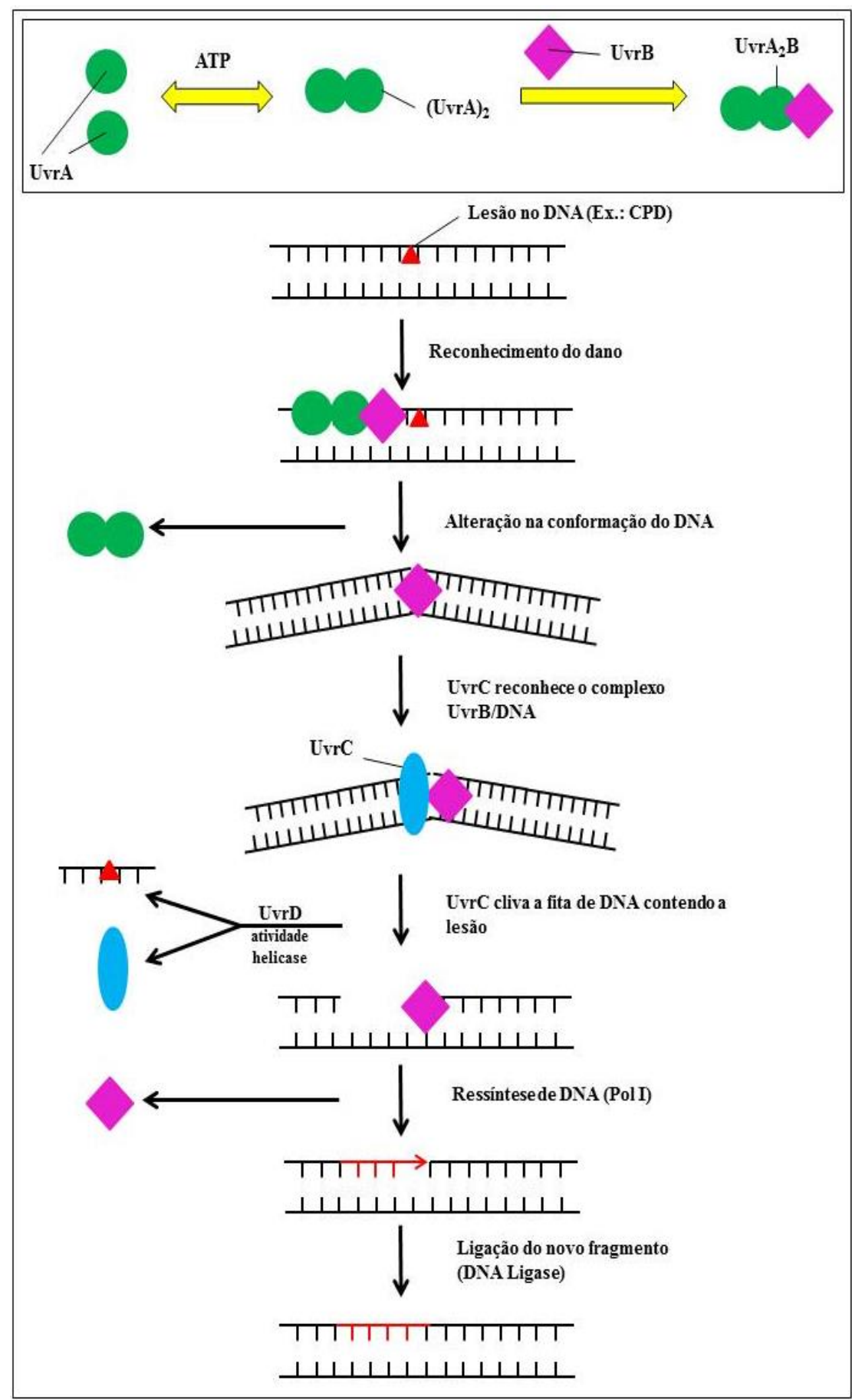

Proteínas UvrA se associam e formam dímero $\left(\mathrm{UvrA}_{2}\right)$ em presença de ATP. $(\mathrm{UvrA})_{2}$ interage com UvrB resultando no complexo $\mathrm{UvrA}_{2} \mathrm{~B}$, o qual reconhece e se liga a lesão. Esta ligação desencadeia mudanças conformacionais no complexo, seguido de liberação das moléculas de UvrA. UvrC reconhece o complexo UvrB/DNA e catalisa duas incisões no DNA, uma à 5 `e outra a 3 'do dano. A UvrD Helicase remove e sequência excisada (12 nucleotídeos) e libera a proteína UvrC do complexo. DNA polimerase I ressintetiza um fragmento de DNA utilizando a outra fita de DNA como molde, e a DNA ligase finalmente liga este novo fragmento ao DNA. 
Estudos demonstraram que E. coli possui um gene regulado pela resposta SOS denominado $y d j Q$ (ou cho) que codifica a proteína Cho, envolvida na via NER (MOOLENAAR et al., 2002). Esta proteína apresenta similaridade com o domínio N-terminal de UvrC, e também é capaz de incisar o DNA à 3`da lesão, na presença de UvrB e UvrA (MOOLENAAR et al., 2002). Moolenaar e colaboradores (2002) demonstraram que em alguns tipos de danos no DNA, a incisão desempenhada por Cho na extremidade 3 da lesão é mais eficiente que a incisão realizada por UvrC. Eles propõem que a maioria das lesões são reparadas, a princípio, pela ação de UvrC, e os danos remanescentes são reparados pela ação conjunta das proteínas Cho e UvrC, que promovem incisões a 3`e 5`do dano, respectivamente.

\subsubsection{Reparo por excisão de bases}

O reparo por excisão de bases (BER) é provavelmente a via de reparo mais frequentemente utilizada na natureza, considerando que modificações de bases nucleotídicas ocorrem frequentemente no genoma das células (FRIEDBERG et al., 2006). A via BER apresenta um importante papel em evitar efeitos mutagênicos e citotóxicos mediados por danos no DNA, e atua em diversos tipos de lesões, como: nucleotídeos alterados, sítios abásicos, quebras na cadeia do DNA por agentes alquilantes, oxidativos ou radiações ionizantes (KIM; WILSON III, 2012). A via BER é considerada o principal mecanismo para remoção de lesões endógenas no DNA que causam pequenas distorções na dupla hélice do DNA (LINDAHL, 1993). Dentre os processos endógenos celulares que resultam em danos no DNA, incluem-se, por exemplo, reações hidrolíticas, como desaminação hidrolítica da citosina, guanina e adenina e reações oxidativas mediadas por espécies reativas de oxigênio (ROS) (KROKAN; STANDAL; SLUPPHAUG, 1997).

A via BER é iniciada por uma classe especial de enzimas denominada DNA glicosilases, que reconhecem especificamente determinadas bases modificadas ou pareadas de modo inapropriado, e promovem a quebra da ligação N-glicosídica, removendo a base nitrogenada (FRIEDBERG et al., 2006). A bactéria E. coli apresenta oito tipos diferentes de DNA glicosilases descritas em seu genoma, incluindo Ung, Mug, Fpg, MutY, Nth, TagA, AlkA e Nei. Por outro lado, nosso modelo de estudo, C. crescentus, possui quase todas as glicosilases descritas para E. coli, com exceção da endonuclease VIII, codificada pelo gene nei (Tabela 1). 
Tabela 1 - Genes pertencentes à via de reparo de excisão de bases de Caulobacter crescentus

\begin{tabular}{|c|c|c|c|}
\hline $\begin{array}{c}\text { Gene de } \\
\text { E. coli }\end{array}$ & $\begin{array}{c}\text { Locus em } \\
\text { C. crescentus }\end{array}$ & Descrição & Característica \\
\hline mutY & $\begin{array}{c}\text { CC_0377 } \\
(\text { CCNA_00381) }\end{array}$ & Adenina glicosilase & $\begin{array}{c}\text { Glicosilase } \\
\text { Monofuncional }\end{array}$ \\
\hline mutM (fpg) & $\begin{array}{c}\text { CC_3707 } \\
(\text { CCNA_03822) }\end{array}$ & $\begin{array}{l}\text { Formamidopirimidina DNA } \\
\text { glicosilase }\end{array}$ & Glicosilase Bifuncional \\
\hline$x t h A$ & $\begin{array}{c}\text { CC_3706 } \\
(\mathrm{CCNA} 03821)\end{array}$ & Exodeoxiribonuclease III & AP endonuclease \\
\hline & $\begin{array}{c}\text { CC_2011 } \\
(\mathrm{CCNA} 02090)\end{array}$ & Exodeoxiribonuclease III & AP endonuclease \\
\hline ung & $\begin{array}{c}\text { CC_2084 } \\
(\mathrm{CCNA} 02166)\end{array}$ & Uracil-DNA-glicosilase & $\begin{array}{c}\text { Glicosilase } \\
\text { Monofuncional }\end{array}$ \\
\hline & $\begin{array}{c}\text { CC_1333 } \\
(\text { CCNA_01394) }\end{array}$ & Uracil-DNA-glicosilase & $\begin{array}{c}\text { Glicosilase } \\
\text { Monofuncional }\end{array}$ \\
\hline & $\begin{array}{c}\text { CC_2333 } \\
(\text { CCNA_02418) }\end{array}$ & Uracil-DNA-glicosilase & $\begin{array}{c}\text { Glicosilase } \\
\text { Monofuncional }\end{array}$ \\
\hline & $\begin{array}{c}\text { CC_1549 } \\
(\mathrm{CCNA} 01618)\end{array}$ & Uracil-DNA-glicosilase & $\begin{array}{c}\text { Glicosilase } \\
\text { Monofuncional }\end{array}$ \\
\hline nth & $\begin{array}{c}\text { CC_2272 } \\
(\mathrm{CCNA} \text {-02355) }\end{array}$ & Endonuclease III & Glicosilase Bifuncional \\
\hline & $\begin{array}{c}\text { CC_3731 } \\
(\text { CCNA_03847) }\end{array}$ & Endonuclease III & Glicosilase Bifuncional \\
\hline $\operatorname{tag} A$ & $\begin{array}{c}\text { CC_0382 } \\
(\text { CCNA_00386) }\end{array}$ & $\begin{array}{c}\text { 3-Metiladenina DNA } \\
\text { glicosilase I }\end{array}$ & $\begin{array}{c}\text { Glicosilase } \\
\text { Monofuncional }\end{array}$ \\
\hline alkA & $\begin{array}{c}\text { CC_2201 } \\
(\text { CCNA_02284) }\end{array}$ & $\begin{array}{c}\text { 3-metil-adenina DNA } \\
\text { glicosilase II }\end{array}$ & $\begin{array}{c}\text { Glicosilase } \\
\text { Monofuncional }\end{array}$ \\
\hline
\end{tabular}


Em geral, as DNA glicosilases atuam de maneira específica no reconhecimento de determinadas bases nucleotídicas pareadas erroneamente ou contendo danos. Estas enzimas podem ser monofuncionais, ou seja, atuam removendo somente a base nucleotídica e deixam um sitio abásico (AP), ou bifuncionais que apresentam também atividade liase, promovendo a quebra do DNA a 3`do sítio AP (KROKAN; STANDAL; SLUPPHAUG, 1997).

A remoção dos sítios AP pode ser mediada por AP endonucleases e também por AP liases. As enzimas AP endonucleases hidrolisam a ligação fosfodiéster na porção 5 do sítio AP, originando uma extremidade $3 ` \mathrm{OH}$ e outra 5 fosfato-desoxirribose. Estas enzimas são também responsáveis por remover sítios AP resultantes de eventos espontâneos na molécula do DNA. O resíduo 5 fosfato-desoxirribose $(5 \mathrm{dRP})$ originado após a atividade das AP endonucleases é removido por enzimas DNA desoxirribo-fosfodiesterase (dRpases). Alternativamente, se o resíduo 5 dRP sofrer alguma alteração e não puder ser removido pelas dRpases, o reparo pode envolver a substituição de 2-10 nucleotídeos da fita danificada. Neste caso, a DNA polimerase promove um deslocamento nos nucleotídeos da fita contendo o dano, gerando uma protuberância ("flap") que contém um resíduo dRP na extremidade 5", que é clivado por flap endonucleases, e o nucleotídeo unido pela DNA ligase (DIANOV; PRICE; LINDAHL, 1992; LIU; KAO; BAMBARA, 2004).

As glicosilases com atividade AP liase incisam o DNA por uma reação de $\beta$ eliminação que resulta em resíduos desoxinucleosídeo-5'-fosfato 5'-terminal e aldeídos 3'terminal $\alpha \beta$-insaturados. O terminal 3`-fosfato e os aldeídos insaturados são processados pela enzima 3' fosfodiesterase (DEMPLE; HARRISON, 1994). Após a excisão da base danificada e do resíduo de desoxirribosefosfato, uma nova base nucleotídica é sintetizada e ligada ao DNA pela ação das enzimas DNA polimerase I e DNA ligase, respectivamente (FRIEDBERG et al., 2006).

O reparo de excisão de bases envolve basicamente 5 etapas: remoção da base contendo o dano ou base inapropriada resultando na formação do sitio AP, incisão da ligação fosfodiéster, remoção de resíduos 5'-fosfato-desoxirribose, reconhecimento e complementação da lacuna gerada na cadeia do DNA pela DNA polimerase I, e finalmente, a ligação do nucleotídeo recém introduzido na fita de DNA pela DNA ligase (FRIEDBERG et al., 2006; ZHARKOV, 2008). A Figura 3 esquematiza as etapas envolvidas na via BER. 
Figura 3 - Representação esquemática da via de excisão de bases em E.coli

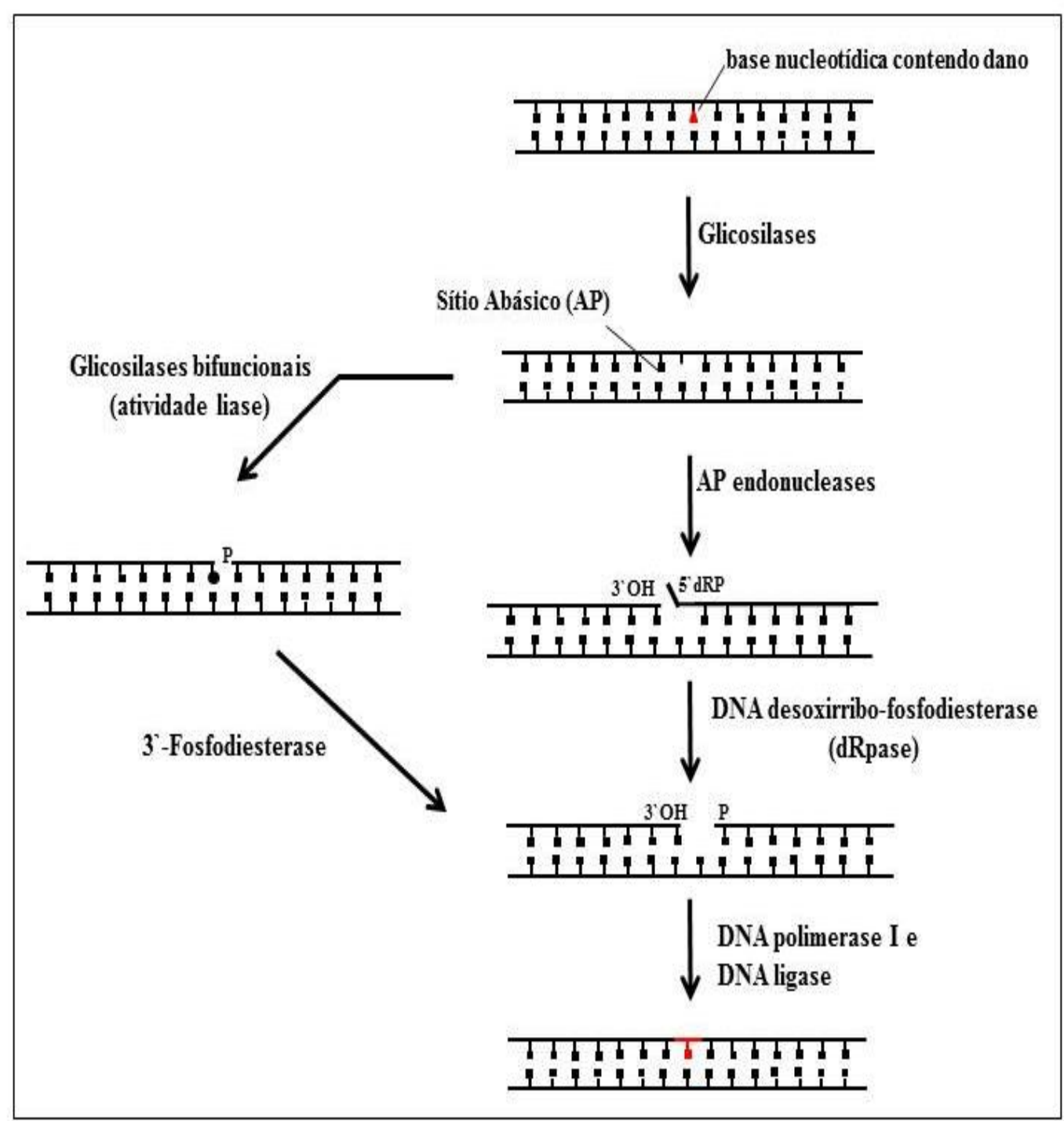

As DNA glicosilases são responsáveis por iniciar a via BER. Estas enzimas reconhecem e removem bases nucleotídicas contendo danos, gerando um sítio AP. Enzimas AP endonucleases promovem a remoção destes sítios AP, gerando um resíduo 5 fosfato-desoxirribose, que são removidos pela enzima desoxirribo-fosfodiesterase (dRpase). As enzimas AP liases incisam o DNA e resultam em resíduos desoxinucleosídeo-5'-fosfato 5'-terminal e aldeídos 3'-terminal $\alpha \beta$-insaturados, que são processados por 3' fosfodiesterases. A DNA polimerase sintetiza um novo nucleotídeo e a DNA ligase promove a ligação deste ao DNA original.

\subsubsection{Sistema $G O$}

Em procariotos, enzimas atuam em um elaborado sistema de reparo denominado sistema GO, que atua frente a danos do tipo 8 oxoguanina (8-oxo-7,8-dihidroguanina; abreviado como 8-oxoG), garantindo a integridade genômica (MICHAELS; MILLER, 1992). 
As espécies reativas de oxigênio (ROS) são produzidas a partir do próprio metabolismo celular, exposição a alguns agentes ambientais, incluindo oxidantes químicos, metais e radicais livres, e também a partir de radiações ionizantes (DAVID; O'SHEA; KUNDU, 2007). Dentre as consequências de danos no DNA originados por ROS, pode-se citar a modificação de bases nucleotídicas, danos nas moléculas de açúcar, quebras na cadeia do DNA, formação de sítios abásicos e ligação cruzada entre proteínas e DNA (FRIEDBERG et al., 2006).

Os nucleotídeos são considerados importantes alvos das ROS, e a guanina é mais susceptível à oxidação em relação aos demais nucleotídeos por apresentar menor potencial redox (NEELEY; ESSIGMANN, 2006). Um dos produtos mais estudados gerados a partir da oxidação da guanina é a 8-oxoG (BURROWS; MULLER, 1998), e esta lesão é utilizada como marcador celular indicativo de estresse oxidativo (KLAUNIG; KAMENDULIS, 2004). Bactérias que apresentam altos níveis de guanina e citosina no genoma são mais suscetíveis a estes danos, e portanto, mecanismos de reparo de 8-oxoG são considerados cruciais (KURTHKOTI et al., 2010). A formação desta lesão envolve primeiramente um ataque de radicais hidroxila $(\mathrm{OH} \bullet)$ no carbono 8 da guanina, que origina uma molécula intermediária de aduto $\mathrm{C} 8-\mathrm{OH}-$, que sofre reação de oxidação (perde um elétron (e-) e um próton $(\mathrm{H}+)$ ), e resulta na lesão 8-oxoG (Figura 4).

O dano 8-oxoG é considerado mutagênico por resultar em uma modificação no nucleotídeo guanina, o qual adquire a capacidade de se emparelhar tanto à base cognata, citosina, quanto à base não cognata, adenina, podendo resultar em lesões pré mutagênicas que geram eventos de transversão G:C $\rightarrow$ T:A (GROLLMAN; MORIYA, 1993). Diferentes DNA polimerases apresentam distintas preferências em inserir adenina ou citosina frente ao dano 8oxoG. DinB, uma DNA polimerase de translesão, é capaz de utilizar o nucleotídeo oxidado 8oxoG como substrato e pode pareá-lo frente a citosina ou preferencialmente frente a adenina (FOTI et al., 2012). A lesão 8-oxoG é caracterizada como pré-mutagênica e não letal, considerando que estes danos não bloqueiam a progressão das DNAs polimerases, e também não resultam em severas distorções estruturais na dupla hélice do DNA (WALLACE et al., 2002). Esta lesão oxidativa pode ser detectada através de diversos ensaios, incluindo cromatografia líquida de alta eficiência (HPLC) acoplada a detector eletroquímico ou com auxílio de métodos imunológicos (DELANEY et al., 2007). 


\section{Figura 4 - Representação esquemática da oxidação de guanina para 8-oxoguanina}

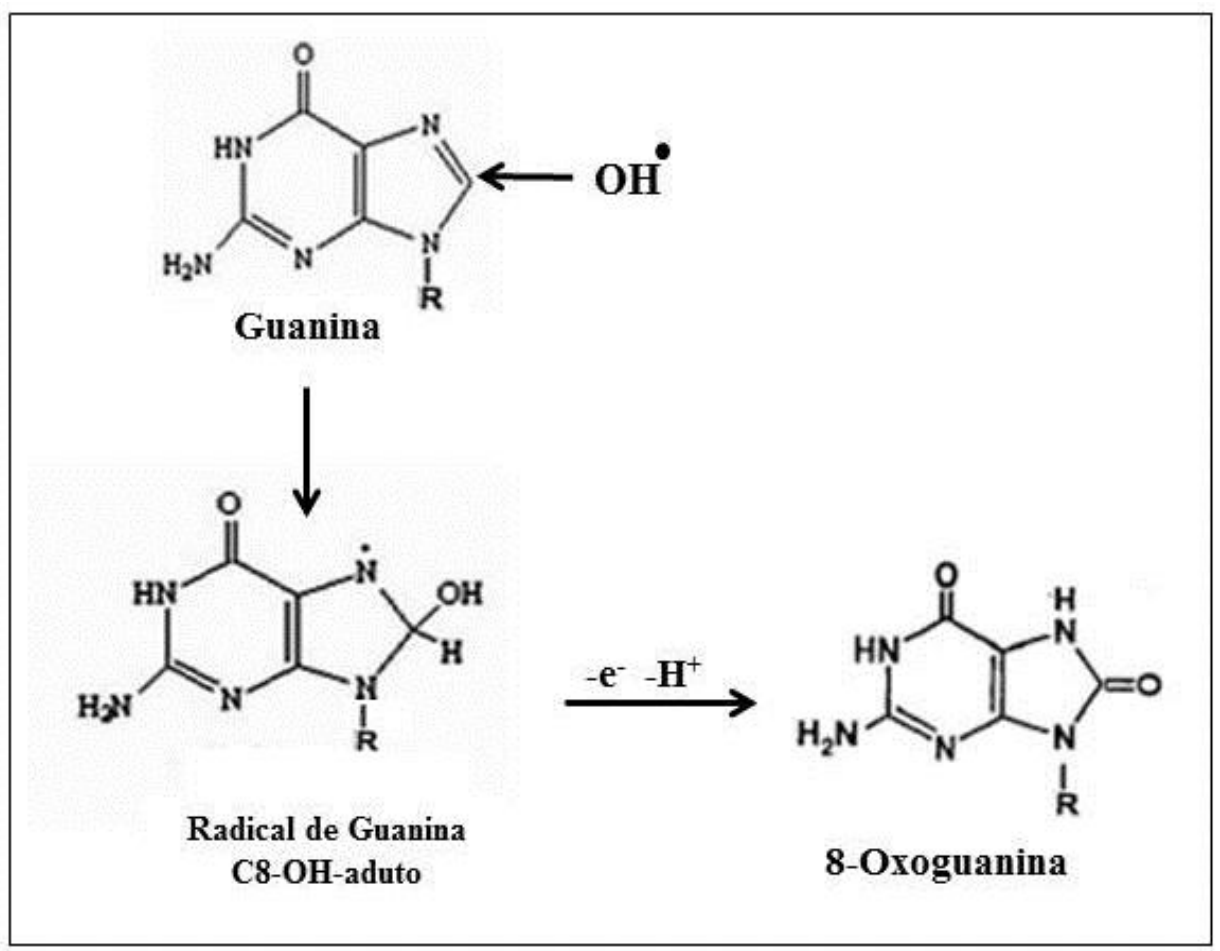

Radicais hidroxilas originados após estresse oxidativo celular podem reagir com o carbono 8 da guanina e resultar em um radical de guanina $\mathrm{C} 8$ - $\mathrm{OH}$-aduto que, então pode ser oxidado a 8oxoguanina.

Fonte: modificado de Lovell et al.(2007).

Em E. coli, o Sistema GO é composto pelas enzimas MutM, MutY e MutT, as quais atuam conjuntamente na prevenção dos efeitos mutagênicos gerados pela lesão 8-oxoG. As etapas envolvidas nesta via de reparo encontram-se esquematizadas na Figura 5. O primeiro passo deste mecanismo envolve a participação da glicosilase MutM (formamidopirimidina DNA-glicosilase - Fpg), que atua reconhecendo e excisando danos 8-oxoG quando estes se encontram pareados com o nucleotídeo citosina. Se este reparo não ocorrer antes do evento de replicação, o nucleotídeo adenina pode ser então inserido frente a 8-oxoG. Neste caso, a glicosilase MutY desempenha um importante papel por reconhecer e remover preferencialmente a adenina pareada a 8-oxoG. Além disto, para evitar o potencial mutagênico de adutos de 8-oxoG; a proteína MutT atua no pool de nucleotídeos, hidrolisando d(8-oxoGTP) à sua forma monofosfatada, que não pode ser incorporada durante a replicação, prevenindo com isto, a incorporação desta base oxidada no DNA (DELANEY et al., 2007; FRIEDBERG et al., 2006). 


\section{Figura 5 - Representação esquemática do sistema de reparo GO}

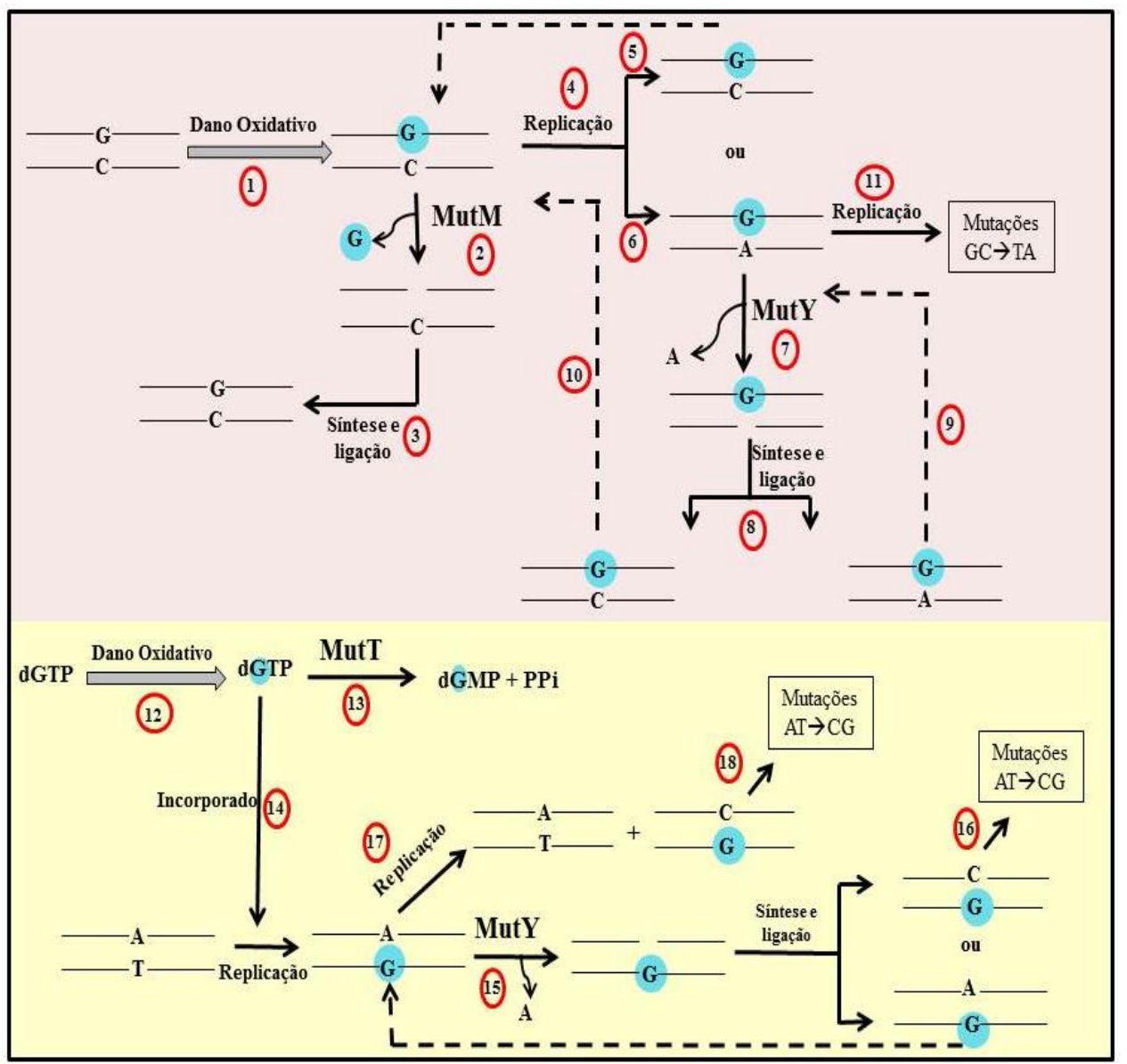

O estresse oxidativo pode resultar em danos do tipo 8-oxoG (1). A base oxidada 8-oxoG (círculos azuis) pode ser removida pela glicosilase MutM (2), e o reparo subsequente pela via BER pode restaurar o pareamento original GC (3). Caso eventos de replicação (4) ocorram antes do reparo por MutM, polimerases replicativas podem incorporar citosina (5) ou preferencialmente adenina(6) frente a 8-oxoG. A glicosilase MutY atua removendo a adenina pareada com 8-oxoG (7), gerando um gap que é preenchido pela via BER. A síntese de nucleotídeos durante o reparo pode restaurar o pareamento 8-oxoG:C (8), que pode ser corrigido por MutM (10). Este reparo pode também resultar no pareamento 8-oxoG:A (8), o qual pode ser alvo de MutY (9). Caso eventos de replicação ocorram antes do reparo por MutY, transversões GC $\rightarrow$ TA podem ser fixadas (11). O pool de nucleotídeos também pode ser alvo de ROS, e dGTPs oxidados podem resultar em 8-oxodGTPs (12). Os trifosfatos oxidados podem ser hidrolisados por mutT a monofosfato (8-oxodGMP) (13), ou podem ser incorporados frente a adenina (14). MutY pode atuar removendo a adenina (15) pareada a 8-oxoG e favorecer a fixação da mutação AT $\rightarrow C G$ (16) Eventos de replicação podem ocorrer antes do reparo por MutY (17), o que também favorece mutações AT $\rightarrow$ CG (18).

Fonte: modificado de Kurthkoti et al. (2010).

\subsubsection{Síntese translesão}

Em princípio, a maioria dos danos no DNA é corrigida por mecanismos de reparo de excisão, porém quando a forquilha de replicação atinge a área lesada, estes mecanismos 
perdem a capacidade de atuação. Neste caso, o mecanismo de tolerância a danos denominado síntese translesão (TLS) é extremamente importante por promover o desbloqueio da replicação e garantir a sobrevivência celular (INDIANI; O`DONNELL, 2013). A via TLS envolve a participação de polimerases específicas denominadas DNA polimerases da família Y ou TLS-DNA polimerases, que são capazes de sintetizar DNA frente a lesões no DNA, como por exemplo, dímeros de pirimidinas. Estas enzimas são pouco processivas, não apresentam atividade exonucleolítica revisora 3 '- 5', e podem resultar em altas taxas de erro, promovendo um aumento da mutagênese durante a replicação (FRIEDBERG et al., 2006). Evidências vêm sendo acumuladas demonstrando que as bactérias expressam estas enzimas em condições diversas, tais como entrada em fase estacionária e exposição a antibióticos, potencialmente modulando suas taxas de mutação (GALHARDO; HASTINGS; ROSENBERG, 2007). Desta forma, além de atuarem promovendo a sobrevivência celular, estas enzimas parecem ser fundamentais na geração de variabilidade genética, modulação da evolução e disseminação de resistência a drogas (FUCHS; FUJII, 2013).

Em E.coli, a via TLS é dependente das DNA polimerases IV e V, codificadas pelos genes $\operatorname{din} B$ e $u m u D C$, respectivamente (TANG et al., 1999; WAGNER et al., 1999). A polimerase V é expressa tardiamente após a indução do sistema SOS, e está associada com a maior parte da mutagênese dependente da via TLS (INDIANI; O`DONNELL, 2013). A atividade da polimerase $\mathrm{V}$ é dependente de RecA, que após formar filamentos nucleoprotéicos no ssDNA e se tornar ativa $\left(\operatorname{Rec} A^{*}\right)$, promove a clivagem de UmuD (resulta em UmuD`), o qual se associa com UmuC formando o complexo $\mathrm{UmuD}_{2}{ }_{2} \mathrm{C}$. As proteínas UmuC e UmuD` inibem o processo de recombinação homóloga, devido a interação direta entre $\mathrm{UmuD}_{2}{ }_{2} \mathrm{C}$ e os filamentos nucleoproteicos RecA/ssDNA (REHRAUER et al., 1996; SZPILEWSKA et al., 1995). A forma não clivada $\mathrm{UmuD}_{2}$ atua na prevenção de mutagêneses através de UmuC ou DinB, e a forma clivada UmuD` ${ }_{2}$ favorece eventos mutagênicos via Pol V (OLLIVIERRE; BEUNING, 2010). O processo de síntese translesão desempenhado pela DNA polimerase V em geral resulta em mutações numa frequência alta de $10^{-3}$ a $10^{-4}$ (TANG et al., 2000). A atividade desta polimerase é dependente de RecA e também ATP (FUJII; GASSER; FUCHS, 2004). Além disto, a proteína SSB e a subunidade $\beta$ da DNA polimerase III podem também atuar aumentando a eficiência da síntese translesão (FUJII; GASSER; FUCHS, 2004; PHAM et al., 2002). 
De acordo com o modelo descrito por Fuchs e Fujii (2013) o processo de síntese translesão em $E$. coli envolve basicamente as seguintes etapas: DNA polimerase replicativa (DNA polimerase III) ao encontrar uma lesão que bloqueia a replicação irá se dissociar da forquilha de replicação e do DNA; TLS-DNA polimerase se liga nesta região e sintetiza DNA ao longo do trecho de DNA contendo o dano; TLS-DNA polimerase se dissocia do complexo e a DNA polimerase replicativa se liga e retoma a síntese de DNA (Figura 6). Estudos demonstraram também que a interação entre DNA polimerase IV e V com o grampo $\beta$ (“ $\beta$ clamp") no DNA é essencial para a atividade de síntese translesão desempenhada por estas enzimas (BECHEREL; FUCHS; WAGNER, 2002).

Figura 6 - Representação esquemática da síntese translesão em procariotos.

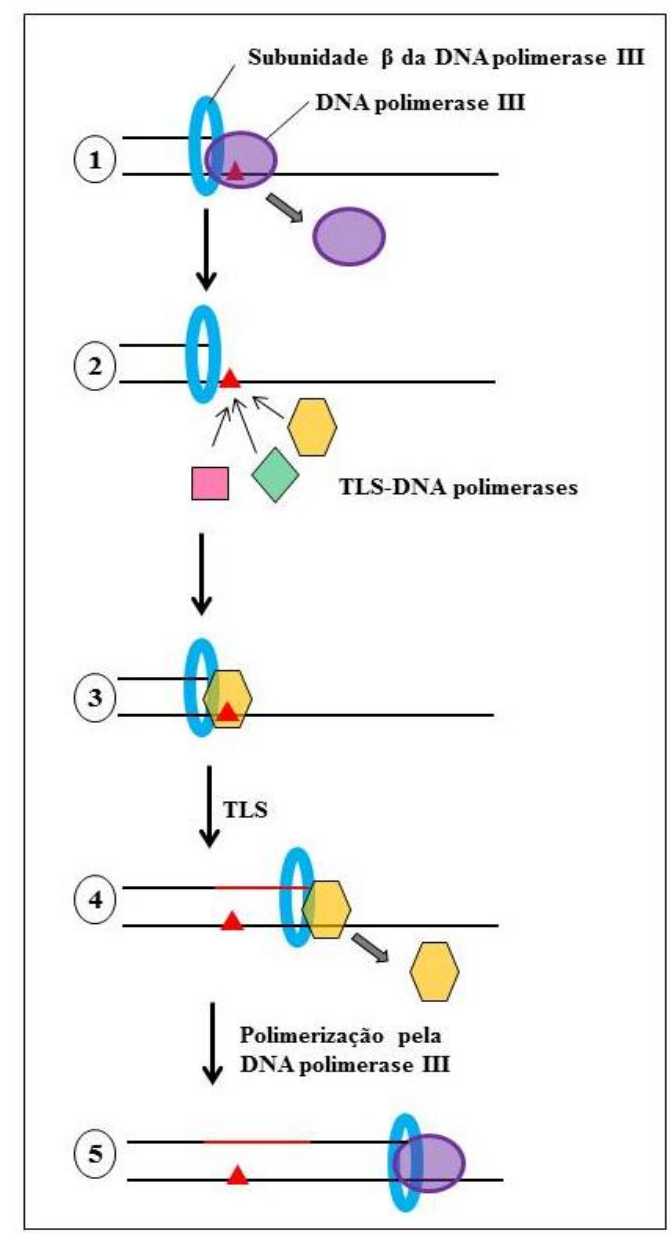

1) A DNA polimerase III ao encontrar um dano que bloqueia a replicação não poderá sintetizar DNA frente a este trecho, e irá se dissociar da forquilha de replicação. 2 e 3) DNAs polimerases alternativas capazes de realizar síntese translesão são recrutadas, se ligam e sintetizam DNA ao longo deste trecho. 4) Após a síntese de DNA frente ao dano é finalizada, a TLS-DNA polimerase se dissocia. 5) A polimerase replicativa retoma a síntese de DNA.

Fonte: modificado de Fuchs e Fujii (2013). 
Apesar da DNA polimerase II não ser incluída no grupo das polimerases da família Y, estudos comprovaram que esta enzima é capaz de realizar síntese translesão frente a sítios AP (Paz-Elizur et al., 1996), à base alquilada 3, $N^{4}$-etenocitosina (AL MAMUN; HUMAYUN, 2006), e também frente a algumas ligações cruzadas intercadeia (BERARDINI; FOSTER; LOECHLER, 1999). Napolitano e colaboradores (2000) demostraram também que dependendo da natureza do dano no DNA e também da sequência nucleotídica afetada, as três DNA polimerases SOS-dependentes, PolIV, PolV e Pol II, podem estar envolvidas com a síntese translesão. Além disto, estudos descrevem também o envolvimento da DNA polimerase I na síntese translesão frente a danos do tipo ligação cruzada induzidos por psoraleno (ZIETLOW; BESSHO, 2008).

\subsubsection{Reparo de ligações cruzadas intercadeia no DNA}

As ligações cruzadas (ICLs) afetam o metabolismo do DNA e são consideradas muito deletérias e citotóxicas para as células por bloquearem processos essenciais de replicação, transcrição e reparação, uma vez que impedem a separação das duas fitas do DNA. Por isso, mecanismos celulares para detecção e remoção de ICLs são cruciais para a sobrevivência celular (SCHÄRER, 2010).O reparo de ICLs em E. coli é bem caracterizado e pode envolver dois mecanismos de reparo distintos, os quais demandam a atividade concomitante de diferentes vias de reparo de DNA. As etapas envolvidas neste reparo encontram-se esquematizadas na Figura 7.

O primeiro mecanismo envolve a participação da via NER associada com eventos de recombinação homóloga. Neste mecanismo, o complexo formado pelas endonucleases $\operatorname{Uvr}(\mathrm{A})_{2} \mathrm{BC}$ atua primeiramente excisando o DNA em ambos os lados que margeiam a lesão. Em seguida, a DNA polimerase I, que apresenta atividade exonucleolítica 5' $\rightarrow$ 3', atua nesta região e resulta na formação de DNA fita simples (ssDNA). RecA reconhece e se liga na região ssDNA, e promove a recombinação homóloga entre DNA livre de dano e DNA contendo ICL. Em seguida, a DNA polimerase I catalisa a síntese de DNA ao longo da região com ICL, e Uvr(A) ${ }_{2} \mathrm{BC}$ agem excisando o fragmento de DNA contendo a lesão. Por último, a DNA polimerase I sintetiza DNA na lacuna presente na fita de DNA (MCVEY, 2010).

$\mathrm{Na}$ ausência de sequências homólogas de DNA ou proteína RecA, um segundo mecanismo de reparo de ICLs é empregado em E.coli, sendo este dependente das vias NER e TLS. De fato, a reparação independente de homologia representa um papel importante em 
bactérias, já que estes organismos apresentam genomas pequenos e haplóides, e a falta de fragmentos de DNA como moldes, pode inviabilizar a recombinação por homologia (HINZ, 2010). Este segundo mecanismo envolve a participação inicial do complexo enzimático $\operatorname{Uvr}(\mathrm{A})_{2} \mathrm{BC}$, que promove uma incisão no DNA em ambos os lados que margeiam a lesão ICL. Em seguida, DNAs polimerases capazes de realizar síntese translesão atuam sintetizando DNA ao longo do fragmento contendo o dano ICL. Posteriormente, o complexo endonucleásico $\operatorname{Uvr}(\mathrm{A})_{2} \mathrm{~B}$ promove novamente uma incisão em ambos os lados do segmento com ICL, e a DNA polimerase I atua incorporando nucleotídeos na lacuna remanescente na fita de DNA, completando o processo de reparo (SCHÄRER, 2010).

Figura 7 - Representação esquemática dos mecanismos envolvidos no reparo de ligações cruzadas intercadeia em E.coli

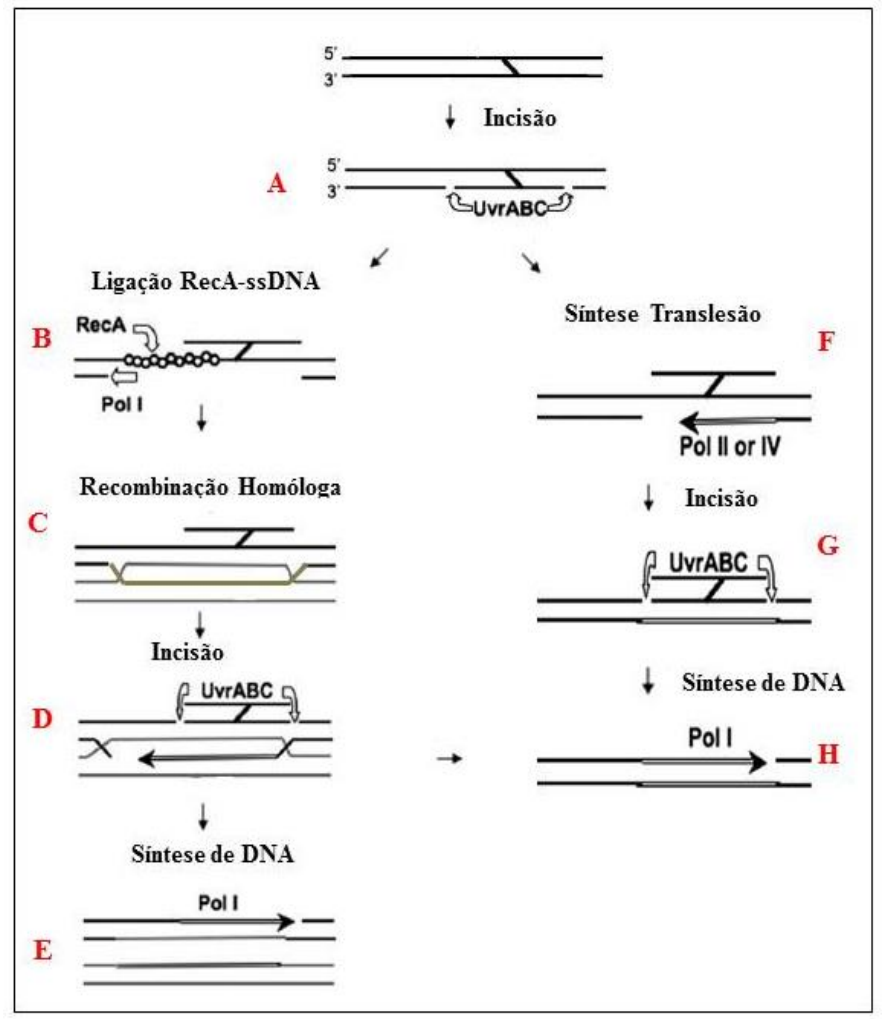

(A) $\operatorname{Uvr}(\mathrm{A})_{2} \mathrm{BC}$ incisa o segmento de DNA em ambos os lados da ICL. (B) A atividade exonucleolítica de PolI é responsável por formar um região ssDNA próximo ao ICL que é reconhecida e coberta por RecA. (C)RecA promove a invasão da fita e recombinação homóloga, seguida pela síntese de DNA opostamente ao ICL. As junções de Holliday são originadas e resolvidas nesta etapa. (D) Uvr(A) ${ }_{2} \mathrm{BC}$ realiza outra incisão em ambos os lados da região flanqueadora da ICL, liberando o segmento que contem este dano. (E e H) Síntese de DNA pela Pol I finaliza o processo de reparo. (F) Na via de reparo de ICL independente de recombinação homóloga, DNAs polimerases promovem a síntese translesão frente à ICL. $(\mathrm{G}) \operatorname{Uvr}(\mathrm{A})_{2} \mathrm{BC}$ realiza incisão nas regiões que flanqueiam o dano, e libera o segmento contendo a ICL.

Fonte: modificado de Hinz (2010) 
Diferenças estruturais nas ICLs geradas podem resultar em distintos mecanismos para reparar estas lesões. Estudo realizado por Berardini, Foster e Loechler (1999) mostrou que ICLs originadas por tratamento com psoralenos não são reparadas pelo mecanismo dependente de TLS. Além disto, diferentes ICLs podem requerer a participação de distintas DNA polimerases da família Y no reparo destes danos. Foi demonstrado que distintas DNA polimerases estão envolvidas na síntese translesão de ICLs, e que a estrutura destas lesões afetam a eficiência da translesão (SCHÄRER, 2010). Ademais, em E.coli, ICLs entre guaninas $\left(\mathrm{N}^{2}-\mathrm{N}^{2}\right)$ não sofrem síntese translesão pela DNA polimerase II (PolII), mas sim pela DNA polimerase IV (PolIV) (KUMARI, et al., 2008). Os reparos de ICLs envolvendo a síntese translesão por Pol II e Pol IV não são propensos a erros, ou seja, mutações não são incorporadas durante o processo de reparo (SCHÄRER, 2010). Apesar de pouco eficiente, a polimerase I também foi capaz de realizar síntese translesão frente a danos ICLs provocados por psoraleno (ZIETLOW; BESSHO, 2008).

\subsection{O regulon SOS}

O sistema SOS está presente em procariotos e está envolvido no reparo e tolerância a danos no DNA, na regulação da divisão celular e na manutenção da integridade da forquilha de replicação. Esse sistema foi melhor caracterizado em Escherichia coli, e é responsável por lidar com distintas situações de danos e promover respostas adequadas nas células (CROWLEY; COURCELLE, 2002; FRIEDBERG et al., 2006).

A regulação deste sistema em resposta a danos no DNA é dependente dos produtos dos genes recA e lexA. A Figura 8 esquematiza os eventos envolvidos na indução desta resposta. Em um estado celular não induzido, os genes pertencentes a esse sistema são reprimidos pela proteína LexA, a qual interage com sequências regulatórias específicas dos respectivos genes, denominadas "caixa SOS” (FRIEDBERG et al., 2006). Estas sequências operadoras se localizam em proximidade ou sobrepostas ao sítio de ligação da RNA polimerase e, portanto, a ligação de LexA a este trecho afeta o início do processo de transcrição (revisto por ERILL; CAMPOY; BARBÉ, 2007). O sistema SOS é induzido pelo acúmulo de trechos de fitas simples no DNA (ssDNA), que são formados por bloqueio da replicação cromossomal e problemas na recombinação (BUTALA; ZGUR-BERTOK; BUSBY, 2009). Após se ligar a íons de $\mathrm{Mg}^{2+}$ e em presença de ATP, a proteína RecA 
interage com regiões ssDNA e se torna ativa (RecA*), formando fragmentos de nucleoproteínas (KOVACIC et al., 2013). Nesta forma, RecA* se liga ao repressor LexA, promovendo a auto-clivagem deste entre a ligação Ala $^{84}$-Gly ${ }^{85}$ desta proteína. A proteína RecA* atua ativando o sistema SOS por diminuir os níveis intracelulares de moléculas de LexA intactas, e com isto, promove a dissociação deste repressor de sequências operadoras no DNA (BUTALA et al., 2011). Depois de clivada, LexA perde a capacidade de se ligar às sequências operadoras (KOVACIC et al., 2013), e a repressão dos genes do regulon SOS é interrompida. A transcrição destes genes resulta na produção de enzimas específicas necessárias para proteção contra os danos celulares (COURCELLE et al., 2001).

À medida que os danos no DNA são reparados ou tolerados, o nível do sinal indutor diminui, acarretando na diminuição da conversão da proteína RecA em RecA*. Com isso, tem-se novamente um acúmulo da proteína LexA intacta, a qual passa a se ligar aos operadores, resultando na repressão transcricional de genes do sistema SOS.

A parada da forquilha de replicação é considerada um dos principais sinais responsáveis pela indução da resposta SOS, e culmina, em princípio, com a indução de alguns genes SOS (como recA e $s s b$ ), que atuam na estabilização e proteção da forquilha. Em seguida, um segundo grupo de genes é induzido para lidar com os danos no DNA através de mecanismos específicos de reparo, incluindo, por exemplo: $u v r A, u v r B, \operatorname{ruvAB}, u v r D$, $\operatorname{recN}$, $y d j Q$ (WALKER, 1984). Em situações onde as lesões não podem ser reparadas por estes mecanismos, o sistema SOS atua regulando a expressão de polimerases especiais responsáveis pela síntese de DNA frente a esses danos (Descritas na seção 1.1.4).

A estabilização e desmontagem dos filamentos nucleoprotéicos RecA-ssDNA são regulados pelos genes dinI e $\operatorname{rec} X$, respectivamente (RENZETTE; GUMLAW; SANDLER, 2007). Esta regulação garante flexibilidade nos processos de "montagem" e "desmontagem" de filamentos de RecA, que são extremamente importantes para o equilíbrio de algumas funções celulares, incluindo recombinação celular, indução do regulon SOS e mutagênese SOS-dependente (SCHLACHER; GOODMAN, 2007).

Os genes recA e lexA são controlados por LexA, porém são expressos em níveis significativos mesmo em células em estado não induzido (SASSANFAR; ROBERTS, 1990). A expressão basal de genes SOS em condições de não indução é mantida pela sequência imperfeita do sítio operador ou devido a promotores alternativos (FERNÁNDEZ DE HENESTROSA et al., 2000). Esses níveis basais de LexA e RecA são justificáveis pelo seu 
papel importante no controle da resposta SOS. Além disso, a proteína RecA também está envolvida em diversos processos celulares, como: recombinação homóloga, ligação ao DNA, hidrólise de ATP e indução de autoclivagem (KOWALCZYKOWSKI et al., 1994).

\section{Figura 8 - Representação esquemática da indução da resposta SOS}

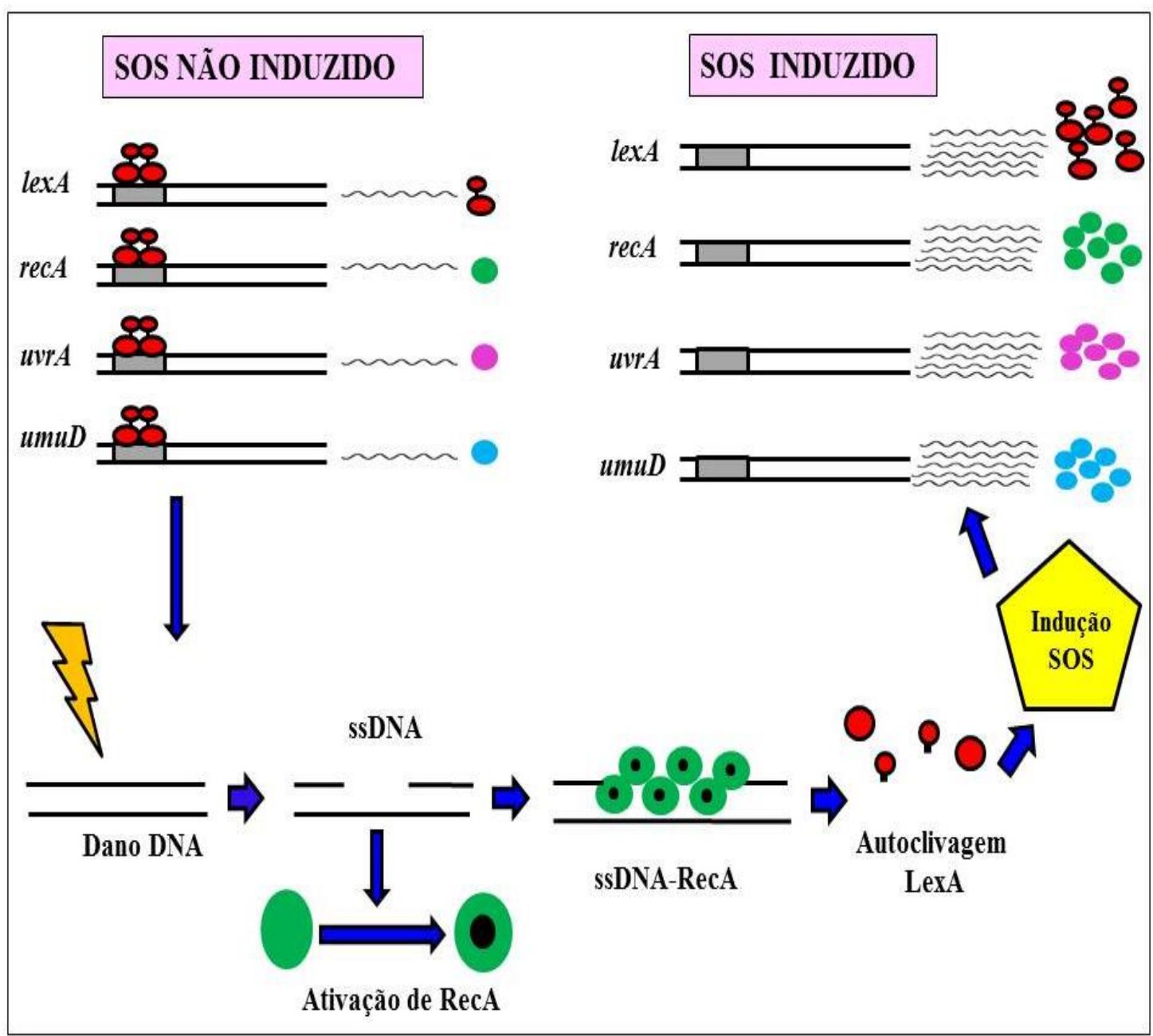

$\mathrm{Na}$ ausência de indução do regulon SOS, LexA se mantem ligada a sequências operadoras dos genes regulados pela resposta SOS, reprimindo-os. A presença de danos no DNA resultam na formação de trechos de fitas simples (ssDNA) na molécula de DNA. A proteína RecA reconhece e se liga nestas regiões, torna-se ativa, e promove a auto clivagem de LexA. A forma clivada de LexA não se liga às caixas SOS, e os genes SOS deixam de ser reprimidos e atuam codificando proteínas que lidam com as lesões presentes no DNA.

\subsubsection{Sistema SOS: E. coli versus $C$. crescentus}

O regulon SOS foi extensamente estudado em E. coli. Através de análise genética tradicional, a maioria dos genes pertencentes a este regulon foi identificada e caracterizada, ao 
longo de mais de quarenta anos de estudo. Mais recentemente, análises realizadas in silico e análises de microarranjos de DNA colaboraram na identificação de genes adicionais pertencentes a este regulon neste organismo (COURCELLE et al., 2001; FERNÁNDEZ DE HENESTROSA et al., 2000).

Atualmente, mais de quarenta genes foram descritos como pertencentes ao regulon SOS de E.coli, e a caracterização deste regulon em outras espécies apresentou um paradigma fascinante. Os genes induzidos pelo regulon SOS apresentam alguns aspectos funcionais que variam muito entre as diferentes espécies, enquanto outros são relativamente específicos para determinados grupos bacterianos (revisto por ERILL; CAMPOY; BARBÉ, 2007). Portanto, a regulação dos genes SOS descrita para E. coli não deve ser considerada como modelo universal para outras bactérias.

Os genes recA e lexA são extensamente conservados em genomas bacterianos, sendo raras as exceções de espécies que não apresentam estes genes. Desta forma, a imensa maioria das espécies parece possuir um grupo de genes regulados em resposta a lesões no DNA por este sistema. Entretanto, todos os outros aspectos da resposta SOS parecem divergir imensamente em diferentes espécies (revisto por ERILL; CAMPOY; BARBÉ, 2007). Primeiramente, a sequência operadora (caixa SOS) reconhecida por LexA varia enormemente, sendo apenas razoavelmente conservada em grupos filogeneticamente muito próximos. Além disso, o conjunto de genes regulados também varia consideravelmente, de forma que vários genes pertencentes a este regulon em $E$. coli não são regulados pelo SOS em outras bactérias, ou mesmo estão ausentes de seus genomas. O inverso também é verdadeiro. Genes identificados como pertencentes a este regulon em outras bactérias, alguns deles bem conservados, estão ausentes do genoma de E. coli. Por outro lado, alguns temas parecem ser constantes dentro do regulon SOS em diferentes modelos, tais como a regulação de diversos genes de reparo de DNA e recombinação, a regulação de genes que inibem a divisão celular, e a regulação de DNA polimerases envolvidas em síntese translesão. Logo, a resposta SOS em diferentes espécies apresenta uma enorme divergência, e por isso, diversos genes controlados pelo regulon SOS em outros modelos bacterianos devem ser melhor caracterizados e identificados (KAWAI; MORIYA; OGASAWARA, 2003).

Neste trabalho, utilizamos a bactéria Caulobacter crescentus como modelo para estudos do regulon SOS, dando continuidade a uma linha de pesquisa já desenvolvida por nosso grupo (DA ROCHA et al., 2008; GALHARDO et al., 2005). C. crescentus é uma alfa- 
proteobactéria, não patogênica, que vive em diversos ambientes aquáticos e também no solo. Esta bactéria apresenta um ciclo assimétrico de divisão celular e também um ciclo de vida dimórfico, já que a divisão celular resulta em duas células filhas morfologicamente distintas: uma célula móvel e uma célula séssil ("célula talo"). A forma celular móvel não é capaz de iniciar o processo de replicação do DNA, e para isto, necessita se diferenciar na célula séssil para garantir que ocorra divisão celular (revisto por TSOKOS; LAUB, 2012).

C. crescentus vem emergindo como um interessante modelo alternativo para estudos de mecanismos de reparo de DNA e mutagênese. Dentre alguns fatores que favorecem a utilização desta bactéria como modelo, podemos incluir: disponibilidade da completa sequência do seu genoma, facilidade de cultivo e disponibilidade de uma grande gama de ferramentas para análise genética.

Nosso grupo já conseguiu significativos avanços no estudo da resposta SOS em $C$. crescentus. As polimerases codificadas pelo operon umuDC em E. coli são consideradas as mais importantes para a replicação frente a lesões induzidas por luz UV (NOHMI, 2006). No genoma de $C$. crescentus, no entanto, não foram identificados homólogos de umuDC, o mesmo ocorrendo para a maioria dos genomas bacterianos. Em C. crescentus, foi caracterizado o operon imuAB dnaE2 (GALHARDO et al., 2005), que assim como o operon $u m u D C$ em E. coli, é regulado pelo sistema SOS. A mutagênese induzida por mitomicina $C$ se mostrou completamente dependente da atividade destes genes, enquanto que a mutagênese induzida por luz UV se mostrou apenas parcialmente dependente de imuAB dnaE2 (GALHARDO et al., 2005). Desta forma, estes genes codificam proteínas envolvidas em síntese translesão. Entretanto, pelo menos para lesões causadas por luz ultravioleta, outros genes também podem estar envolvidos no processo de síntese translesão nesta bactéria.

Através de uma análise de bioinformática, 37 genes componentes do regulon SOS de C. crescentus foram identificados por nosso grupo (Tabela 2) (DA ROCHA et al., 2008). Além disto, ensaios de microarranjos realizados em C. crescentus posteriormente por Modell, Hopkins e Laub (2011), demonstram que estes mesmos genes são regulados em resposta a danos no DNA. Além do operon iтиAB dnaE2 descrito acima, outros genes claramente envolvidos em reparo de DNA fazem parte deste regulon, tais como $u v r A, u v r B$ e recA. Entretanto, a maioria dos genes regulados codificam proteínas de função desconhecida. É interessante notar que a maioria dos genes mais fortemente induzidos pela resposta SOS são 
precisamente genes de função desconhecida (DA ROCHA et al., 2008). Portanto, estes devem possuir papel relevante na fisiologia celular após a introdução de lesões no DNA.

Um exemplo que ilustra este fato é o checkpoint de filamentação em C. crescentus. Em situações de perturbações, não favoráveis à sobrevivência celular, o sistema SOS pode agir bloqueando a divisão celular. Este mecanismo de controle é considerado por alguns pesquisadores como um exemplo de checkpoint bacteriano (AUTRET et al., 1997). Em E. coli este mecanismo é mediado pela proteína SulA, membro do regulon de LexA. Em situações em que o sistema SOS é induzido, a transcrição de sulA é altamente induzida (COURCELLE et al., 2001). Esta proteína interage com FtsZ, inibindo a formação do anel no septo divisional (MUKHERJEE; CAO; LUTKENHAUS, 1998). Isto resulta em um crescimento celular sem que a divisão celular seja estabelecida, originando células com aspecto filamentoso (HUISMANM; D’ARI; GOTTESMAN, 1984).

Erill e colaboradores (2006) demonstraram que a maioria das bactérias não possuem em seus genomas homólogos de sulA, e que a presença deste gene está restrita a organismos mais próximos filogeneticamente a E. coli. Em Bacillus subtilis, por exemplo, a proteína YneA, não homóloga à SulA, desempenha a mesma função que SulA, atuando como um supressor da divisão celular durante a resposta SOS (KAWAI; MORIYA; OGASAWARA, 2003). Um estudo desenvolvido em $C$. crescentus demonstrou que a cepa deficiente no gene lexA apresenta um fenótipo de células filamentosas (DA ROCHA et al., 2008). Como homólogos de sulA não estão presentes nestes organismos, foi sugerida a presença de outros mecanismos distintos de bloqueio da divisão celular, os quais podem ser mediados pelo sistema SOS, responsáveis por este fenótipo.

De fato, recentemente foi identificado o gene (CC_1927) responsável por este checkpoint em $C$. crescentus (MODELL; HOPKINS; LAUB, 2011), sendo este um dos genes de função desconhecida previamente identificados como regulado pelo SOS em nosso trabalho (Tabela 2) (DA ROCHA et al., 2008). Da mesma maneira, é nossa expectativa que outros genes pertencentes a este regulon também possuam papéis relevantes na resposta SOS nesta bactéria. 
Tabela 2 - Genes identificados por análise in silico como componentes do regulon SOS em C. crescentus

(continua)

\begin{tabular}{|c|c|c|}
\hline ORF & Nome do gene/Anotação em C. crescentus CB15 & $\begin{array}{l}\text { Expressão Relativa } \\
\text { (lexA/cepa selvagem) }\end{array}$ \\
\hline CC_1902 & $\operatorname{lexA}$ & $43.2 \pm 9.3$ \\
\hline CC_0627 & Proteína hipotética & $40.3 \pm 11.8$ \\
\hline CC_3467 & Proteína hipotética conservada & $37.5 \pm 10.5$ \\
\hline CC_3518 & Proteína hipotética conservada & $27.4 \pm 4.8$ \\
\hline CC_2332 & Proteína hipotética conservada & $18.8 \pm 6.8$ \\
\hline CC_2333 & Proteína relacionada à uracila glicosilase & $8.3 \pm 1.2$ \\
\hline CC_1926 & dnaE/DNA polimerase III, subunidade alfa & $1.6 \pm 0.6$ \\
\hline CC_1927 & Proteína hipotética & $17.7 \pm 6.2$ \\
\hline CC_3213 & $\begin{array}{l}\text { imuA (inducible mutagenesis protein } \mathrm{A} \text { ), em operon } \\
\text { com ImuB (DNA polimerase família Y) e DnaE2 }\end{array}$ & $16.2 \pm 4.7$ \\
\hline CC_2272 & Proteína da família da Endonuclease III & $14.7 \pm 3.1$ \\
\hline CC_3424 & Proteína hipotética conservada & $13.62 \pm 5.5$ \\
\hline CC_1330 & Proteína com domínio radical SAM & $11.7 \pm 3$ \\
\hline CC_1054 & Proteína hipotética & $11.3 \pm 5.5$ \\
\hline CC_2040 & $\begin{array}{l}\text { RNA helicase dependente de ATP, família } \\
\text { DEAD/DEAH }\end{array}$ & $9.1 \pm 3.4$ \\
\hline CC_1087 & recA/recombinação de DNA & $9.0 \pm 1.5$ \\
\hline CC_2879 & Proteína hipotética & $8.0 \pm 1.6$ \\
\hline CC_2880 & Proteína hipotética & $9.74 \pm 3.7$ \\
\hline CC_2881 & uvrC/exonuclease $\mathrm{ABC}$, subunidade $\mathrm{C}$ & $1.7 \pm 0.3$ \\
\hline CC_3038 & Proteína hipotética conservada & $5.3 \pm 0.8$ \\
\hline CC_3037 & Proteína hipotética conservada & $7.7 \pm 1.9$ \\
\hline CC_3036 & Proteína hipotética & $7.3 \pm 1.2$ \\
\hline CC_3039 & Proteína hipotética & $4.4 \pm 0.2$ \\
\hline CC_3356 & Proteína hipotética & $6.3 \pm 2.5$ \\
\hline $\mathrm{CC}_{-} 1531$ & Proteína hipotética & $5.9 \pm 1.1$ \\
\hline CC_1983 & recN & $5.6 \pm 1.6$ \\
\hline
\end{tabular}


Tabela 2 - Genes identificados por análise in silico como componentes do regulon SOS em C. crescentus

(continuação)

\begin{tabular}{lcc}
\hline ORF & Nome do gene/Anotação em C. crescentus CB15 & $\begin{array}{c}\text { Expressão Relativa } \\
\text { (lexA/cepa selvagem) }\end{array}$ \\
\hline CC_0140 & comM/proteína de competência ComM & $4.7 \pm 0.1$ \\
CC_0383 & Proteína hipotética & $5.0 \pm 2.7$ \\
CC_3238 & ruvC & $5.1 \pm 1.9$ \\
CC_3237 & ruvA & $5.0 \pm 0.8$ \\
CC_3236 & ruvB & $3.4 \pm 0.4$ \\
CC_3225 & Caixa sensora histidina quinase/regulador de resposta & $4.8 \pm 1.9$ \\
CC_0382 & tag/ DNA- metiladenina glicosilase I & $3.4 \pm 1.2$ \\
CC_2590 & uvrA/ exonuclease ABC, subunidade A & $3.5 \pm 1.0$ \\
CC_1532 & Proteína hipotética conservada & $3.1 \pm 0.7$ \\
CC_3515 & Proteína hipotética conservada & $3.1 \pm 0.6$ \\
CC_1665 & dnaB/DNA helicase replicativa & $0.3 \pm 0.1$ \\
CC_2433 & Proteína hipotética conservada & $0.1 \pm 0.0$ \\
\hline
\end{tabular}

Fonte: modificado de Da Rocha et al. (2008).

Neste trabalho, buscamos caracterizar funcionalmente os genes CC_0627 (CCNA_00663), CC_3467 (CCNA_03580), CC_3424 (CCNA_03537) e CC_2040 (CCNA_02121). Conforme descrito por Da Rocha e colaboradores (2008), estes genes são fortemente regulados pelo sistema SOS. Os fatores de indução (nível de expressão relativa comparando células que expressam o regulon SOS constitutivamente com células selvagens não tratadas com agentes genotóxicos) observados em nossos estudos anteriores são: gene CC_0627, 40 vezes; CC_3467, 37 vezes; CC_3424, 13 vezes e CC_2040, 9 vezes (Tabela 2). Além disso, estes genes apresentam algumas características que justificam sua escolha, as quais serão descritas abaixo.

O gene CC_0627 não possui homólogos no banco de dados. Análises de domínios revelam que a proteína codificada apresenta alguma similaridade com endonucleases. Este gene foi recentemente caracterizado por outro grupo que o denominou bapE. Estes pesquisadores mostraram que a proteína BapE apresenta atividade de endonucleases in vitro e 
apresenta função em processos de morte celular programada em bactérias (BOS; YAKHNINA; GITAI Z, 2012). O gene CC_3467 é bastante conservado em várias alfaproteobactérias, e análise de domínios revela similaridade com endonucleases (Apêndice Figura A4). O gene CC_3424 é extremamente conservado em várias espécies de bactérias, e apresenta domínios protéicos similares à glioxalases e dioxigenases, que estão envolvidas com resistência a antibióticos, em particular à bleomicina (Apêndice - Figura A5). O gene CC_2040 codifica uma proteína similar a proteínas da família Lhr, que são helicases de DNA e RNA ATP-dependentes.

\subsection{Antibióticos, danos no DNA e a resposta SOS}

Além de agentes que causam danos diretos ao DNA, a resposta SOS é ativada por diversos outros estresses ambientais, tais como alterações no $\mathrm{pH}$, aumento na pressão, e exposição à cromato (revisto por ERILL; CAMPOY; BARBÉ, 2007). O exato mecanismo através do qual a resposta SOS é induzida por estes agentes, ou seja, os mecanismos através dos quais estes formam sinal indutor do SOS (trechos de DNA em simples fita), ainda é tema de discussão. Dentre os diversos agentes capazes de induzir a resposta SOS em bactérias, especial atenção tem sido dirigida aos antibóticos.

A indução do SOS por antibióticos da classe das quinolonas, tais como o ácido nalidíxico e seus derviados, já é bem conhecida, visto que estas drogas agem justamente sobre o metabolismo de DNA bacteriano, atuando como inibidoras da DNA girase, sendo promotoras de quebras duplas no DNA que resultam no bloqueio da replicação (DRLICA; ZHAO, 1997). Entretanto, outras classes de antibióticos, em especial beta-lactâmicos, também parecem induzir a resposta SOS em várias espécies de bactérias (revisto por ERILL; CAMPOY; BARBÉ, 2007), embora seu mecanismo de ação (inibição da síntese da parede celular) não possua nenhuma relação óbvia com o metabolismo de DNA. Em E. coli, foi relatada a indução da resposta SOS por beta-lactâmicos, mediada pelo sistema de transdução de sinal de dois componentes $d p i B A$, que segundo o modelo proposto, inibe a replicação, induzindo o SOS (MILLER et al., 2004). Estes autores propõem que a indução da resposta SOS é um mecanismo protetor, pois reduz a velocidade de crescimento e inibe a divisão celular, protegendo a célula contra drogas que requerem metabolismo ativo para exercer seus efeitos tóxicos, como é o caso desta classe de antibóticos. Além disto, um estudo realizado 
recentemente por Plata e colaboradores (2013) demonstrou que antibióticos beta-lactâmicos também induzem a resposta SOS em Staphylococcus aureus. Segundo estes pesquisadores, antibióticos beta-lactâmicos atuam interferindo nas funções da protéina PBP1, o que resultaria na parada da divisão celular e desencadeamento da resposta SOS.

Kohanski, Depristo e Collins (2010) demostraram também que os antibióticos betalactâmicos causam lesões oxidativas no DNA, induzindo mutagênese. A indução do regulon SOS por antibióticos varia entre diferentes microorganismos e antibióticos. Antibióticos aminoglicosídeos, tetraciclina e rifampicina, por exemplo, são indutores da resposta SOS em Vibrio cholerae, mas não induzem esta resposta em E. coli (BAHAROGLU; MAZEL, 2011).

A resposta SOS invariavelmente controla DNA polimerases de baixa fidelidade, envolvidas em síntese translesão, e de potencial altamente mutagênico quando usando DNA sem lesões como molde. O sucesso evolutivo dos micro-organismos depende de um aprimoramento constante de suas taxas de mutação, para que estes aperfeiçoem a capacidade de adaptação frente às frequentes mudanças no ambiente (DENAMUR; MATIC, 2006). As mutações podem apresentar diferentes impactos no organismo, podendo ser deletérias, neutras ou benéficas (COOPER; LENSKI, 2000). As mutações contribuem significamente para o surgimento de novos caracteres em uma população e mesmo em taxas reduzidas podem resultar em significativa mudança na adaptação de microorganismo, como exemplo o surgimento de resistência a antibióticos (DENAMUR; MATIC, 2006; WOODFORD; ELLINGTON, 2007). Fenômenos de mutagênese mediados por DNA polimerases de baixa fidelidade e regulados pela resposta SOS, vêm sendo relacionados com o surgimento de resistência de antibiótico. Kohanski, Depristo e Collins (2010) demostraram que concentrações subletais de alguns antibióticos podem conduzir à multirresistência bacteriana.

Em E. coli foi demonstrado que o surgimento da resistência à ciprofloxacina durante infecção experimental requer a indução da resposta SOS e a atividade das DNA polimerases da família Y UmuD ${ }_{2} \mathrm{C}$ e DinB. Estes pesquisadores mostraram também que a inibição da resposta SOS resulta em uma diminuição na sobrevivência e mutagênese de células tratadas com ciprofloxacina (CIRZ et al., 2005; CIRZ; ROMESBERG, 2006). De forma semelhante, a DNA polimerase codificada por dnaE2 foi implicada no desenvolvimento de resistência à antibióticos em modelos murinos de infecção por Mycobacterium tuberculosis (BOSHOFF; REED; BARRY, 2003). Além disto, foi demonstrado que diversos beta-lactâmicos são capazes de induzir a transcrição do gene $\operatorname{din} B$ em $E$. coli, e com isto elevar a mutagênese, 
independente do regulon SOS (PEREZ-CAPILLA et al., 2005). Considerando o importante papel do sistema SOS na aquisição de resistência a antibióticos, estudos vêm sendo direcionados buscando-se o desenvolvimento de inibidores seletivos deste regulon, que combinados com os antibióticos, poderiam atuar reduzindo o surgimento de resistência a estas drogas (DO THI et al., 2011).

\subsection{Antibióticos beta-lactâmicos e o estresse oxidativo}

Os antibióticos beta-lactâmicos são agentes bactericidas que atuam inibindo a síntese de peptidioglicano da parede celular, por se ligarem de maneira covalente às proteínas PBPs que catalisam a reação de transpeptidação, podendo ocasionar morte celular (revisto por CHAMBERS, 2003).

Foi demostrado que antibióticos bactericidas das classes de beta-lactâmicos, quinolonas e aminoglicosídeos resultam em estresse oxidativo celular em bactérias gram negativas e positivas (FOTI et al., 2012). O estresse oxidativo resulta em vários efeitos no DNA, incluindo danos oxidativos em bases nucleotídicas e moléculas de fosfato-açúcar, assim como quebras simples (SSB) e duplas (DSB) na molécula do DNA. Além disto, SSBs localizadas em sítios próximos e opostos no DNA podem resultar em DSBs após eventos de replicação (revisto por SLUPPHAUG; KAVLI, B; KROKAN, 2003). Se não reparadas, DSBs podem ser letais para as células, enquanto que lesões em bases nucleotídicas podem ser mutagênicas e/ou citotóxicas (PFEIFFER; GOEDECKE; OBE, 2000). A via de reparo de recombinação homóloga mediada por RecBCD apresenta papel crucial no reparo de DSBs (KUZMINOV, 1999).

O estresse oxidativo envolve a formação concomitante de múltiplos danos, sendo que mais de 20 lesões em bases nucleotídicas foram identificadas. O dano 8-oxoG é considerado o mais prevalente entre as lesões que acometem bases purínicas, enquanto o timina glicol (Tg) é mais frequente entre as bases pirimídicas. Outra lesão muito frequente é formamidopirimidina Fapy-dG (2,6-diamino-4-hidroxi-5-formamidopirimidina), considerada o segundo principal produto da oxidação da guanina. A remoção das bases oxidadas Tg envolvem a participação de endonuclease III (Endo III) e endonuclease VIII (Endo VIII), codificada pelos genes $n t h$ and $n e i$, respectivamente, em E.coli. Por outro lado danos do tipo formamidopirimidina são removidos pela DNA glicosilase Fpg, codificada pelo gene mutM. Danos Fapy-dG e Tg são 
considerados menos mutagênicos em relação ao dano 8-oxoG (DIANOV et al., 2000; PATRO et al., 2007). Por outro lado, lesões Fapy e Tg são altamente citotóxicos para as células, por atuarem bloqueando a transcrição e replicação (BASU et al., 1989). Já as lesões 8-oxoG são consideradas extremamente mutagênicas e pouco citotóxicas (WALLACE et al., 2002).

Independente dos alvos macromoleculares dos antibióticos bactericidas nas células, estas drogas geram ROS do tipo radical hidroxila $(\mathrm{OH} \bullet)$, que é bastante deletéria e pode resultar em danos no DNA, lipídeos, proteínas e, consequentemente, resultar em morte celular (FOTI et al., 2012; KOHANSKI et al., 2007). Na presença de íons $\mathrm{Fe}^{2+}$, a reação de Fenton é a principal responsável pela formação de radicais OH• (TOUATI, 2000). Os danos gerados por este radical no DNA podem ocorrer de maneira direta ou indireta, e se não reparados, podem resultar em acúmulos de mutações (DEMPLE; HARRISON, 1994; FRIEDBERG et al., 2006). Kohanski, Depristo e Collins (2010) demostraram ainda que tratamentos com concentrações subletais de alguns antibióticos bactericidas (incluindo beta lactâmicos) resultam em multirresistência a antibacterianos, atribuída à formação de ROS que resultam em eventos de mutagênese nas células. Segundo Dwyer, Kohanski e Collins (2009) há três possibilidades para antibióticos promoverem aumento na mutagênese cromossomal: interação direta entre DNA e agente antibacteriano; indução de estresse oxidativo ou indiretamente, através da ação de DNA polimerases propensas a erros que atuam na tolerância a danos induzidos por estes agentes.

Foti e colaboradores demostraram que antibióticos bactericidas, incluindo os betalactâmicos, resultam em lesões oxidativas do tipo 8-oxoG no DNA de células bacterianas. A ocorrência destas lesões em sítios próximos pode resultar em quebras de fita dupla no DNA, pela ação das glicosilases, e isto contribui para a citotoxicidade destes antibióticos (FOTI et al., 2012). Além disto, estudos demonstraram que as lesões 8-oxoG presentes no DNA estão sujeitas a outros eventos oxidativos que podem culminar com a formação de lesões derivadas de hidantoína. Estes danos podem ser tolerados pela síntese translesão em E.coli, e são extremamente mutagênicas para as células (HENDERSON et al., 2003)

Além de beta-lactâmicos gerarem ROS, estes também induzem mutagênese dependente de enzimas polimerases da família Y em E.coli. Gutierrez e colaboradores (2012) demostraram que concentrações subinibitórias de antibióticos beta-lactâmicos induzem o regulon RpoS, resultando em uma redução na fidelidade da replicação e, consequentemente, aumento da mutagênese dependente da Polimerase IV (DinB). Além disto, Neeley e 
colaboradores (2007) demostraram em E. coli que a DNA polimerase V é fundamental para a translesão eficiente frente a lesões oxidativas de guanina, o que resulta em um aumento nos níveis de mutagênese dependente da resposta SOS.

\subsection{Objetivos}

Nosso objetivo principal neste trabalho é aprofundar os estudos sobre a resposta SOS no modelo de $C$. crescentus, desvendando seu papel no reparo de DNA e mutagênese, e avaliando o efeito de sua indução por antibióticos. Nosso trabalho foi dividido em dois objetivos principais:

- Análise funcional de alguns genes regulados pela resposta SOS em C. crescentus, investigando seu papel no reparo de DNA e mutagênese.

- Estudo dos efeitos biológicos da indução do sistema SOS por antibióticos betalactâmicos. 


\section{MATERIAL E MÉTODOS}

\subsection{Linhagens bacterianas e condições de cultivo e manutenção}

As linhagens bacterianas utilizadas neste trabalho estão listadas nas tabelas 3 e 4 .

Todos os ensaios foram realizados com construções derivadas da cepa NA1000 (EVINGER; AGABIAN, 1977). C. crescentus foi cultivada a $30^{\circ} \mathrm{C}$ em meio complexo PYE (ELY, 1991) (peptona $2 \mathrm{~g} / \mathrm{l}$, extrato de levedura $1 \mathrm{~g} / \mathrm{l} ; \mathrm{MgSO}_{4} .7 \mathrm{H}_{2} \mathrm{O}$ 0,2 g/l, $\mathrm{CaCl}_{2}$ 0,5 mM; $15 \mathrm{~g} / \mathrm{l}$ ágar para preparo de meio PYE sólido). Quando necessário, os antibióticos a seguir foram acrescidos nas seguintes concentrações: $20 \mu \mathrm{g} / \mathrm{mL}$ ácido nalidíxico, $5 \mu \mathrm{g} / \mathrm{ml}$ canamicina, $1 \mu \mathrm{g} / \mathrm{ml}$ tetraciclina, $200 \mu \mathrm{g} / \mathrm{ml}$ ampicilina, $50 \mu \mathrm{g} / \mathrm{ml}$ espectinomicina, $1 \mu \mathrm{g} / \mathrm{mL}$ gentamicina. Os estoques das cepas de C. crescentus foram mantidos a $-80^{\circ} \mathrm{C}$ com DMSO $10 \%$. As cepas mutantes para os genes recA, uvrA, mutY e dnaE2, e a cepa RSG113 portanto o cassete xylbla para estudos de mutagênese, foram obtidas previamente, e são parte do estoque de nosso laboratório.

As linhagens de E. coli DH10ß (HANAHAN, 1983) e S17-1 (SIMON; PRIEFER; PÜHLER, 1983) foram utilizadas, respectivamente, para processos de clonagem e conjugação com C. crescentus. Estas cepas foram cultivadas a $37{ }^{\circ} \mathrm{C}$ em meio LB (AUSUBEL et al., 1999) (peptona $10 \mathrm{~g} / \mathrm{l}$; extrato de levedura $5 \mathrm{~g} / \mathrm{l} ; \mathrm{NaCl} 10 \mathrm{~g} / \mathrm{l} ; 15 \mathrm{~g} / \mathrm{l}$ ágar para preparo de LB sólido). Quando necessário os antibióticos a seguir foram acrescidos nas seguintes concentrações: $100 \mu \mathrm{g} / \mathrm{ml}$ ampicilina, $50 \mu \mathrm{g} / \mathrm{ml}$ canamicina, $12,5 \mu \mathrm{g} / \mathrm{ml}$ tetraciclina e 50 $\mu \mathrm{g} / \mathrm{ml}$ espectinomicina. Os estoques destas cepas foram mantidos a $-80{ }^{\circ} \mathrm{C}$ com glicerol $20 \%$.

Tabela 3 -Linhagens de Escherichia coli utilizadas neste trabalho

\begin{tabular}{|c|c|c|c|}
\hline & Linhagens & Genótipo & Referências \\
\hline \multirow{6}{*}{$\begin{array}{c}\text { Escherichia } \\
\text { coli }\end{array}$} & DH10 $\beta$ & F-merA $\Delta($ mrr-hsdRMS-mcrBC) & HANAHAN, 1983 \\
\hline & & Ф80lacZ $\Delta \mathrm{M} 15 \Delta \mathrm{lacX} 74$ recA1 endA1 & \\
\hline & & $\operatorname{araD139} \Delta$ (araleu) 7697 galU galK rpsL & \\
\hline & & nupG & \\
\hline & S17-1 & 294::RP4-2 (Tc::Mu) (Km::Tn7) & SIMON; PRIEFER; \\
\hline & & & PÜHLER, 1983 \\
\hline
\end{tabular}


Tabela 4 - Linhagens de Caulobacter crescentus utilizadas neste trabalho

\begin{tabular}{|c|c|c|c|}
\hline Nome & Genótipo & Construção & Referência \\
\hline NA1000 & $\begin{array}{l}\text { Linhagem sincronizável utilizada como } \\
\text { padrão }\end{array}$ & --- & $\begin{array}{c}\text { EVINGER; } \\
\text { AGABIAN, } 1977\end{array}$ \\
\hline RSG162 & NA1000 $\Delta C C \_3424$ & $\begin{array}{l}\text { NA1000, plasmídeo } \\
\text { p3424del }\end{array}$ & Este trabalho \\
\hline RSG199 & NA1000 $\Delta C C \_3467$ & $\begin{array}{l}\text { NA1000, plasmídeo } \\
\text { p3467del }\end{array}$ & Este trabalho \\
\hline RSG179 & NA1000 $\Delta$ CC_2040 & $\begin{array}{l}\text { NA1000, plasmídeo } \\
\text { p2040del }\end{array}$ & $\begin{array}{l}\text { Laboratório Profa. } \\
\text { Marílis V. Marques }\end{array}$ \\
\hline $\mathrm{CC} 0627$ & NA1000 $\Delta \mathrm{CC} 0627$ & $\begin{array}{l}\text { NA1000, plasmídeo } \\
\text { p0627del }\end{array}$ & $\begin{array}{l}\text { DA ROCHA et al., } \\
2008\end{array}$ \\
\hline GM10 & NA1000 $\Delta r e c A$ & $\begin{array}{l}\text { NA1000,plasmídeo } \\
\text { precAdel }\end{array}$ & $\begin{array}{l}\text { GALHARDO et al., } \\
2005\end{array}$ \\
\hline GM40 & NA1000 $\Delta d n a E 2:: \Omega$ spec & $\begin{array}{l}\text { NA1000, plasmídeo } \\
\text { pdnaE2del }\end{array}$ & $\begin{array}{l}\text { GALHARDO et al., } \\
2005\end{array}$ \\
\hline RSG383 & NA1000 $\Delta m u t M:: \Omega$ spec & $\begin{array}{l}\text { NA1000, plasmídeo } \\
\text { pmutMdel }\end{array}$ & Este trabalho \\
\hline RSG333 & NA1000 $\Delta$ CC_3467 $\Delta d n a E 2:: \Omega$ spec & $\begin{array}{l}\text { RSG199, plasmídeo } \\
\text { pdnaE2del }\end{array}$ & Este trabalho \\
\hline RSG327 & NA1000 $\Delta$ CC_3424 $\Delta d n a E 2:: \Omega$ spec & $\begin{array}{l}\text { RSG162, plasmídeo } \\
\text { pdnaE2del }\end{array}$ & Este trabalho \\
\hline RSG330 & NA1000 $\Delta$ CC_3467 $\Delta$ CC_3424 & $\begin{array}{l}\text { RSG199, plasmídeo } \\
\text { p3424del }\end{array}$ & Este trabalho \\
\hline RSG294 & NA1000 $\Delta o x y R:: \Omega$ spec & $\begin{array}{l}\text { NA1000, plasmídeo } \\
\text { poxyRdel }\end{array}$ & $\begin{array}{l}\text { ITALIANI et } \\
\text { al.,2011 }\end{array}$ \\
\hline RSG324 & NA1000 $\Delta$ CC_3424 $\Delta r e c A$ & $\begin{array}{l}\text { RSG162, plasmídeo } \\
\text { precAdel }\end{array}$ & Este trabalho \\
\hline$u v r A$ & NA1000 $u v r A:: \operatorname{Tn} 5$ & $\begin{array}{l}\text { NA1000, transdução } \\
\text { com } \text { ФCr30 } \\
(u v r A:: \operatorname{Tn} 5)\end{array}$ & MARQUES, 2008 \\
\hline
\end{tabular}


Tabela 4 - Linhagens de Caulobacter crescentus utilizadas neste trabalho

\begin{tabular}{|c|c|c|c|}
\hline Nome & Genótipo & Construção & Referência \\
\hline RSG195 & NA1000 $\Delta$ CC_3424 uvrA::Tn5 & $\begin{array}{l}\text { RSG162, transdução } \\
\text { com } \Phi \text { Cr30 } \\
(u v r A:: \operatorname{Tn} 5)\end{array}$ & Este trabalho \\
\hline RSG221 & NA1000 $\Delta$ CC_3467 uvrA::Tn5 & $\begin{array}{l}\text { RSG199, transdução } \\
\text { com } \text { ФCr30 } \\
(u v r A:: \operatorname{Tn} 5)\end{array}$ & Este trabalho \\
\hline RSG105 & NA1000 $\Delta \operatorname{din} B:: \Omega$ spec & $\begin{array}{l}\text { NA1000, plasmídeo } \\
\text { pdinBdel }\end{array}$ & $\begin{array}{c}\text { GALHARDO et al., } \\
2005\end{array}$ \\
\hline RSG312 & NA1000 mut $Y:: \operatorname{Tn} 5$ & $\begin{array}{l}\text { NA1000, transdução } \\
\text { com } \Phi C r 30 \\
(m u t Y:: \operatorname{Tn} 5)\end{array}$ & $\begin{array}{c}\text { MARTINS- } \\
\text { PINHEIRO, } 2007\end{array}$ \\
\hline RSG113 & NA1000 $\Delta$ bla $\Delta x y l X:: b l a$ & --- & Nosso laboratório $\dagger$ \\
\hline RSG222 & NA1000 $\Delta$ bla $\Delta x y l X:: b l a \Delta C C \_3424$ & $\begin{array}{l}\text { RSG113, plasmídeo } \\
\text { p3424del }\end{array}$ & Este trabalho \\
\hline RSG224 & NA1000 $\Delta$ bla $\Delta x y l X:: b l a \Delta C C \_3467$ & $\begin{array}{c}\text { RSG113, plasmídeo } \\
\text { p3467del }\end{array}$ & Este trabalho \\
\hline RSG217 & NA1000 $\Delta$ bla $\Delta x y l X:: b l a \Delta$ CC_2040 & $\begin{array}{l}\text { RSG113, plasmídeo } \\
\text { p2040del }\end{array}$ & Este trabalho \\
\hline RSG282 & NA1000 $\Delta$ bla $\Delta x y l X:: b l a \Delta$ CC_0627 & $\begin{array}{l}\text { RSG113, plasmídeo } \\
\text { p0627del }\end{array}$ & Este trabalho \\
\hline RSG247 & NA1000 $\Delta$ bla $\Delta x y l X:: b l a \Delta d n a E 2 \Omega$ spec & $\begin{array}{l}\text { RSG113, plasmídeo } \\
\text { pdnaE2del }\end{array}$ & Nosso laboratório $\dagger$ \\
\hline RSG26 & NA1000 $\Delta$ CC_1634[pP3213] & --- & Nosso laboratório $\dagger$ \\
\hline RSG43 & 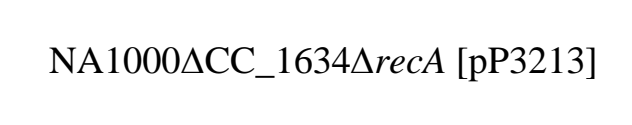 & $\begin{array}{l}\text { RSG26, plasmídeo } \\
\text { precAdel }\end{array}$ & Nosso laboratório $\dagger$ \\
\hline
\end{tabular}

$\dagger$ dados não mostrados.

\subsection{Plasmídeos}

Os plasmídeos utilizados ao longo deste trabalho nos procedimentos de clonagem e ensaios de beta-galactosidase encontram-se listados na tabela 5 . 
Tabela 5 - Plasmídeos utilizados neste trabalho

\begin{tabular}{|c|c|c|}
\hline Plasmídeo & Descrição & Fonte/Referência \\
\hline pGEM-T Easy & Vetor de clonagem, $\mathrm{Ap}^{\mathrm{r}}$ & Promega* \\
\hline pNPTS138 & Replicon ColE1, oriT, $n p t\left(K m^{r}\right), s a c B$ & D. Alley (não publicado) \\
\hline \multirow[t]{2}{*}{$\mathrm{pHP} 45 \Omega$} & Derivado do pBR322, $\mathrm{Ap}^{\mathrm{r}}$, cassete & PRENTKI; KRISCH, 1984 \\
\hline & $\Omega \operatorname{Spec}\left(\mathrm{Sm}^{\mathrm{r}}, \mathrm{Sp}^{\mathrm{r}}\right)$ & \\
\hline \multirow[t]{2}{*}{ pRKlacZ290 } & Vetor de fusão de transcrição contendo & GOBER; SHAPIRO, 1992 \\
\hline & o gene $l a c Z, \mathrm{Tc}^{\mathrm{r}}$, replicon InnP1, oriT & \\
\hline \multirow[t]{3}{*}{ precAdel } & Segmento para deleção em fase do & GALHARDO et al., 2005 \\
\hline & gene $\operatorname{rec} A$ clonado no vetor & \\
\hline & pNPTS138 & \\
\hline \multirow[t]{3}{*}{$\mathrm{pdnaE2 \textrm {del }}$} & Fragmento do gene $d n a E 2$ & GALHARDO et al., 2005 \\
\hline & interrompido pelo cassete $\Omega$ no sítio & \\
\hline & EcoRI, clonado no vetor pNPTS 138 & \\
\hline \multirow[t]{3}{*}{ pmutMdel } & Fragmento do gene CC_3707 & Este trabalho \\
\hline & interrompido pelo cassete $\Omega$ no sítio & \\
\hline & BamHI, clonado no vetor pNPTS138 & \\
\hline \multirow[t]{3}{*}{ p3424del } & Segmento para deleção em fase do & Este trabalho \\
\hline & gene CC_3424 clonado no vetor & \\
\hline & pNPTS138 & \\
\hline \multirow[t]{3}{*}{ p3467del } & Segmento para deleção em fase do & Este trabalho \\
\hline & gene CC_3467 clonado no vetor & \\
\hline & pNPTS138 & \\
\hline
\end{tabular}

* Promega, Madison, WI, EUA.

\subsection{Oligonucleotídeos}

Todos os oligonucleotídeos utilizados neste trabalho foram desenhados com auxílio do software Primer 3 e sintetizados pela empresa exxtend (São Paulo, SP, Brasil) ou Invitrogen (Carlsbad, CA, EUA). Estes se encontram listados na Tabela 6. 
Tabela 6 - Oligonucleotídeos utilizados neste trabalho

\begin{tabular}{|c|c|c|c|}
\hline Gene & $\begin{array}{l}\text { Identificação do } \\
\text { Oligonucleotídeo }\end{array}$ & Sequência $\left(5^{`} \rightarrow 3^{\prime}\right)^{a}$ & $\begin{array}{c}\text { Tamanho } \\
\text { do } \\
\text { fragmento } \\
\qquad\left(\mathbf{p b}^{*}\right)\end{array}$ \\
\hline \multirow[t]{4}{*}{ CC_3467 } & $3467 \mathrm{~A}$ & ACTAGTGACATCGTCGAGAACACCAA & 512 \\
\hline & 3467B & GGATCCAGCGCCTCAGCCTTTAG & \\
\hline & $3467 \mathrm{C}$ & GGATCCTTCGATGATCACGTCCAT & 478 \\
\hline & 3467D & GCTAGCTCCAGACGAAATGGATCAGG & \\
\hline \multirow[t]{4}{*}{ CC_3424 } & $3424 \mathrm{~A}$ & GCTAGCTATCCTCGATCATCCCGAAA & 513 \\
\hline & 3424B & GAATTCCTTGCCGTCTTCGCGCAT & \\
\hline & $3424 \mathrm{C}$ & GAATTCGCCACCGGGGTCGAATAG & 478 \\
\hline & $3424 \mathrm{D}$ & AAGCTTCCACCCTGATCTATGACGAAA & \\
\hline \multirow[t]{2}{*}{ CC_3707 } & $3707 \mathrm{~F}$ & GAATTCACGATGTTGATCGTCGC & 1015 \\
\hline & $3707 \mathrm{R}$ & GAATTCGAGTCAGCCGCTTCTTCG & \\
\hline \multirow[t]{2}{*}{ CC_1087 } & $1087 \mathrm{~A}$ & CTAAACCCAATTCCGGTTCC & 1524 \\
\hline & $1087 \mathrm{D}$ & GGTCGGTTGTTGAAGTATCCA & \\
\hline \multirow[t]{2}{*}{ CC_0627 } & 0627A & GAATTCTCGTGGTCACCGATG & 1266 \\
\hline & 0627D & CTGCAGCGCTCAGGTTGCATG & \\
\hline
\end{tabular}

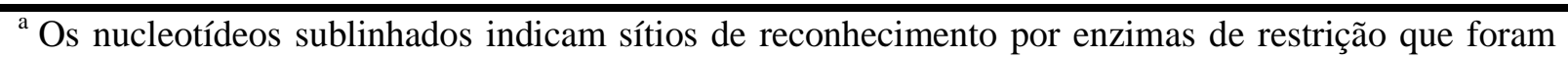
acoplados aos oligonucleotídeos

*pb: pares de bases

\subsection{Obtenção de bactérias competentes}

Para as células DH10 $\beta$ e S17-1 de E. coli tornarem-se quimiocompetentes, utilizamos a técnica descrita por Hanahan (1993). Uma colônia de E. coli obtida de uma placa recente de LB ágar foi inoculada em $2 \mathrm{ml}$ de meio LB e mantida sob agitação constante a $37{ }^{\circ} \mathrm{C}$ por aproximadamente 16 horas. Este pré-inóculo foi transferido para $50 \mathrm{ml}$ de $\mathrm{LB}$ e mantido a 37 ${ }^{\circ} \mathrm{C}$ sob agitação por cerca de 3 horas para que atingisse $\mathrm{DO} 600_{\mathrm{nm}}$ entre 0,5 e 0,6. O frasco contendo a cultura foi então transferido para um recipiente com gelo e foi acrescido $0,5 \mathrm{ml}$ de $\mathrm{MgCl}_{2} 1 \mathrm{M}$. As culturas foram transferidas para tubos de polipropileno previamente resfriados 
e mantidas em repouso por 15 minutos. As células foram então precipitadas por centrifugação durante 12 minutos, a $4{ }^{\circ} \mathrm{C}$ e $3000 \mathrm{x}$ g. O sobrenadante foi desprezado e o rendimento bacteriano foi gentilmente ressuspendido em $10 \mathrm{ml}$ de solução RF I (100 mM KCl; $50 \mathrm{mM}$ $\mathrm{MnCl}_{2} .4 \mathrm{H}_{2} \mathrm{O} ; 30 \mathrm{mM}$ de acetato de potássio; $10 \mathrm{mM} \mathrm{CaCl}_{2} .2 \mathrm{H}_{2} \mathrm{O} ; 15 \%$ glicerol; $\mathrm{pH}$ 5,8), e mantido em gelo por 15 minutos. O inóculo foi novamente centrifugado a $3000 \mathrm{x} \mathrm{g}$ por 12 minutos a $4{ }^{\circ} \mathrm{C}$, o sobrenadante descartado e as células foram ressuspendidas em $2 \mathrm{ml}$ de solução RF II (10 mM Na-MOPS; $10 \mathrm{mM} \mathrm{KCl;} 75 \mathrm{mM} \mathrm{CaCl}_{2} .2 \mathrm{H}_{2} \mathrm{O} ; 15 \%$ glicerol; pH 6,8). A suspensão bacteriana foi distribuída em alíquotas de $100 \mu \mathrm{l}$ por microtubo. Todos os procedimentos foram realizados em condição estéril e mantendo as células refrigeradas.

\subsection{Transformação de células competentes por choque térmico}

Para a realização da transformação bacteriana, primeiramente as células competentes mantidas a $-80{ }^{\circ} \mathrm{C}$ foram descongeladas em gelo por 15 minutos. As transformações de E. coli ocorreram por choque térmico de $50 \mu 1$ de cultura competente com $5 \mu 1$ do DNA de interesse. Esta mistura foi mantida por 30 minutos em gelo, e então submetida a choque térmico por 2 minutos a $42{ }^{\circ} \mathrm{C}$ e, em seguida mantidos por mais 5 minutos em gelo. Após este período, 500 $\mu \mathrm{l}$ de meio $\mathrm{LB}$ foram adicionados e os microtubos foram mantidos a $37{ }^{\circ} \mathrm{C}$ por 1 hora. Ambas as linhagens DH10 $\beta$ e S17-1 de E. coli foram utilizadas em experimentos de transformação. Porém, a linhagem DH10 $\beta$ foi utilizada para ensaios de clonagem, e a linhagem S17-1 para inserção de construções em $C$. crescentus, por conjugação. Após a recuperação das células, as bactérias foram distribuídas em placas de LB acrescidas com o antibiótico apropriado e incubadas por $37^{\circ} \mathrm{C}$ por 16 horas.

\subsection{Conjugação}

A linhagem doadora de Escherichia coli S17-1 foi utilizada para introdução de plasmídeos conjugativos nas linhagens de C. crescentus. Ambas as linhagens foram previamente semeadas em meio sólido, e estas foram misturadas na proporção de 1:1 em placa de Petri contendo meio PYE sólido, e mantido a $30{ }^{\circ} \mathrm{C}$ por aproximadamente 16 horas. Após este período, a mistura bacteriana foi transferida para placas contendo PYE sólido acrescido de ácido nalidíxico, visando eliminar as células de E. coli (sensíveis a este 
antibiótico) e promover somente o crescimento de células de $C$. crescentus que são resistentes a este antibiótico. Além disto, adicionamos também ao meio um antibiótico específico, ao qual o plasmídeo conferia resistência com a finalidade de selecionar somente as células de $C$. crescentus que receberam o plasmídeo por conjugação.

\subsection{Técnicas de biologia molecular}

\subsubsection{Extração de DNA cromossomal de C. crescentus}

Para a obtenção de DNA cromossomal de $C$. crescentus utilizamos os seguintes kits: Genomic DNA Purification Kit (Fermentas, Thermo Scientific Inc., Glen Burnie, MD, EUA) ou Bacterial Genomic DNA Miniprep Kit (Axygen Scientific, Inc., Union City, CA, EUA). Os kits foram utilizados conforme especificações dos fabricantes. Além disto, utilizamos também nos procedimentos de clonagem o kit AxyPrep DNA Gel Extraction (Axygen Scientific) para extração de DNA a partir do gel de agarose.

\subsubsection{Reações de ligação de DNA}

Para as ligações de DNA utilizamos uma proporção de 3:1 (inserto:vetor); 1U de T4 DNA ligase; tampão T4 DNA ligase $1 \mathrm{X}$, e adicionamos água milliQ para se obter um volume final de $10 \mu \mathrm{l}$. As ligações entre inserto e o vetor pGEM-T Easy (Promega, Madison, WI, EUA) foram mantidas à $4{ }^{\circ} \mathrm{C}$ por cerca de 16 horas, e as ligações entre inserto e os demais vetores ocorreram à $16^{\circ} \mathrm{C}$ também por aproximadamente 16 horas.

\subsubsection{Preparação de DNA plasmidial}

A extração de plasmídeos de interesse em pequena escala foi realizada utilizando-se o kit GeneJET Plasmid Miniprep (Fermentas, Thermo Scientific), seguindo o protocolo indicado pelo fabricante. Quando maiores concentrações de DNA foram necessárias, utilizamos o kit para preparação em maior escala AxyPrep Midi (Axygen Scientific). 


\subsubsection{Eletroforese em gel de agarose}

Os DNAs plasmidiais e cromossomais obtidos da extração, amplicons e produtos de digestão foram verificados através de géis de agarose $(0,75 \%$ a $1 \%$, dependendo do tamanho dos fragmentos) em tampão TBE 0,5X (89 mM Tris base; $89 \mathrm{mM}$ ácido bórico; $2 \mathrm{mM}$ EDTA pH 8) contendo GelRed Nucleic Acid Gel Stain (Biotium, Hayward, CA, USA). Os tamanhos dos fragmentos foram determinados com o auxílio do padrão de peso molecular Ladder GeneRuller 1 kb (Fermentas, Thermo Scientific). Para visualização dos géis foi utilizado o Image Quant 300 (GE Healthcare, Piscataway, NJ, EUA), e a quantificação dos DNAs foi realizada através do espectrofotômetro NanoDrop 1000 (Thermo Scientific, Wilmington, Delaware, EUA).

\subsubsection{Reação para sequenciamento de DNA e precipitação}

Para realizar o sequenciamento dos plasmídeos pGEM-T contendo os fragmentos de interesse clonados, os DNAs plasmidiais foram extraídos com os kits acima descritos, e utilizamos 150 ng de DNA para cada reação de sequenciamento. Em cada reação (volume final de $10 \mu \mathrm{l}$ ) acrescentamos ao DNA $2 \mu \mathrm{l}$ de tampão Save Money $5 \mathrm{X}$ (200 mM de Tris-HCl; $5 \mathrm{mM}$ de $\mathrm{MgCl}_{2}, \mathrm{pH}$ 9); 3,2 pmoles do oligonucleotídeo; $1 \mu \mathrm{l}$ do mix BigDye Terminator Cycle Sequencing Ready Reaction - versão 3.1 (Applied Biosystems, Foster City, CA, EUA) e adicionamos água MilliQ estéril até completar o volume total. As reações foram submetidas a 40 ciclos de $96{ }^{\circ} \mathrm{C}$ por 10 segundos; 20 segundos a $52{ }^{\circ} \mathrm{C}$ e 4 minutos a $60{ }^{\circ} \mathrm{C}$, em termociclador (Mastercycler Gradient, Eppendorf, Hamburg, Alemanha).

Para precipitação das reações de sequenciamento, $50 \mu \mathrm{l}$ de isopropanol $75 \%$ foram adicionados ao produto da reação e, após incubação de 10 minutos à temperatura ambiente, a mistura foi centrifugada a 12000 g por 15 minutos. O sobrenadante foi descartado através de spin invertido dos tubos, e o pellet foi ressuspendido duas vezes em $150 \mu 1$ de etanol $70 \%$ e centrifugado $12000 \mathrm{x}$ g por 7 minutos. O sobrenadante foi desprezado e o pellet permaneceu a temperatura ambiente por 16 horas para posterior sequenciamento. As amostras secas e precipitadas foram então encaminhadas ao Serviço de Sequenciamento de DNA, no Instituto de Química da Universidade de São Paulo (SSDNA IQUSP). A sequência obtida foi verificada in silico com auxilio do programa BioLign versão 3.2 para análise dos contigs e da 
qualidade do sequenciamento, e através do programa BLAST (ZHANG; MADDEN, 1997), utilizando para comparação, a sequência de DNA genômico de C. crescentus CB15 disponível no GenBank.

\subsection{Construção de cepas bacterianas mutantes}

Para a construção das cepas utilizadas ao longo deste trabalho, empregamos basicamente duas diferentes metodologias: deleção em fase do gene de interesse ou inserção de cassete de resistência a antibiótico com o uso do vetor pNPTS138, ou através de transdução mediada pelo fago $\Phi \mathrm{Cr} 30$. Além disto, a construção de alguns mutantes duplos foi derivada de cepas mutantes simples, construídas previamente através de inserção aleatória do transposon Tn5. Alguns pontos pertinentes destas construções serão também apresentados a seguir.

2.8.1 Cepas bacterianas com genes interrompidos pelo transposon $\operatorname{Tn} 5$

Neste trabalho utilizamos as cepas mutantes para os genes CC0377 (mutY) e CC2590 (uvrA), as quais foram obtidas previamente por Martins-Pinheiro (2007) e Marques (2008), respectivamente. Ambas as cepas mutantes foram selecionadas a partir de uma biblioteca de clones contendo inserção aleatória do transposon Tn5 no genoma de $C$. crescentus, construída previamente por Italiani, Zuleta e Marques (2002).

Martins-Pinheiro (2007) selecionou clones desta biblioteca que resultaram em alta frequência de mutações que conferem resistência à rifampicina, o que resultou na obtenção da cepa contendo o transposon Tn5 interrompendo o gene mutY. Este gene possui 1050 nucleotídeos, e o transposon Tn5 se inseriu após o nucleotídeo 107.

A cepa contendo o transposon Tn5 no interior do gene $u v r A$ foi obtida por Marques (2008) durante uma varredura para identificar cepas com fenótipo de sensibilidade aumentada aos agentes genotóxicos luz ultravioleta B e metilmetanosulfonato (MMS). O gene uvrA apresenta 2907 nucleotídeos, e o transposon Tn5 se inseriu após o nucleotídeo 2328. 
2.8.2 Construção de cepas bacterianas por transdução com o bacteriófago $\Phi C r 30$

Os duplos mutantes CC_3424 uvrA e CC_3467 uvrA foram obtidos por transdução mediada pelo fago $\Phi \mathrm{Cr} 30$. A cepa $u v r A$ foi inoculada em meio líquido PYE acrescido com canamicina, e mantida a $30{ }^{\circ} \mathrm{C}$ por 16 horas sob agitação. Em seguida, uma alíquota de $200 \mu 1$ foi retirada deste inóculo e transferida para um microtubo contendo $100 \mu 1$ de fago $\Phi C r 30$ $\left(10^{3}-10^{4} \mathrm{pfu} / \mathrm{ml}\right)$. Esta reação foi mantida a $30{ }^{\circ} \mathrm{C}$ por 30 minutos, e, posteriormente, transferida para $3 \mathrm{ml}$ de PYE top ágar (3\% ágar) enriquecido com $1 \mathrm{mM}$ de $\mathrm{MgSO}_{4}$ a $40{ }^{\circ} \mathrm{C}$. A mistura foi então vertida em placa de PYE, e mantida a $30{ }^{\circ} \mathrm{C}$ por cerca de 48 horas. Após este período, removemos a camada de top Agar contendo as placas de lise e lavamos a placa de petri com solução tampão $\lambda$ ( $\mathrm{NaCl} 5$ mM; MgSO4 16 mM; 5 mM Tris-HCl pH 7,5 e 0,01\% gelatina), e transferimos o resíduo da lavagem e ágar para um tubo tipo falcon $(50 \mathrm{ml})$ contendo $100 \mu \mathrm{l}$ de clorofórmio. O tubo foi vortexado por alguns minutos e centrifugado a 9000 x g por 10 minutos. Após este período, o sobrenadante foi removido, transferido para uma placa de petri estéril e submetido à irradiação $\left(216 \mathrm{~J} / \mathrm{m}^{2}\right)$ por luz ultravioleta $\mathrm{C}$ para eliminação das células bacterianas e inativação dos fagos. O lisado celular contendo as partículas transdutoras $(\Phi \mathrm{Cr} 30-u v r A)$ foi estocado a $4{ }^{\circ} \mathrm{C}$ até o momento do uso.

Para transdução, as cepas mutantes simples para os genes CC_3467 e CC_3424 foram inoculadas em PYE líquido e mantidas por aproximadamente 16 horas a $30{ }^{\circ} \mathrm{C}$. Uma alíquota de $500 \mu \mathrm{l}$ destas culturas foi transferida para tubo contendo $500 \mu \mathrm{l}$ de PYE líquido e $50 \mu 1$ de lisado $\Phi \mathrm{Cr} 30-u v r A\left(10^{7} \mathrm{pfu} / \mathrm{ml}\right)$, e os tubos foram incubados a $30^{\circ} \mathrm{C}$ por 2 horas sob agitação. Os inóculos foram então semeados em placas de PYE contendo canamicina, e mantidos a 30 ${ }^{\circ} \mathrm{C}$ por 48 horas. Após este período, verificamos a formação de inúmeras colônias isoladas nestas placas, e 3 colônias isoladas de cada construção foram semeadas separadamente em placas de PYE acrescido com canamicina, e mantidas a $30{ }^{\circ} \mathrm{C}$ por 48 horas. Então, as colônias foram novamente semeadas em placas de PYE contendo canamicina e mantidas nas mesmas condições descritas. Finalmente, uma colônia isolada de cada placa foi inoculada em PYE líquido acrescido com canamicina, incubada 16 horas a $30{ }^{\circ} \mathrm{C}$ e congelada conforme descrito na seção 2.1. Realizamos o mesmo procedimento para dois controles, um contendo inóculo bacteriano com PYE (sem lisado) e outro contendo o lisado em PYE (sem bactéria), e conforme esperado, não foi observado formação de colônias nestes controles. 
2.8.3 Construção de cepas bacterianas utilizando o vetor pNPTS138

As cepas mutantes para os genes CC_3467 e CC_3424 foram construídas pelo método de deleção em fase, utilizando-se o vetor pNPTS138. Para estas construções, amplificamos por PCR dois fragmentos flanqueadores ao gene a ser deletado, sendo que o primeiro fragmento continha a porção inicial do gene somado a algumas centenas de pares de bases à 5 deste, e o segundo fragmento continha a porção final do gene juntamente com algumas centenas de bases à extremidade 3`deste. Nas extremidades dos oligonucleotídeos inserimos sítios de enzimas de restrição específicos, visando garantir a clonagem dos insertos de interesses no vetor pNPTS138 e a junção dos dois fragmentos. Todos os fragmentos obtidos por PCR foram primeiramente clonados no vetor pGEM-T (Promega) e sequenciados, visando garantir a integridade das sequências nucleotídicas de nossas construções. Com o auxílio dos sítios de restrição introduzidos nos oligonucleotídeos, os fragmentos correspondentes às porções flanqueadoras 5 e 3 de cada gene foram digeridos do vetor de clonagem pGEM-T e subclonados no vetor suicida para Caulobacter, pNPTS138, produzindo as deleções em fase. Este vetor se integra no genoma por meio de eventos de recombinação homóloga, e confere resistência a canamicina por possuir o gene $n p t l$, e sensibilidade a sacarose por carregar o gene $s a c B$, que converte este metabólito em um produto polimérico tóxico. As construções subclonadas no vetor pNPTS138 foram inseridas através de transformação na linhagem S17-1 de E. coli, e esta foi conjugada com a cepa de $C$. crescentus.

Após a conjugação, o primeiro evento de recombinação homóloga foi selecionado através da semeadura das células em placas de PYE acrescido com canamicina $(5 \mu \mathrm{g} / \mathrm{mL})$ e ácido nalidíxico $(20 \mu \mathrm{g} / \mathrm{ml})$, as quais foram mantidas a $30{ }^{\circ} \mathrm{C}$ por 48 horas. Após este período, uma colônia isolada foi removida e semeada novamente em placa de PYE contendo canamicina e ácido nalidíxico, e mantidas durante 48 horas a $30{ }^{\circ} \mathrm{C}$. Esta segunda semeadura é importante para garantir a ausência de células de E. coli. Posteriormente, uma colônia isolada foi removida e inoculada em $1 \mathrm{ml}$ de PYE líquido, sem antibiótico, por 24 horas a 30 ${ }^{\circ} \mathrm{C}$. A perda do plasmídeo após o segundo evento de recombinação homóloga foi selecionada através do crescimento das culturas em placas de PYE contendo 3\% de sacarose. Nesta etapa, somente as células submetidas ao segundo evento de recombinação serão capazes de formar colônias na presença de sacarose. Vinte colônias foram selecionadas desta etapa, e após serem 
numeradas, estas foram semeadas em placa de PYE acrescido com canamicina e PYE contendo sacarose. Selecionamos clones que não apresentaram crescimento em canamicina, e cresceram na presença de sacarose. Estes clones recombinantes foram submetidos a PCR utilizando oligonucleotídeos específicos, e os tamanhos dos amplicons foram avaliados através de eletroforese em gel de agarose $0,8 \%$ para confirmação dos clones contendo as disrupções gênicas.

A cepa mutante para o gene mutM foi construída através da inserção de um cassete que confere resistência a espectinomicina e estreptomicina no interior da região codificante deste gene. A cepa mutante para o gene dnaE2 utilizada neste trabalho, e construída previamente por nosso laboratório (GALHARDO et al., 2005), também foi construída utilizando-se esta técnica. Nestes casos, uma cópia selvagem do gene a ser interrompido pelo cassete foi primeiramente amplificada por PCR com auxílio de oligonucleotídeos específicos

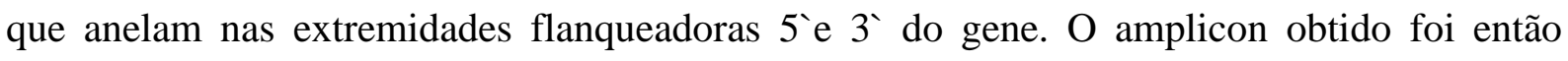
purificado e clonado no vetor pGEM-T (Promega) para sequenciamento, e procedemos uma digestão enzimática deste plasmídeo utilizando uma enzima específica que reconheça um sítio no interior do gene. O cassete de resistência a espectinomicina e estreptomicina foi obtido a

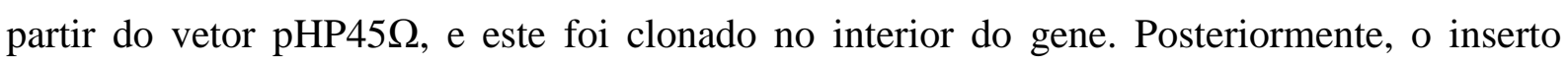
contendo o gene interrompido pelo cassete foi subclonado no vetor pNPTS138, transferida para a linhagem S17-1 de E. coli por transformação, e posteriormente transferida para linhagem de C. crescentus por conjugação. A seleção dos eventos de recombinação homóloga foi realizada conforme descrito anteriormente, porém adicionamos também a espectinomicina $(50 \mu \mathrm{g} / \mathrm{ml})$ para confirmação dos clones mutantes.

\subsubsection{Construção dos vetores plasmidiais para deleções}

Para a construção do plasmídeo contendo a deleção do gene CC_3424 (pNPTS138$\triangle$ CC_3424) dois fragmentos foram amplificados por PCR utilizando iniciadores listados na tabela 6. O primeiro fragmento (Fragmento $\mathrm{AB}$ ) continha $513 \mathrm{pb}$ e apresentava sítios reconhecidos pela enzima NheI na extremidade 5' e EcoRI na extremidade 3’, e estava localizado a montante do gene CC_3424. O segundo fragmento (Fragmento CD) apresentava $478 \mathrm{pb}$ e estava flanqueado pelos sítios das enzimas EcoRI na extremidade 5`e HindIII na porção 3', e estava situado a jusante do gene CC_3424. O mesmo procedimento foi realizado 
para construção do plasmídeo contendo a deleção do gene CC_3467 (pNPTS138- $\Delta$ CC_3467). O primeiro fragmento (Fragmento AB) estava localizado a montante do gene CC_3467, apresentava 512pb e possuía um sítio da enzima SpeI na extremidade 5`e um sítio de BamHI na extremidade 3'. Já o segundo fragmento (Fragmento CD) apresentava 478 pb e continha os sítios das enzimas BamHI na porção 5`e NheI na porção 3`, estando a jusante deste gene.

As condições de PCR para os fragmentos foram de $95{ }^{\circ} \mathrm{C}$ por 3 minutos, seguidos de 30 ciclos de $95{ }^{\circ} \mathrm{C}$ por 30 segundos, $55{ }^{\circ} \mathrm{C}$ por 30 segundos, $72{ }^{\circ} \mathrm{C}$ por 1 minuto e 10 segundos. Após os 30 ciclos as reações permaneceram a $72{ }^{\circ} \mathrm{C}$ por 10 minutos e foram mantidas a $4{ }^{\circ} \mathrm{C}$. Os produtos de PCR foram submetidos à eletroforese em gel $0,8 \% \mathrm{em}$ tampão TBE (Tris base $89 \mathrm{mM}$; ácido bórico 89 mM; EDTA $2 \mathrm{mM} \mathrm{pH} \mathrm{8).} \mathrm{As} \mathrm{bandas} \mathrm{de}$ interesse foram então recortadas do gel e purificadas com auxílio de kit (Axygen Scientific), e os DNAs foram quantificados através do espectrofotômetro NanoDrop 1000 (Thermo Scientific). Cada fragmento foi então submetido à reação de ligação com o vetor pGEM-T (Promega), conforme descrito na seção 2.7.2. Posteriormente, as ligações foram transformadas na linhagem DH10 $\beta$ de E.coli, conforme descrito na seção 2.5. Transformamos nesta linhagem um controle negativo, contendo somente o vetor submetido às mesmas condições de ligação, mas sem inserto. As culturas foram semeadas em placas de LB contendo ampicilina $(100 \mu \mathrm{g} / \mathrm{ml})$, Xgal $(40 \mu \mathrm{g} / \mathrm{ml})$ e IPTG $(100 \mathrm{mM})$, e as placas foram mantidas a $37{ }^{\circ} \mathrm{C}$ por aproximadamente 24 horas. Após este período 5 colônias brancas de cada construção foram selecionadas e inoculadas em $3 \mathrm{ml}$ de LB líquido acrescido com ampicilina. Os tubos foram mantidos sob agitação a $30{ }^{\circ} \mathrm{C}$ por cerca de 20 horas, e posteriormente procedemos a extração plasmidial com auxílio de kit (Fermentas, Thermo Scientific). Em seguida, os DNAs foram submetidos à eletroforese em gel de agarose 0,8\% para visualização das bandas. Após sequenciamento e confirmação da integridade genômica dos insertos, estes foram digeridos com as respectivas enzimas que reconhecem os sítios em suas extremidades. Os produtos obtidos da digestão foram submetidos à eletroforese, e os insertos de interesse foram recortados e purificados a partir do gel de agarose com auxílio de kit (Axygen Scientific). Os DNAs foram novamente quantificados, e posteriormente realizamos uma reação de ligação entre os dois fragmentos de cada construção (AB e CD) e vetor pNPTS138, o qual foi digerido com o par de enzimas cujos sítios estão presentes na ponta 5 do fragmento $\mathrm{AB}$ e 3 `do fragmento $\mathrm{CD}$ (Figura 9). 
As construções para deleções dos genes CC_3424 e CC_3467 resultaram em um fragmento contendo os primeiros 18 e os últimos 18 nucleotídeos destes genes.

\section{Figura 9 - Representação esquemática das construções plasmidiais para deleções nos genes CC_3424 e CC_3467 de C.crescentus}

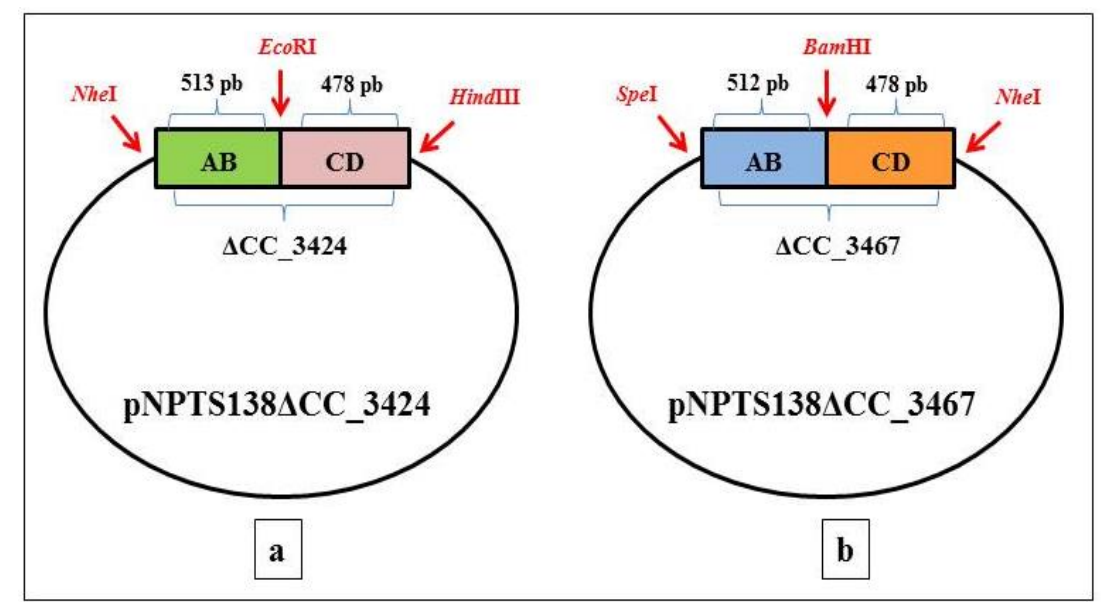

a) Fragmentos $\mathrm{AB}(513 \mathrm{pb})$ e $\mathrm{CD}(478 \mathrm{pb})$ clonados no vetor pNPTS138 para deleção do gene CC_3424. As setas vermelhas representam os sítios de digestão reconhecidos pelas enzimas NheI, EcoRI e HindIII. b) Fragmentos AB (512 bp) e CD (478 pb) clonados no vetor pNPTS138 para deleção do gene CC_3467.As setas vermelhas representam os sítios das enzimas SpeI, BamHI e NheI.

\subsection{Ensaios de sobrevivência frente a agentes genotóxicos}

Cepas mutantes de $C$. crescentus foram submetidas a tratamentos com os seguintes agentes genotóxicos: luz UVC, MMC, $\mathrm{H}_{2} \mathrm{O}_{2}$ e MMS. Para estes ensaios, culturas de $C$. crescentus foram incubadas em PYE líquido a $30{ }^{\circ} \mathrm{C}$ por cerca de 16 horas sob agitação, e diluídas em PYE para $\mathrm{DO}_{600 \mathrm{~nm}}$ equivalente a 0,1 . Os inóculos foram então mantidos nas mesmas condições por aproximadamente 3 horas até alcançarem fase exponencial de crescimento $\left(\mathrm{DO}_{600 \mathrm{~nm}}\right.$ entre 0,4 a 0,5$)$, para serem então expostas aos tratamentos.

Nos ensaios de irradiação com luz UV-C, as culturas foram irradiadas com diferentes doses de luz UVC, a partir de uma lâmpada com um pico de emissão em $254 \mathrm{~nm}$. Para os ensaios frente aos agentes $\mathrm{H}_{2} \mathrm{O}_{2}$, MMS e MMC, as células foram expostas a distintas concentrações e tempos de tratamentos. Uma alíquota não tratada era retirada previamente à exposição com os agentes para controle. Após os tratamentos, as células foram diluídas e semeadas em meio de cultura, e incubadas a $30^{\circ} \mathrm{C}$ por $48 \mathrm{~h}$ para a contagem de unidades 
formadoras de colônias (UFCs) e cálculo da fração de sobreviventes. Este cálculo foi realizado em relação ao numero de UFCs obtidas nas placas das culturas não tratadas.

\subsection{Ensaios de mutagênese frente a agentes genotóxicos}

Os ensaios para a análise da mutagênese SOS induzida por luz UV foram realizados conforme descrito anteriormente (GALHARDO et al., 2005), e como marcador utilizamos o cassete xylbla, construído previamente em nosso laboratório (dados não mostrados). Este marcador possui a vantagem de ser um marcador "forward", ou seja, que permite detectar qualquer tipo de mutação no gene alvo, neste caso o repressor $x y l R$. Basicamente, mutações em $x y l R$ são detectadas por resultarem em células resistentes à ampicilina. Realizamos também ensaios de mutagênese por luz UV utilizando marcador $r p o B$ que confere resistência à rifampicina. A porção da subunidade $\beta$ da DNA polimerase envolvida na ligação à rifampicina é altamente conservada em procariotos e mutações no gene $r p o B$ que conferem resistência a este antibiótico foram estudados em distintos micro-organismos (ZEIBELL et al., 2007). As células irradiadas com luz UV foram inoculadas em meio de cultura e mantidas a $30^{\circ} \mathrm{C}$ por um pernoite para permitir a fixação das mutações. As células foram então diluídas e semeadas em meio PYE para contagem do número de células viáveis, e também semeadas em meio PYE contendo $200 \mu \mathrm{g} / \mathrm{ml}$ de ampicilina para a contagem do número de mutantes no gene $x y l R$, e em meio PYE contendo $100 \mu \mathrm{g} / \mathrm{ml}$ de rifampicina para contagem de mutantes no gene rрoB.

\subsection{Teste flutuação para determinação da mutagênese espontânea e induzida por cefalexina}

A determinação das taxas de mutação em células crescidas na presença de concentrações subinibitórias de cefalexina foi feita utilizando-se testes de flutuação (ROSCHE; FOSTER, 2000). Estes consistem em determinar as frequências de mutantes (número total de mutantes por células viáveis) em várias culturas independentes. Nestes ensaios as culturas das cepas de interesse de C. crescentus foram inoculadas em PYE e crescidas por cerca de 16 horas a $30{ }^{\circ} \mathrm{C}$, e posteriormente diluídas em PYE para $10^{5}$ células/ml. Concentrações subinibitórias adequadas de cefalexina foram adicionadas para 
cada uma das cepas, conforme valores determinados previamente nos ensaios de CIM. Alíquotas de $1 \mathrm{ml}$ foram distribuídas em 11 tubos de ensaio e estes foram mantidos por 48 horas a $30{ }^{\circ} \mathrm{C}$ sob agitação. $\mathrm{O}$ mesmo procedimento foi realizado para o controle não tratado com cefalexina. Após este período, o número de células viáveis foi determinado por diluição seriada e plaqueamento em meio PYE. O número de mutantes presentes em cada uma das culturas foi determinado através de plaqueamento em meio PYE contendo rifampicina (100 $\mu \mathrm{g} / \mathrm{ml}$ ). Estes números foram então utilizados para calcular as taxas de mutação, utilizando-se o método da mediana de Lea-Culson (ROSCHE; FOSTER, 2000). Neste caso, o marcador a ser utilizado foi apenas o de resistência à rifampicina, tendo em vista que o cassete xylbla codifica para resistência aos beta-lactâmicos, e por esta razão não pôde ser usado nestes experimentos. $\mathrm{O}$ cálculo das taxas de mutação foi realizado utilizando o método de Maximum Likelihood, com auxílio do programa FALCOR (Fluctuation Analysis Calculator).

\subsection{Ensaios para determinação da concentração inibitória mínima de cefalexina}

A cepa parental NA1000 e as cepas mutantes para os genes recA, dnaE2, oxyR, uvrA, mutY, mutM e dinB de C. crescentus foram primeiramente recuperadas do freezer e semeadas em placas de PYE. Para as cepas $u v r A$, mutY o meio foi acrescido com canamicina; para as cepas dnaE2, oxyR e mutM acrescentamos espectinomicina e para a cepa $\operatorname{din} B$ não adicionamos antibiótico ao meio. Após 48 horas mantidas a $30{ }^{\circ} \mathrm{C}$, as células foram inoculadas em $5 \mathrm{ml}$ de PYE líquido, e os inóculos foram mantidos a $30{ }^{\circ} \mathrm{C}$ sob agitação por cerca de 16 horas. Em seguida, aferimos as $\mathrm{DO}_{600 \mathrm{~nm}}$ dos inóculos, e estes foram diluídos em PYE líquido (volume final 40ml) para $10^{5}$ células $/ \mathrm{ml}$. Alíquotas de $2 \mathrm{ml}$ foram distribuídas em 11 tubos de ensaios, e adicionamos concentrações crescentes de cefalexina $(1 \mu \mathrm{g} / \mathrm{ml}$ a 19 $\mu \mathrm{g} / \mathrm{ml}$ ) em intervalos de $1 \mu \mathrm{g} / \mathrm{ml}$. Realizamos também para cada cepa um controle negativo, no qual não adicionamos cefalexina. Os tubos foram mantidos a $30{ }^{\circ} \mathrm{C}$ sob agitação durante 72 horas, e a concentração inibitória mínima (CIM) foi determinada através de observação da menor concentração capaz de inibir o crescimento visível da bactéria. As leituras foram realizadas após 24 horas, 48 horas e 72 horas. O antibiótico cefalexina sempre foi preparado no momento do uso, e a concentração estoque foi de $4 \mathrm{mg} / \mathrm{ml}$. Estes ensaios foram feitos em duplicata técnica e triplicata biológica. 


\subsection{Ensaios de atividade de beta-galactosidase}

Segundo o método descrito por Miller (1972), o ensaio de beta-galactosidase permite a quantificação dos níveis de expressão de determinado gene através de clonagem de seu promotor à frente do gene repórter $l a c Z$. Neste trabalho, a expressão de operon $i m u A B$ dnaE2 foi medida usando a construção pP3213 (GALHARDO et al., 2005), que contém o promotor do gene imuA fusionado com o gene repórter lacZ. Esta linhagem foi então inoculada em meio PYE acrescido de tetraciclina $(1 \mu \mathrm{g} / \mathrm{ml})$ e mantida a $30{ }^{\circ} \mathrm{C}$ por aproximadamente 16 horas sob agitação. Em seguida, os inóculos foram diluídos em PYE para $10^{7}$ células $/ \mathrm{ml} \mathrm{e}$ diferentes concentrações subinibitórias de cefalexina $(5 \mu \mathrm{g} / \mathrm{ml}$ e $6 \mu \mathrm{g} / \mathrm{ml})$ foram acrescidas ao meio, e estas foram incubadas novamente a $30{ }^{\circ} \mathrm{C}$. Realizamos também um controle negativo, no qual as células não foram submetidas a tratamento com cefalexina. Alíquotas foram retiradas a cada intervalo de tempo para medição da $\mathrm{DO}_{600 \mathrm{~nm}}$ e também DO420nm. Foram transferidos $200 \mu \mathrm{l}$ de cada cultura para um microtubo contendo $800 \mu \mathrm{l}$ de tampão $\mathrm{Z}$ $\left(\mathrm{Na}_{2} \mathrm{HPO}_{4} .7 \mathrm{H} 2 \mathrm{O} 60 \mathrm{mM} ; \mathrm{NaHPO}_{4} \cdot \mathrm{H}_{2} \mathrm{O} 40 \mathrm{mM} ; \mathrm{KCl} 10 \mathrm{mM} ; \mathrm{MgSO}_{4} .7 \mathrm{H} 2 \mathrm{O} 1 \mathrm{mM} ; \beta-\right.$ mercaptoetanol $50 \mathrm{mM}$; pH 7) e $100 \mu \mathrm{l}$ de clorofórmio. Os microtubos foram agitados e mantidos a $30{ }^{\circ} \mathrm{C}$ por 5 minutos. Após este período, adicionamos $200 \mu \mathrm{l}$ de ONPG (oNitrofenil $\beta$-D-galactopiranosideo, $4 \mathrm{mg} / \mathrm{ml}$, em tampão $\mathrm{Z}$ sem $\beta$-mercaptoetanol), e incubamos novamente os tubos a $30{ }^{\circ} \mathrm{C}$ durante 5 minutos. A reação enzimática foi interrompida pela adição de $0,4 \mathrm{ml}$ de $\mathrm{Na}_{2} \mathrm{CO}_{3} 1 \mathrm{M}$, e as células foram centrifugadas a $11000 \mathrm{~g}$ por cinco minutos. A densidade óptica do sobrenadante foi medida a 420nm. Para os ensaios de $\beta$-galactosidase, separamos dois tubos contendo somente o meio PYE, sem adição de células bacterianas, os quais foram utilizados como controle para medição das densidades ópticas. Além disto, estes ensaios foram sempre realizados em duplicata técnica e triplicata biológica As unidades de atividade de $\beta$-galactosidase foram calculadas por meio da fórmula abaixo, onde $\mathrm{T}$ representa o tempo em minutos, $\mathrm{V}$ o volume da cultura em $\mathrm{ml}$ e $\mathrm{n}$ o número de replicatas técnicas:

$$
U=1000 x\left[\frac{\frac{\left(\sum_{n}^{1} A 420\right)}{n}}{V x T x A 600}\right]
$$




\subsection{Ensaios de disco-difusão}

Ensaios de disco-difusão foram realizados para determinação qualitativa da expressão do operon iтиAB dnaE2 por diversos antimicrobianos. Neste ensaio, utilizamos cepas contendo fusões transcricionais contendo os promotores dos genes imuA fusionados ao gene repóter lacZ construídas no background selvagem e deficiente em recA (GALHARDO et al., 2005), ambas deficientes para o gene CC_1634. A cepa selvagem apresenta uma atividade endógena de degradação do X-gal, o que compromete a inspeção visual das placas, já que estas apresentam um intenso background azul. Para contornar este problema, todas as construções utilizadas neste ensaio foram derivadas da cepa mutante para o gene CC_1634, cedida pela profa. Marilis do Valle Marques, ICB, USP. A deleção deste gene elimina grande parte do background azul, tornando a inspeção visual mais precisa. É importante ressaltar que a cepa mutante CC_1634 não apresenta diferença na resistência aos antibióticos testados, apresentando os mesmo tamanhos de halos de inibição que a cepa selvagem NA1000 de $C$. crescentus (dados não mostrados).

As linhagens foram inoculadas em meio PYE acrescido de tetraciclina $(1 \mu \mathrm{g} / \mathrm{ml})$ e mantidas a $30{ }^{\circ} \mathrm{C}$ por aproximadamente 16 horas sob agitação. Em seguida, os inóculos foram diluídos em PYE para uma $\mathrm{DO}_{600 \mathrm{~nm}}$ equivalente a 0,5 , e foram espalhados uniformemente sob placas de PYE com auxílio de "swab", de modo que a cobertura da superfície da placa ficasse homogênea. As placas de PYE continham X-gal $(40 \mu \mathrm{g} / \mathrm{ml})$ e tetraciclina $(1 \mu \mathrm{g} / \mathrm{ml})$. Discos impregnados com diferentes antibióticos (Laborclin ${ }^{\circledR}$, São Paulo, Brasil) foram aplicados no centro das placas com auxílio de pinça, e pressionados gentilmente sob superfície do meio. As placas foram mantidas abertas por cerca de 10 minutos para completa secagem, e em seguida incubada a $30{ }^{\circ} \mathrm{C}$ por 48 horas. Após este período, a leitura das placas foi realizada, e estas foram também fotografadas.

\subsection{Ensaios de imuno slot-blot para determinação de lesões 8-oxoguanina}

Ensaios de slot-blot foram realizados para determinar os níveis de danos do tipo 8oxoguanina (8-oxoG) em células não tratadas e tratadas com concentrações subinibitórias de cefalexina. Estes ensaios foram desenvolvidos em colaboração com o Prof. Carlos Menck. A cepa NA1000 foi inoculada em $5 \mathrm{ml}$ de PYE líquido e cultivada sob agitação por cerca de 16 
horas a $30{ }^{\circ} \mathrm{C}$. Aferimos a $\mathrm{DO}_{600 \mathrm{~nm}}$ e diluímos os inóculos em PYE para $10^{5}$ células $/ \mathrm{ml}$. Alíquotas de $2 \mathrm{ml}$ foram distribuídas em tubos de ensaio, e adicionamos $8 \mu \mathrm{g} / \mathrm{ml}$ de cefalexina em cada tubo, e foram mantidos a 48 horas a $30{ }^{\circ} \mathrm{C}$. Realizamos um controle negativo não tratado com este antibiótico, que permaneceu por aproximadamente 18 horas nas mesmas condições. Após estes períodos, a $\mathrm{DO}_{600 \mathrm{~nm}}$ de cada inóculo foi aferida, visando confirmar se estas se encontravam entre 0,4 a 0,6 (fase exponencial). Posteriormente, os DNAs foram extraídos e quantificados em triplicata com auxílio de NanoDrop (Thermo Scientific).

O volume corresponde a 400 ng de DNA foi então diluído em água milliQ estéril para um volume final de $100 \mu \mathrm{l}$. Estes foram então desnaturados $\left(100{ }^{\circ} \mathrm{C}\right.$ por 10 minutos $)$, transferidos imediatamente para o gelo e adicionamos $100 \mu \mathrm{lde} \mathrm{NH}_{4} \mathrm{OAc} 2 \mathrm{M}$. Os DNAs foram transferidos para uma membrana de nitrocelulose, a qual foi mantida previamente em solução de $\mathrm{NH}_{4} \mathrm{OAc} 1 \mathrm{M}$ por 5 minutos. Para esta transferência, a membrana de nitrocelulose foi primeiramente acoplada a um aparato de acrílico, e o conjunto foi parafusado a uma base, criando-se vácuo. As suspensões contendo DNA foram depositadas nas fendas deste aparato. Nas canaletas vazias (sem DNA) foram adicionados $200 \mu \mathrm{l}$ de $\mathrm{NH}_{4} \mathrm{OAc} 2 \mathrm{M}$. Todo o volume foi sugado da membrana com o auxílio de bomba de vácuo e a membrana foi retirada do aparato, e mantida em solução SSC $5 \mathrm{X}(\mathrm{NaCl} 750 \mathrm{mM} ; 75 \mathrm{mM}$ citrato de sódio) por 15 minutos a temperatura ambiente. A membrana foi então mantida em papel absorvente por alguns minutos para completa secagem, e incubada a $80{ }^{\circ} \mathrm{C}$ por 2 horas.

Posteriormente, a membrana foi incubada em solução de bloqueio contendo PBS 1X ( $\mathrm{NaCl} 137 \mathrm{mM} ; 2,7 \mathrm{mM} \mathrm{KCL} ; \mathrm{Na}_{2} \mathrm{HPO}_{4} .7 \mathrm{H}_{2} \mathrm{O} 4,3 \mathrm{mM} ; \mathrm{KH}_{2} \mathrm{PO}_{4} 1,4 \mathrm{mM}$ ) e 5\% de leite em pó por cerca de 16 horas a $4{ }^{\circ} \mathrm{C}$ sob agitação leve. Após este período, a membrana foi incubada com o anticorpo primário anti-8-oxoguanina (Medical e Biological Laboratories LTDA., Nagoya Japão) diluído 1:1000 em solução de bloqueio por 1 hora e 30 minutos a temperatura ambiente sob agitação leve. Em seguida, a membrana foi lavada 3 vezes durante 2 minutos em PBS $1 \mathrm{X}$ acrescido com $0,1 \%$ de Tween 20, e incubada por 1 hora a temperatura ambiente com anticorpo secundário anti-camundongo conjugado com peroxidase (GE Healthcare) diluído 1:2000 em solução de bloqueio. Após este período, a membrana foi lavada como descrito anteriormente, e exposta a reações de quimiluminescência utilizando o reagente Amersham ECL Western Blotting Detection (GE Healthcare). As bandas correspondentes aos níveis das lesões 8-oxoG foram visualizadas através do Image Quant 300. Estes ensaios foram realizados em duplicata técnica e triplicata biológica. 


\subsection{Análise estatística}

Para as análises estatísticas foi utilizado o teste de variância não-paramétrico de Kruskal-Wallis, seguido pelo teste de comparações múltiplas de Dunn. O nível de significância adotado para os testes estatísticos foi $\mathrm{p}<0.05$. Foram utilizados os testes nãoparamétricos devido à assimetria e variabilidade das variâncias. As análises foram realizadas pelo programa computacional Bioestat versão 5.3 (AYRES et al., 2007). 


\section{RESULTADOS E DISCUSSÃO}

Os resultados deste trabalho serão divididos basicamente em duas partes. A primeira compreende os dados referentes à análise funcional de alguns genes pertencentes ao regulon SOS de C. crecsentus, e a segunda inclui os dados referentes ao papel biológico do antibiótico cefalexina na indução da resposta SOS nesta bactéria.

\subsection{Análise funcional de alguns genes regulados pela resposta SOS em $C$. crescentus e seus papéis no reparo de DNA e mutagênese}

Os mutantes para os genes CC_3467, CC_3424, CC_0627 e CC_2040 foram construídos tanto no background da cepa selvagem NA1000 quanto no background mutante $u v r A$, deficiente na via de reparo NER. Além disto, o mutante para o gene CC_3424 também foi construído no background mutante para o gene dnaE2 e recA; e o mutante para o gene CC_3467 no background deficiente em dnaE2. Estes duplos mutantes foram construídos com o objetivo de realizar análises de epistasia com vias de reparo conhecidas.

As construções das cepas mutantes simples foram obtidas pelo método de deleções em fase do gene, sendo, portanto mutantes apolares. As cepas mutantes CC_0627 e CC_2040 derivadas da cepa NA1000 foram construídas previamente por Raquel Rocha (Laboratório Prof. Carlos Menck, ICB, USP) e Ricardo Mazzon (Laboratório Profa. Marílis Marques, ICB, USP), respectivamente.

Buscando avaliar o papel destes genes no reparo de diferentes lesões no DNA, realizamos ensaios de sobrevivência destes mutantes frente à luz UV, MMC, MMS e $\mathrm{H}_{2} \mathrm{O}_{2}$. Nestes ensaios, utilizamos as cepas selvagem e mutante $u v r A$, além das cepas nocautes para cada um dos genes selecionados, no background selvagem e deficiente na via NER.

\subsubsection{Ensaios de sobrevivência}

\subsubsection{Mutante CC_2040}

Análises dos fenótipos da cepa mutante no gene CC_2040 mostram que este mutante é cerca de 6 vezes mais sensível à $\mathrm{H}_{2} \mathrm{O}_{2}(3 \mathrm{mM})$ em relação à cepa selvagem (Figura 10). Além 
disto, o duplo mutante CC_2040 uvrA não apresenta diferenças de sensibilidade à $\mathrm{H}_{2} \mathrm{O}_{2}$ em relação ao mutante simples $u v r A$ (Apêndice - Figura A1 - A), indicando que este gene participa no reparo de lesões induzidas por $\mathrm{H}_{2} \mathrm{O}_{2}$ no DNA de $C$. crescentus, e que este reparo colabora com a via de NER. A Figura 11 mostra que a cepa deficiente no gene CC_2040 é ligeiramente mais sensível à MMC, sugerindo que este gene também participe no reparo de lesões induzidas por este agente. O mutante CC_2040 não apresentou fenótipos significativos de sensibilidade a MMS (Figura 12) e luz UV (Figura 13) em relação à cepa selvagem; assim como o duplo mutante CC_2040 uvrA em relação à cepa uvrA (Apêndice - Figura A2 - A e Figura A3 - A, respectivamente.).

Figura 10 - Efeito das deleções gênicas em CC_3424, CC_3467 e CC_2040 na resistência à $\mathrm{H}_{2} \mathrm{O}_{2}$ em C. crescentus.

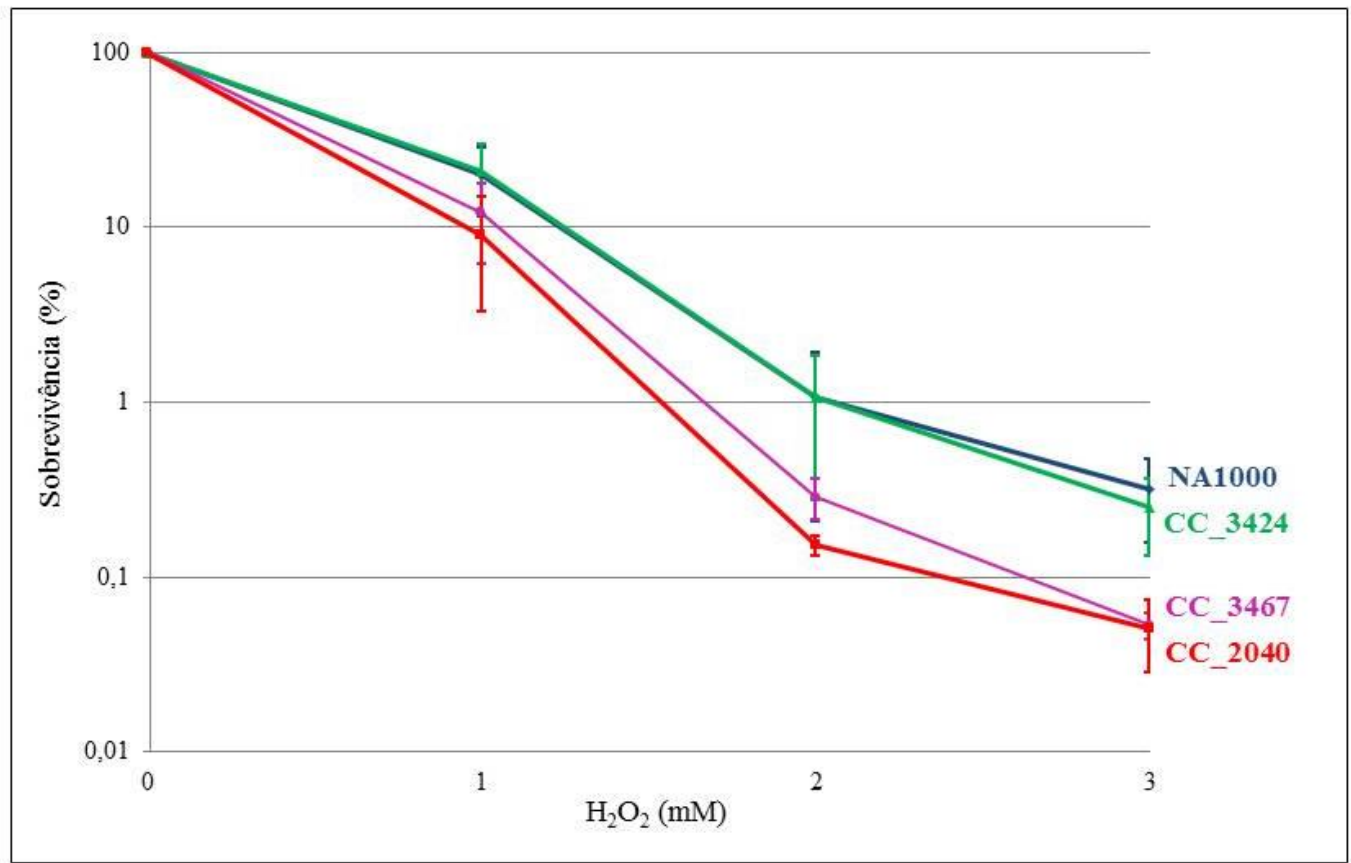

As células foram submetidas a tratamentos com concentrações de 1,2 e $3 \mathrm{mM}$ de $\mathrm{H}_{2} \mathrm{O}_{2}$ durante 60 minutos. É possível observar que a cepa mutante CC_2040 se mostrou mais sensível ao tratamento com $\mathrm{H}_{2} \mathrm{O}_{2}$ em relação à cepa selvagem NA1000. Os resultados representam a média de cinco experimentos independentes. 
Figura 11 - Efeito das deleções gênicas em CC_3424, CC_3467, CC_2040 e CC_0627 na resistência à MMC em C. crescentus.

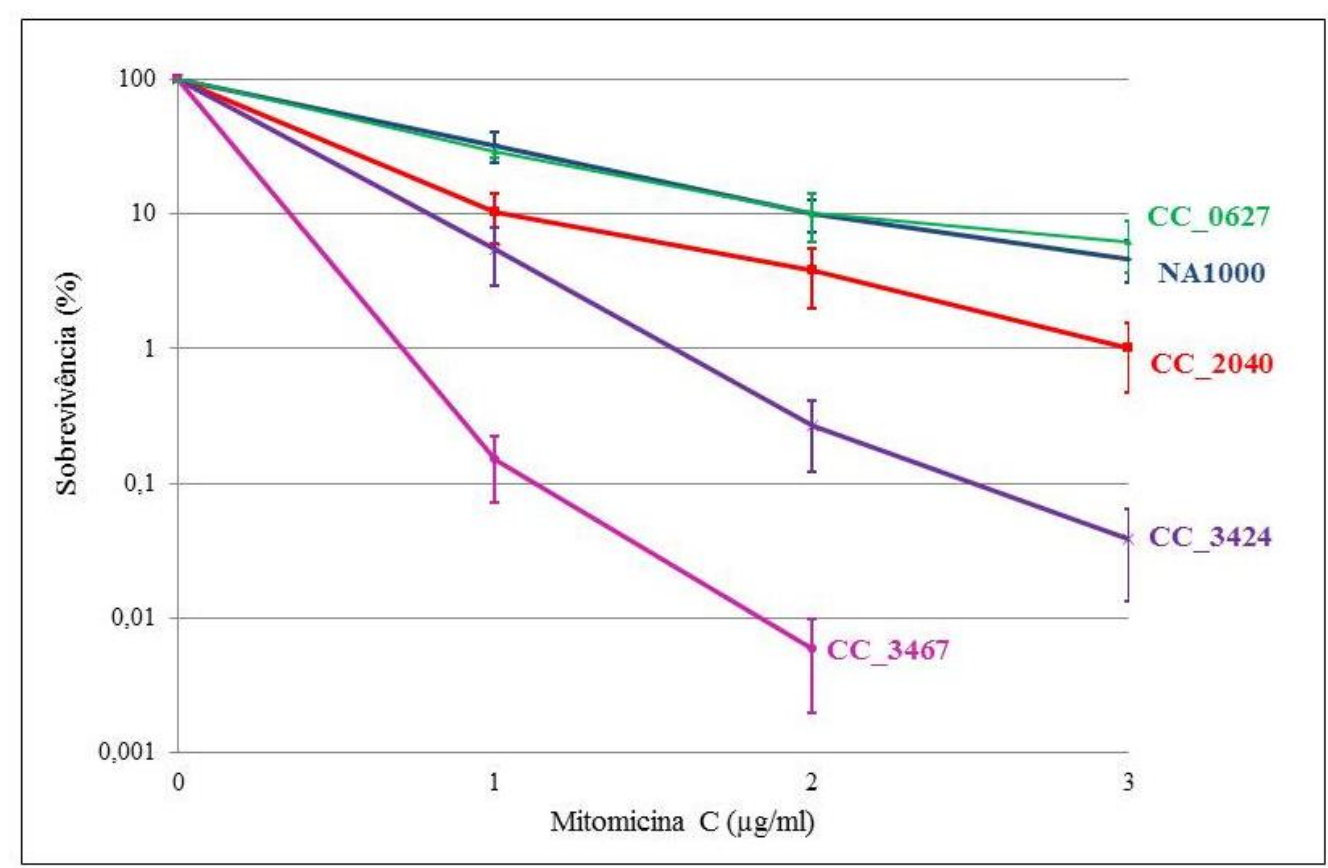

As células foram submetidas a tratamentos com concentrações de 1,2 e $3 \mu \mathrm{g} / \mathrm{ml}$ de MMC durante 60 minutos. É possível observar que as cepas mutantes CC_3424, CC_2040 e CC_3467 se mostraram mais sensíveis em relação à cepa selvagem NA1000 quando tratadas com MMC. Os resultados representam a média de três experimentos independentes.

As enzimas helicases são extremamente importantes para manutenção genômica visto que atuam promovendo a dissociação de moléculas de ácidos nucléicos. Estas enzimas auxiliam as células a lidarem com situações de estresse e danos celulares, e atuam garantindo a estabilidade cromossomal e hemostasia das células (BROSH JR, 2013). Além de atuarem na replicação e transcrição, as helicases apresentam um papel crucial em diversas vias de reparo de DNA, como via NER, BER e reparo de bases mal pareadas, além de serem essenciais para ocorrência de recombinação homóloga (KUPER; KRISKER, 2013). O gene CC_2040 provavelmente codifica uma helicase que participe nas vias de reparo de lesões induzidas por $\mathrm{H}_{2} \mathrm{O}_{2}$ e MMC, justificando o fenótipo de sensibilidade moderada a estes agentes. 
Figura 12 - Efeito das deleções gênicas em CC_3424, CC_3467, CC_2040 e CC_0627 na resistência à MMS em $C$. crescentus

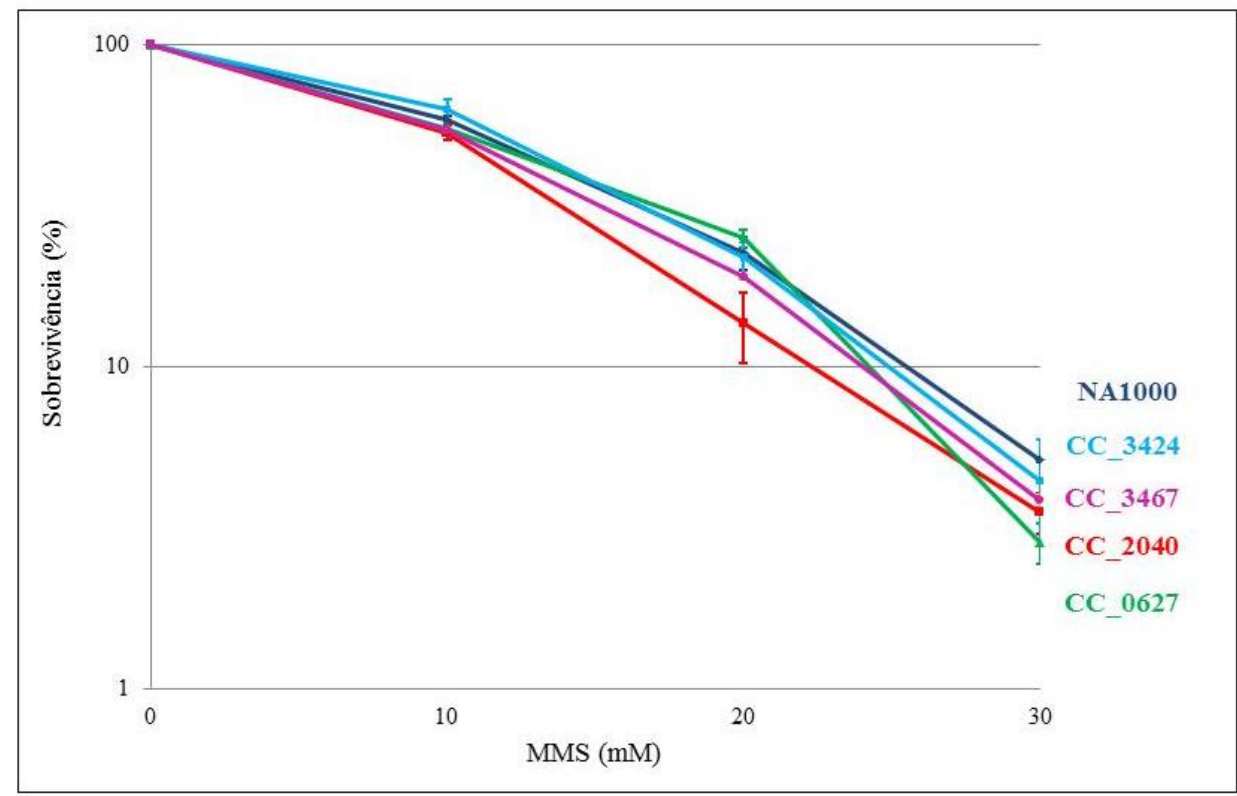

As células foram submetidas a tratamentos com concentrações de 10, 20 e $30 \mathrm{mM}$ de MMS durante 90 minutos. É possível observar que os mutantes testados não se mostraram mais sensíveis ao tratamento com MMS em relação à cepa selvagem NA1000. Os resultados representam a média de três experimentos independentes.

Figura 13 - Efeito das deleções gênicas em CC_3424, CC_3467, CC_2040 e CC_0627 na resistência à UVC em $C$. crescentus.

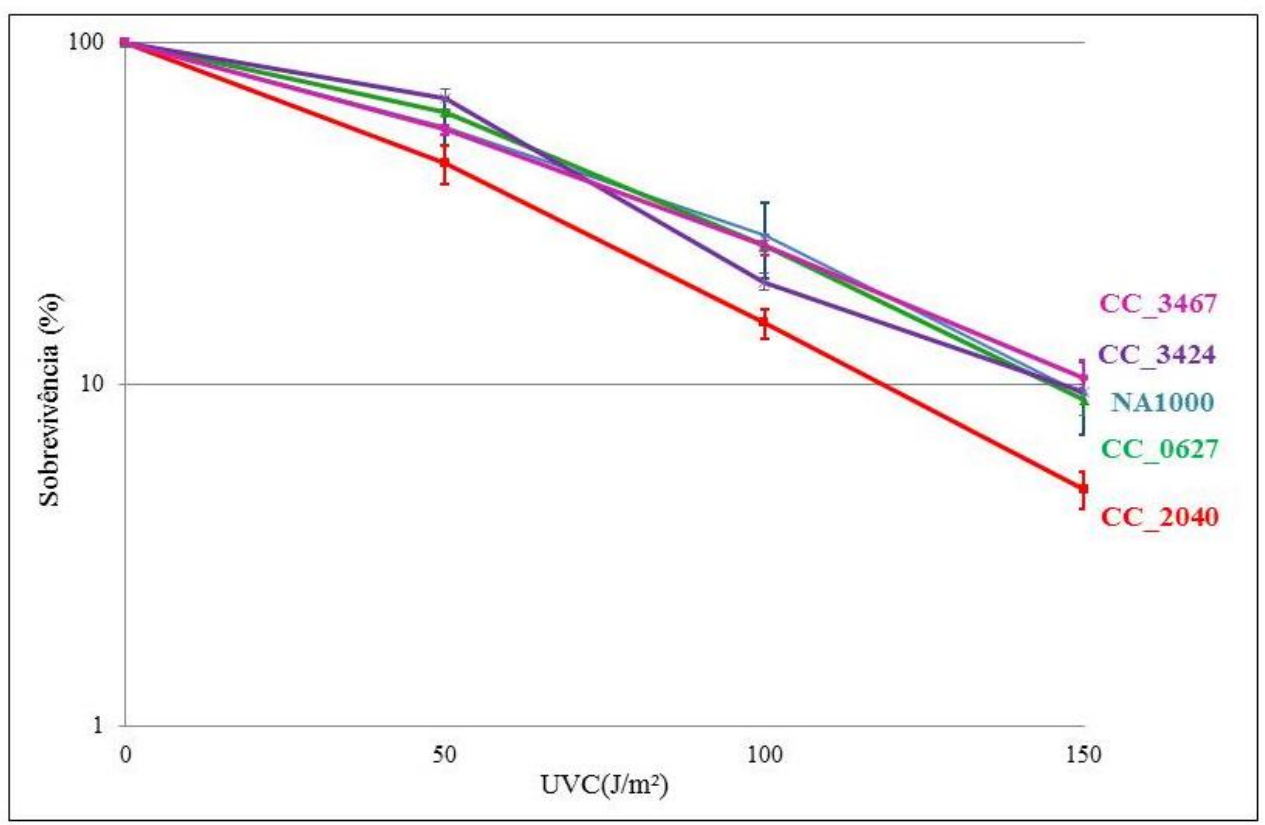

As células foram irradiadas com doses de 50,100 e $150 \mathrm{~J} / \mathrm{m}^{2}$. Os mutantes não apresentaram diferenças de sensibilidade a UVC em relação à cepa selvagem. Os resultados representam a média de três experimentos independentes. 


\subsubsection{Mutante CC_0627}

A análise dos fenótipos da cepa deficiente no gene CC_0627 mostra que este mutante não apresenta sensibilidade a MMC (Figura 11), MMS (Figura 12) e luz UV (Figura 13) assim como o duplo mutante CC_0627 uvrA não é mais sensível a MMS em relação à cepa uvrA (Apêndice - Figura A2 - D).

Tivemos um problema com esta cepa mutante, visto que os resultados obtidos em um background não se repetiam em outros backgrounds diferentes. A princípio, observamos que o mutante CC_0627 derivado da cepa NA1000 apresentou fenótipo de sensibilidade considerável à luz UVC. Porém, ao realizarmos ensaios de sobrevivência frente a este agente no mutante CC_0627 derivado da cepa RSG113 verificamos que o fenótipo de sensibilidade à luz UVC não se reproduziu. Logo, optamos por repetir todos os ensaios de sobrevivência utilizando uma nova cepa mutante CC_0627 derivada da cepa NA1000, construída também por Raquel Rocha (Laboratório Prof. Carlos Menck, ICB, USP). Os dados de análise fenotípica desta nova construção foram condizentes com os resultados obtidos no mutante derivado da cepa RSG113, confirmando que, de fato, o gene CC_0627 não apresenta papel no reparo de danos induzidos pelos agentes genotóxicos luz UV, MMS e MMC.

Bos, Yakhnina e Gitai Z (2012) caracterizaram previamente o gene CC_0627, e eles mostraram que a proteína codificada por este gene apresenta atividade de endonuclease envolvida em processos de morte celular programada em bactérias. Além disto, estes pesquisadores demonstraram que apesar do gene CC_0627 ser induzido em resposta a danos, este gene não atua no reparo de lesões no DNA. Estes dados são condizentes com os nossos resultados.

A análise funcional do gene CC_0627 foi interrompida, visto que optamos em aprofundar as análises de epistasia dos promissores genes CC_3424 e CC_3467, altamente sensíveis à MMC.

\subsubsection{Mutante CC_3467}

As análises dos fenótipos da cepa deficiente no gene CC_3467 mostram que este mutante é cerca de 180 vezes mais sensível em relação à cepa selvagem quando tratado com 1 $\mathrm{mM}$ de MMC (Figuras 11 e 14). Este agente resulta principalmente em ligações cruzadas 
intercadeia no DNA, e este reparo pode envolver várias etapas, incluindo a ação de endonucleases, via de reparo NER, via síntese translesão e também eventos de recombinação homóloga. Análises de domínios da proteína codificada pelo gene CC_3467 revelam que esta proteína apresenta similaridade com endonucleases (Apêndice - Figura A4). Conforme representado na Figura 7, o reparo de ligações cruzadas intercadeia, principal dano induzido por MMC, pode ser dependente de eventos de recombinação homóloga ou dependente de síntese translesão. Porém, ambos os mecanismos envolvem uma etapa inicial comum, mediada por endonucleases. Logo, acreditamos que o gene CC_3467 codifica uma endonuclease que atue cooperando com o reparo ou tolerância a ICLs induzidas por MMC.

Figura 14 - Efeito da deleção do gene CC_3467 na resistência à MMC em C. crescentus.

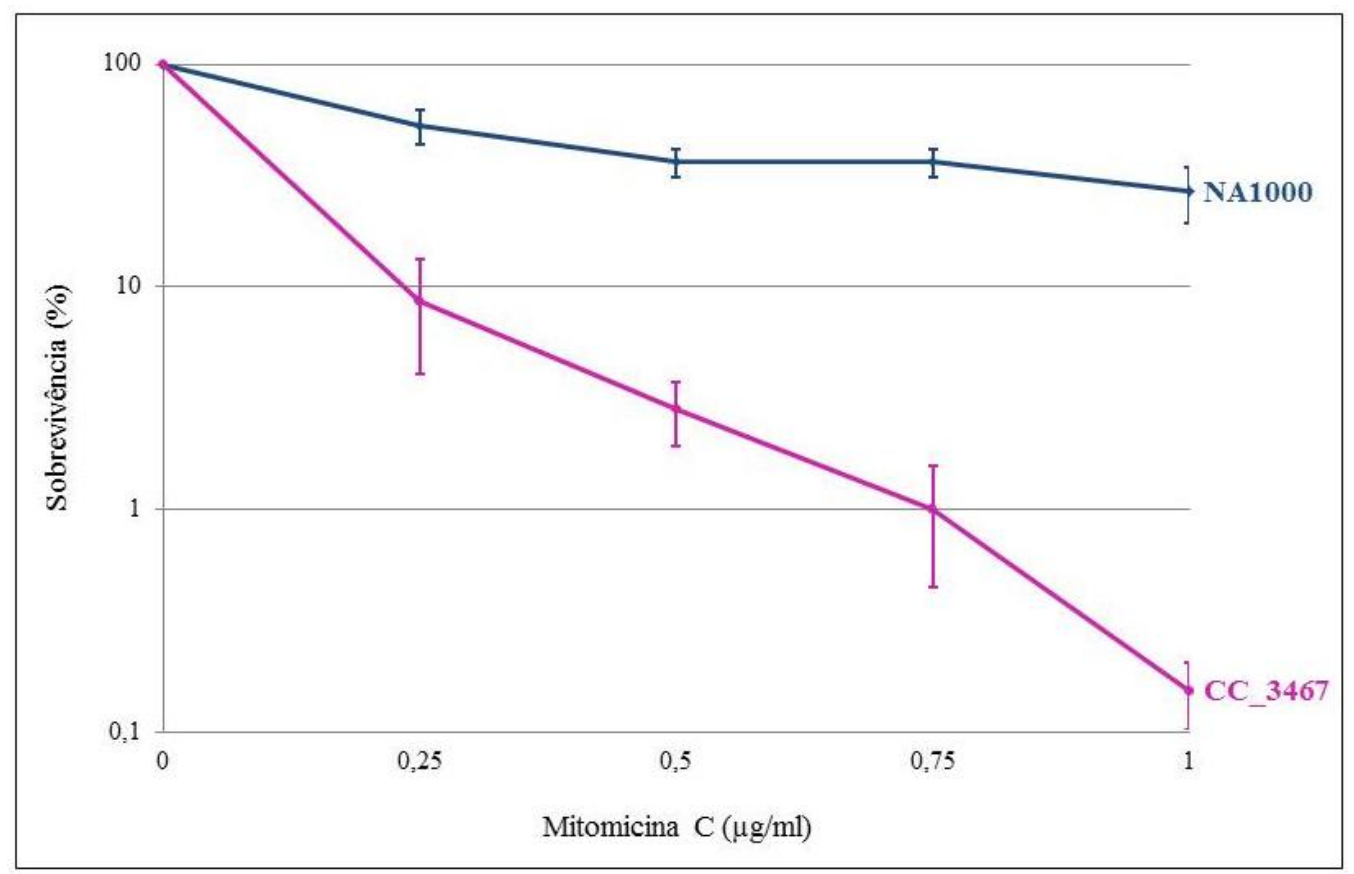

As células foram submetidas a tratamentos com concentrações de 0,$25 ; 0,5 ; 0,75$ e $1 \mu \mathrm{g} / \mathrm{ml}$ de MMC durante 60 minutos. É possível observar que a cepa mutante CC_3467 apresenta sensibilidade superior a 170 vezes em relação à cepa selvagem NA1000, quando exposta a $1 \mu \mathrm{g} / \mathrm{ml}$ de MMC. Os resultados representam a média de três experimentos independentes.

O duplo mutante CC_3467 uvrA se mostrou mais sensível à MMC em relação aos mutantes simples CC_3467 e $u v r A$ (Figura 15). Entretanto, o fenótipo apresentado pelo duplo mutante é menor do que o esperado pela soma dos fenótipos dos mutantes simples. Isto sugere que as funções da via NER e de CC_3467 sejam parcialmente sobrepostas. Possivelmente, dependendo do tipo de dano presente no DNA, a atividade endonucleolítica da proteína codificada pelo gene CC_3467 pode ser mais ou menos eficiente em relação à via NER. Logo, 
acreditamos que a proteína codificada por CC_3467 atue preferencialmente frente a determinados danos no DNA, enquanto que as endonucleases da via NER têm predileções por outros perfis de lesões. Por outro lado, estes dados sugerem que tanto a via NER como CC_3467 podem iniciar o reparo de lesões causadas por MMC na maioria dos casos, já que claramente há uma sobreposição de função entre eles.

A cepa mutante dnaE2 é sabidamente mais sensível ao agente MMC (GALHARDO et al., 2005), o que condiz com o modelo de reparo de ICLs e o papel do gene dnaE2 na síntese translesão. Além disto, nossos resultados mostram que o duplo mutante CC_3467 dnaE2 não é significativamente mais sensível à MMC em relação ao mutante simples CC_3467 (Figura 15), sugerindo que a proteína codificada por este gene atue na mesma via de reparo de danos causados por MMC que dnaE2. Um cenário plausível é que DnaE2 atue em TLS após o reparo de ICLs ser iniciado pela endonuclease codificada por CC_3467, conforme o modelo de reparo de ICLs mostrado na Figura 7. De fato, a via mediada pela Síntese Translesão no reparo de ICLs é dependente da ação de endonucleases em dois momentos: antes da ação das polimerases de translesão e posteriormente à ação destas enzimas (Figura 7), e, portanto, a proteína codificada pelo gene CC_3467 pode ser responsável por estas funções. A figura 19 esquematiza a possível via de reparo de ICLs mediado pela proteína codificada por CC_3467.

Estávamos interessados também em compreender a função da proteína codificada por CC_3467 na via de reparo de ICLs dependente de recombinação homóloga (mediada por recA). Porém, não foi possível esta análise de epistasia, visto que o mutante duplo CC_3467 recA se mostrou inviável. Durante tentativa de construção do mutante duplo, tentamos deletar o gene recA na cepa CC_3467. Selecionamos 96 clones resistentes à sacarose e sensíveis à canamicina provenientes da segunda recombinação, e todos retiveram a cópia selvagem do gene $r e c A$. Este dado sugere que a via mediada por recombinação homóloga associada com a atividade endonucleolítica da proteína codificada por CC_3467 representam um papel essencial no reparo de lesões endógenas em C. crecsentus, de forma que o mutante duplo apresenta um fenótipo sintético letal.

A cepa mutante CC_3467 não se mostrou significantemente mais sensível em relação à cepa selvagem aos agentes genotóxicos $\mathrm{H}_{2} \mathrm{O}_{2}$ (Figura 10), MMS (Figura 12) e luz UV (Figura 13) comparando-se com a cepa selvagem; assim como o duplo mutante CC_3467 $u v r A$ em relação à cepa $u v r A$ (Apêndice - Figuras A1 - C, A2 - C, A3 - C, respectivamente). 
Estes dados indicam que a proteína codificada por CC_3467 não atue no reparo de lesões induzidas por estes agentes.

Figura 15 - Efeito das deleções gênicas em dnaE2, uvrA e CC_3467 na resistência à MMC em C. crescentus.

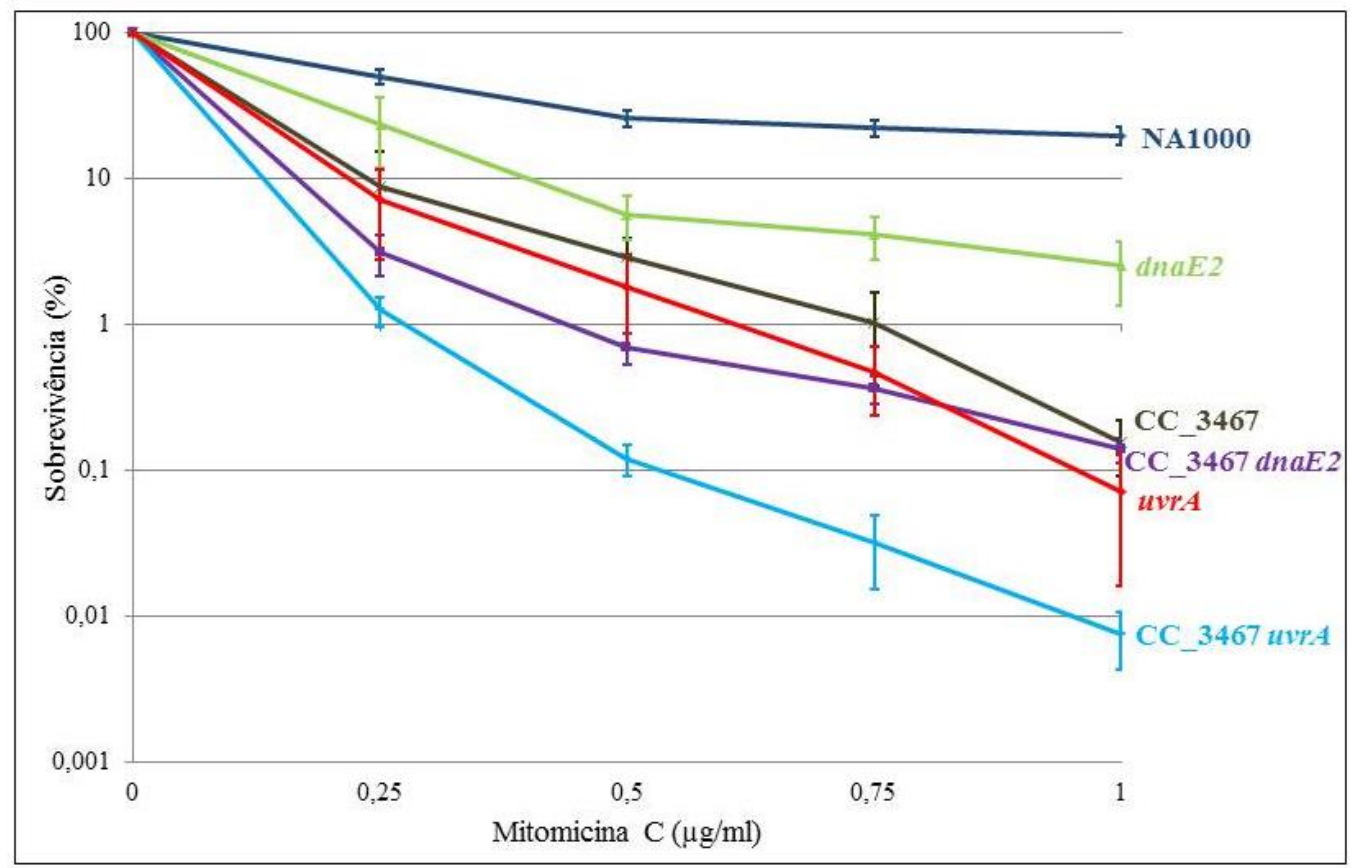

As células foram submetidas a tratamentos com concentrações de 0,$25 ; 0,5 ; 0,75$ e $1 \mu \mathrm{g} / \mathrm{ml}$ de MMC durante 60 minutos. $\mathrm{O}$ duplo mutante $\mathrm{CC} \_3467$ dnaE2 não apresentarou diferença significativa de sensibilidade à MMC em relação aos mutantes simples CC_3467. O duplo mutante CC_3467 uvrA se mostrou ligeiramente mais sensívelà este agente em relação ao mutante $u v r A$ Os resultados representam a média de três experimentos independentes.

\subsubsection{Mutante CC_3424}

Dados de ensaios de sobrevivência realizados com a cepa deficiente no gene CC_3424 mostram que este mutante é cerca de 100 vezes mais sensível em relação à cepa selvagem quando tratado com concentrações de $3 \mathrm{mM}$ de MMC (Figura 11). Análises de domínios da proteína codificada por CC_3424 mostram domínios com similaridade a glioxalases, envolvidas com resistência a antibióticos (Apêndice - Figura A5), especialmente bleomicina. Com isto, acreditamos que o gene CC_3424 possa codificar uma proteína que atue detoxificando a MMC das células, e não no reparo de danos induzidos por este agente.

Glioxalases são importantes enzimas responsáveis pela detoxificação de metilglioxal (aldeído pirúvico) e também de outros compostos $\alpha$-oxoaldeídos que são originados a partir 
do metabolismo celular (RANGANATHAN; WALSH; TEW, 1995). Estes compostos se acumulados no interior das células podem desencadear reações de glicação em importantes biomoléculas celulares, e podem resultar em mutações e mudanças na estrutura de proteínas, e até mesmo morte celular (THORNALLEY, 1998).

A glioxalase I, dioxigenase, proteínas envolvidas com resitência aos antibióticos fosfomicina (FosA), bleomicina e mitomicina C apresentam domínio protéico $\beta \alpha \beta \beta \beta$, sugerindo parentesco evolutivo (BERGDOLL et al., 1998; FEIERBERG; CAMERON; ÅQVIST, 1999). Estudos realizados com a FosA demonstraram que esta proteína, assim como a glioxalase I e dioxigenase, pertencem a mesma família de metaloenzima. A proteína FosA, por exemplo, cataliza a adição de glutationa (GSH) na molécula de fosfomicina, em presença de $\mathrm{Mn}^{2}+$, resultando na inativação deste antibiótico (BERNAT; LAUGHLIN; ARMSTRONG, 1996). Acreditamos que a proteína codificada pelo gene CC_3424 possa, de forma semelhante, atuar promovendo a inativação de mitomicina $\mathrm{C}$ em C. crescentus.

O mutante duplo CC_3424 uvrA se mostrou significantemente mais sensível à MMC em relação aos mutantes simples para estes genes (Figura 16), indicando que a proteína codificada por CC_3424 atue de maneira independente à via NER de reparo. Além disto, o mutante duplo CC_3424 recA também se mostrou mais sensível à MMC em relação aos mutantes simples para ambos os genes (Figura 16), sugerindo que a proteína CC_3424 não atue na via de reparo de ICLs mediada por recombinação homóloga. A cepa duplo mutante CC_3424 dnaE2 também apresentou fenótipo de sensibilidade mais acentuado à MMC em relação aos mutantes simples para estes genes (Figura 17), indicando que a função da proteína codificada por CC_3424 não é dependente à via TLS. Visando verificar se os genes CC_3424 e CC_3467 atuam de maneira cooperativa na via de tolerância à MMC, realizamos ensaios de sobrevivência frente a este agente com a cepa mutante dupla CC_3424 CC_3467. Os dados mostram que este mutante duplo é mais sensível à MMC em relação os mutantes simples para cada um destes genes (Figura 18), indicando que eles atuam em vias distintas para promover tolerância a este agente. Todos estes dados analisados em conjunto favorecem nossa hipótese de que o gene CC_3424 codifique uma proteína que atue na detoxificação da MMC e não no reparo em si das lesões induzidas por este agente. 
Figura 16 - Efeito das deleções gênicas em CC_3424, dnaE2, recA e uvrA na resistência à MMC em C. crescentus.

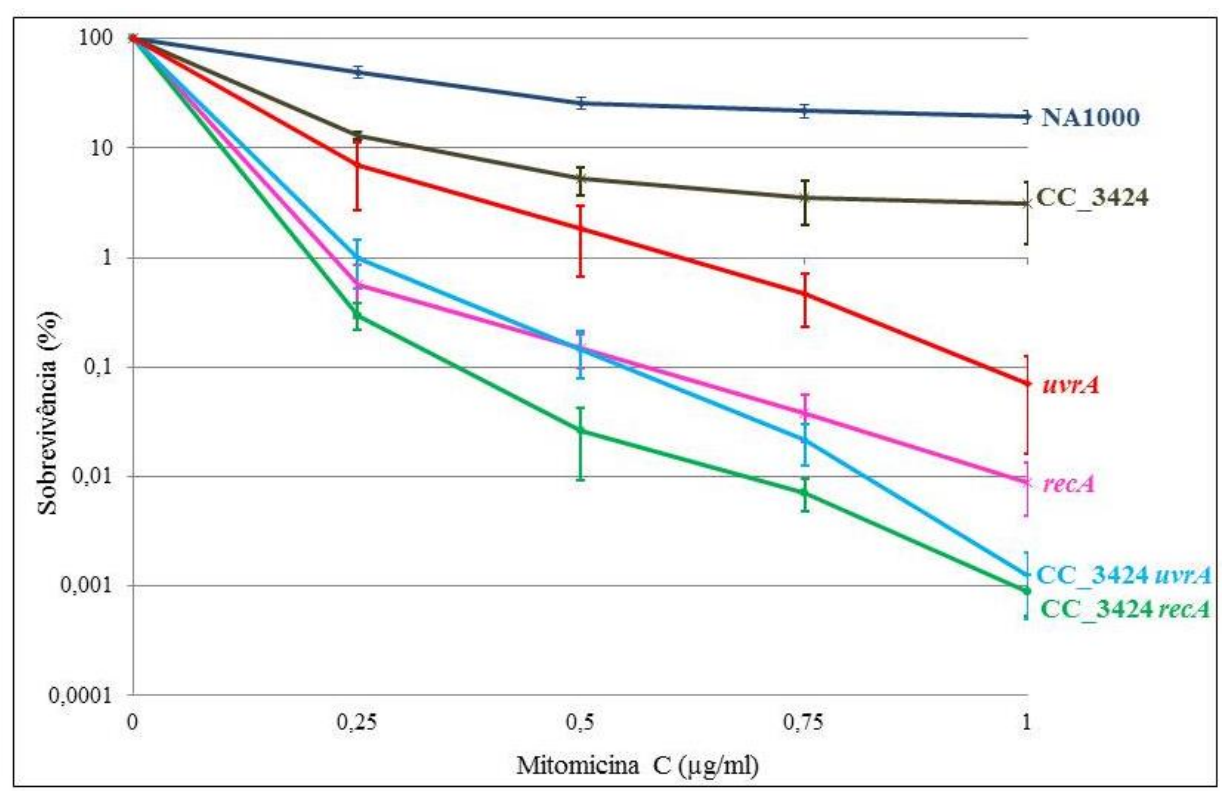

As células foram submetidas a tratamentos com concentrações de 0,$25 ; 0,5 ; 0,75$ e $1 \mu \mathrm{g} / \mathrm{ml}$ de MMC durante 60 minutos. Os mutantes duplos se mostraram mais sensíveis a MMC em relação aos seus respectivos mutantes simples. Os resultados representam a média de cinco experimentos independentes.

\section{Figura 17 - Efeito das deleções em $\mathrm{CC}_{-} 3424$ e dnaE2 na resistência à $\mathrm{MMC}$ em $C$.} crescentus.

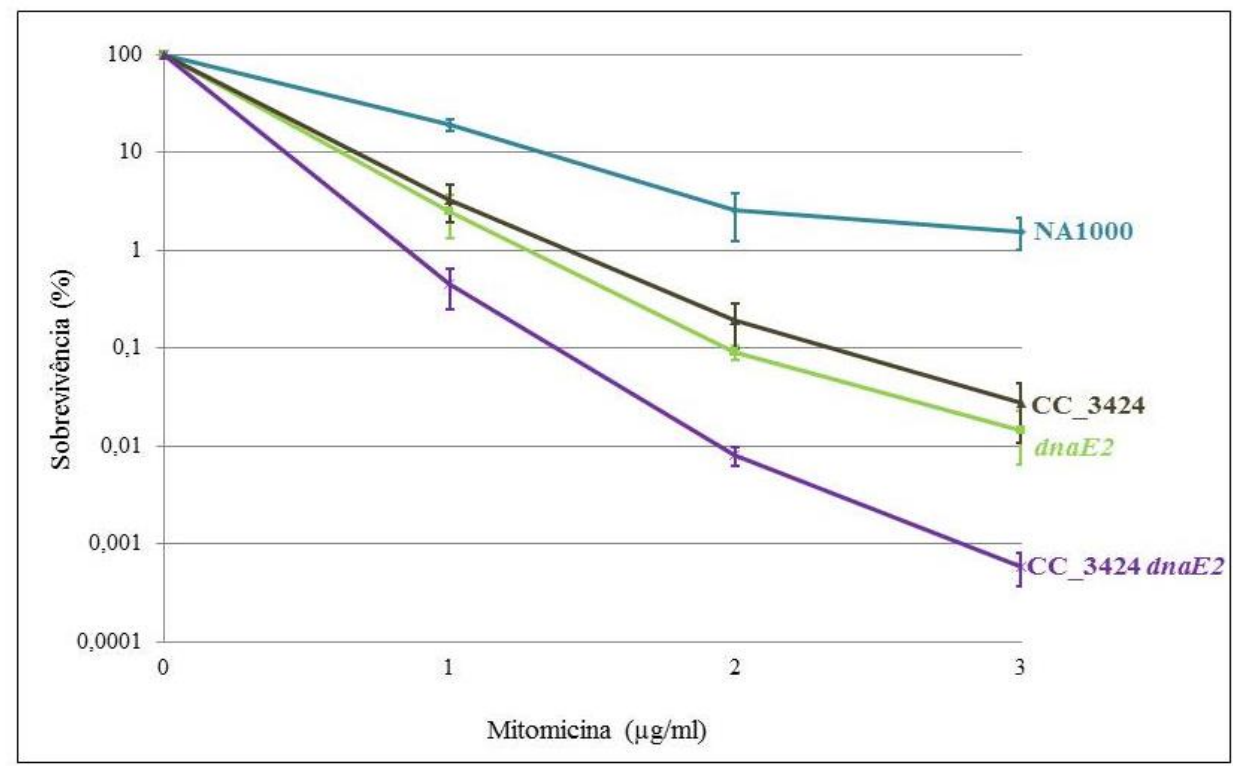

As células foram submetidas a tratamentos com concentrações de 1,2 e $3 \mu \mathrm{g} / \mathrm{ml}$ de MMC durante 60 minutos. O mutante duplo CC_3424 dnaE2 apresentou maior sensibilidade à MMC em relação aos mutantes simples de cada gene. Os resultados representam a média de cinco experimentos independentes. 
Figura 18 - Efeito das deleções gênicas em CC_3424 e CC_3467 na resistência à MMC em $C$. crescentus.

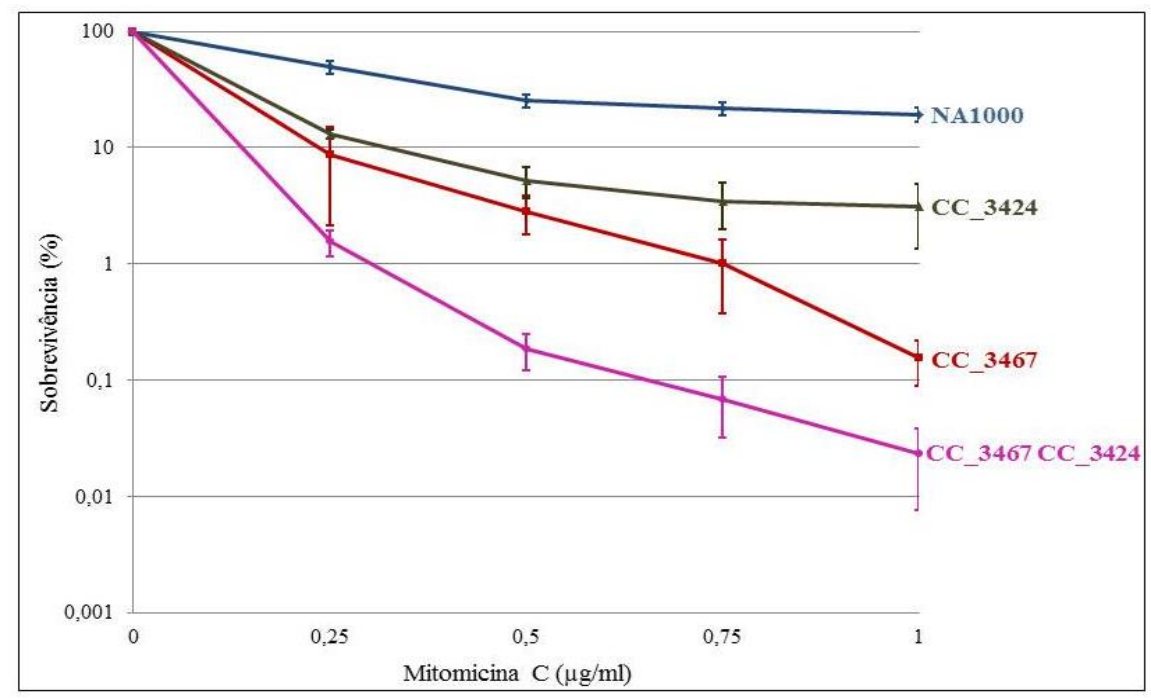

As células foram submetidas a tratamentos com concentrações de 0,$25 ; 0,5 ; 0,75$ e $1 \mu \mathrm{g} / \mathrm{ml}$ de MMC durante 60 minutos. É possível observar que o duplo mutante CC_3467 CC_3424 é mais sensível à MMC em relação aos mutantes simples de cada gene. Os resultados representam a média de cinco experimentos independentes.

Por outro lado, a cepa mutante para o gene CC_3424 não apresentou fenótipo de sensibilidade para os agentes genotóxicos $\mathrm{H}_{2} \mathrm{O}_{2}$ (Figura 10), MMS (Figura 12) e luz UV (Figura 13), assim como o duplo mutante CC_3424 uvrA em relação à cepa uvrA (Apêndice Figuras A1 - B, A2 - B, A3 - B, respectivamente). Estes dados indicam que a proteína codificada por este gene não apresenta papel no reparo ou tolerância aos danos induzidos por estes agentes.

\subsubsection{Genes $C C \_3467$ e CC_3424 e a tolerância à mitomicina $C$}

As análises fenotípicas nas cepas deficientes para os genes CC_3467 e CC_3424 mostraram que estes mutantes são consideravelmente mais sensíveis à MMC e, portanto, apresentam papel na tolerância a este agente em C. crescentus. Porém, os dados obtidos nestas análises mostram que estes genes possivelmente atuam em vias distintas para promover tolerância à MMC. O gene CC_3467 codifica uma proteína que apresenta domínios com similaridade a endonucleases (Apêndice - Figura A4). Como as vias propostas para o reparo de ligações cruzadas intercadeia é dependente da participação de endonucleases, acreditamos 
que este gene atue no reparo destes danos. O papel de CC_3467 no reparo de ICLs proposto por nós para explicar os nossos resultados está descrito no modelo mostrado na Figura 19.

\section{Figura 19 - Representação esquemática do reparo de ligações cruzadas intercadeia induzidas por mitomicina $\mathrm{C}$ em Caulobacter crescentus}

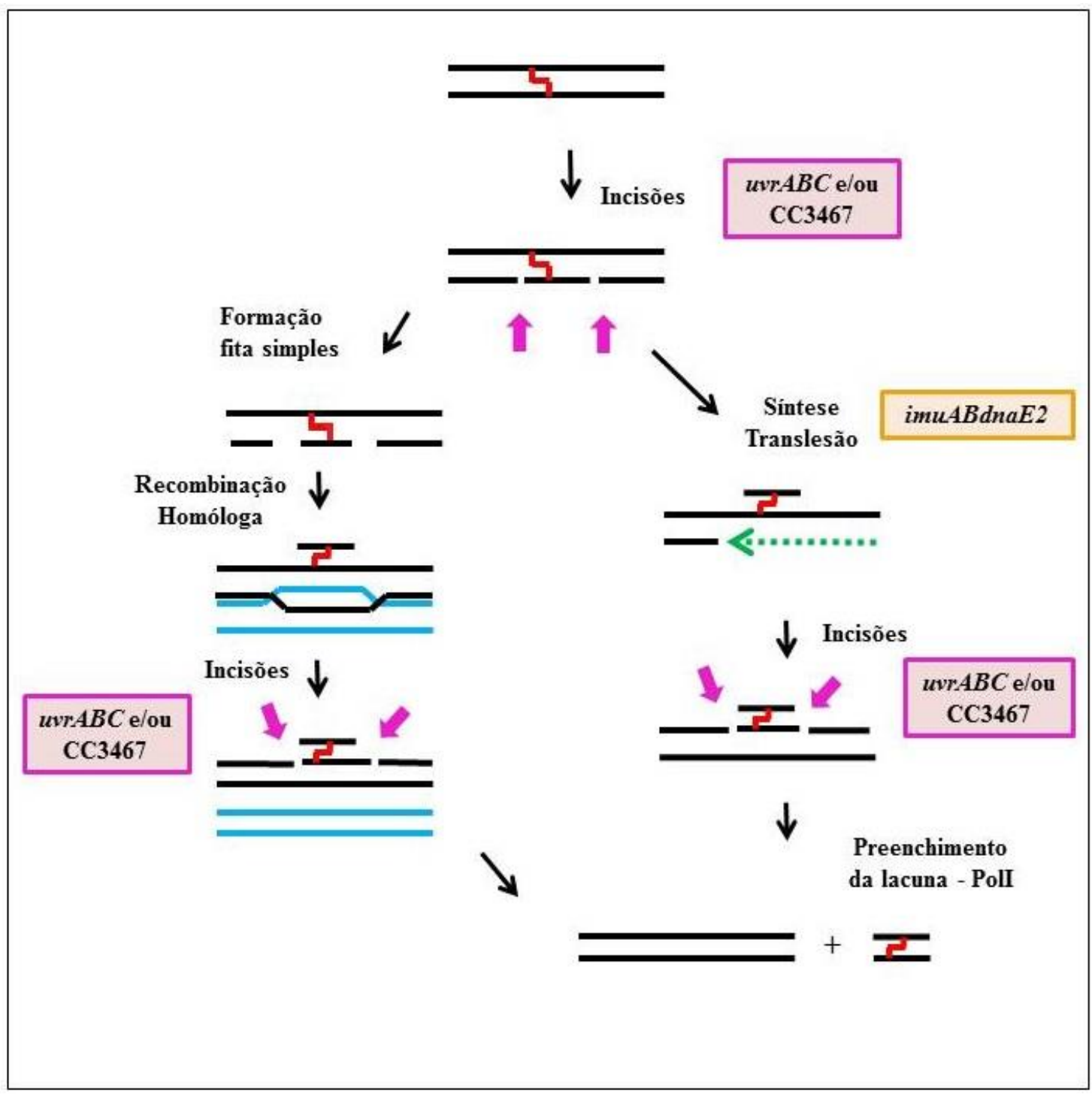

A via de reparo de ligações cruzadas intercadeia pode ser dependente de recombinação homóloga ou Síntese Translesão. Ambos os mecanismos envolvem a participação de endonucleases. Os resultados obtidos neste trabalho sugerem que o reparo de ICLs por MMC pode ser iniciado por CC_3467 ou pelas proteínas mediadas pela via NER. As setas rosas mostram as possíveis etapas que esta proteína exerça sua atividade.

A proteína codificada pelo gene CC_3424 apresenta domínios de similaridade com glioxalases e dioxigenases relacionadas com resistência a antibióticos e compostos relacionados à mitomicina $\mathrm{C}$ (Apêndice - Figura A5). Por isto, acreditamos que este gene 
esteja envolvido com um processo de detoxificação de MMC, e que não apresente papel no reparo de lesões induzidas por este agente. Para se melhor compreender o papel destes genes no reparo de lesões induzidas por MMC, uma abordagem futura interessante seria medir o reparo deste dano em cepas deficientes para estes genes através de ensaios de PCR de longo alcance (FURDA et al., 2012). Se estes genes realmente atuam em vias distintas na tolerância à MMC, esperamos não observar alterações na evolução do reparo de lesões por MMC na cepa deficiente no gene CC_3424 e que o este reparo ocorra de maneira mais lenta na cepa mutante CC_3467. Desta forma, poderemos distinguir as atividades destes dois produtos gênicos, e testar a hipótese que CC_3424 se trata de uma proteína de detoxificação, e CC_3467 se trata de um gene de reparo de DNA propriamente dito.

\subsubsection{Mutagênese induzida por luz UVC}

Após os ensaios de sobrevivência frente aos diferentes agentes genotóxicos, o próximo passo foi realizar ensaios de mutagênese utilizando marcadores de resistência a rifampicina e ampicilina, visando determinar as taxas de mutações induzida por luz UV em cada uma das cepas nocaute. Estudos realizados por nosso laboratório (GALHARDO et al., 2005) demonstraram que a mutagênese induzida por luz UV não é completamente dependente da via TLS, e, portanto, a atividade de outras proteínas colaboram para a mutagênese induzida por luz UV. Portanto, os experimentos de mutagênese induzida por luz UV visavam avaliar se os genes sob investigação neste estudo poderiam contribuir para a via de síntese translesão, responsável por introduzir mutações no DNA após a exposição de $C$. crescentus à luz UV.

Para estes ensaios, utilizamos as cepas RSG113 (cepa contendo o cassete xylbla) e os mutantes derivados desta cepa CC_0627, CC_2040, CC_3467, CC_3424 e dnaE2. As Figuras 20 e 21 mostram que as cepas deficientes nos genes CC_2040, CC_3467, CC_0627 e CC_3424 não apresentam diferenças significativas na mutagênese induzida por luz UV em relação à cepa RSG113, em ensaios de mutagênese utilizando marcadores de resistência a rifampicina e ampicilina, respectivamente. Estes dados indicam que estes genes não participam do processo de síntese translesão em resposta a fotoprodutos induzidos por luz UV. Por outro lado, a cepa mutante dnaE2 exibiu uma redução de cerca de duas vezes destas mutações induzidas por luz UV (em ambos os marcadores de resistência), indicando que a mutagênese induzida por UV é um processo parcialmente dependente do operon 
imuABdnaE2. Estes dados confirmam os resultados publicados por nosso grupo previamente (GALHARDO et al., 2005).

Figura 20 - Efeito das deleções gênicas em dnaE2, CC_3424, CC_3467, CC_2040 e CC_0627 na mutagênese induzida por luz UVC em $C$. crescentus utilizando o marcador de resistência a rifampicina

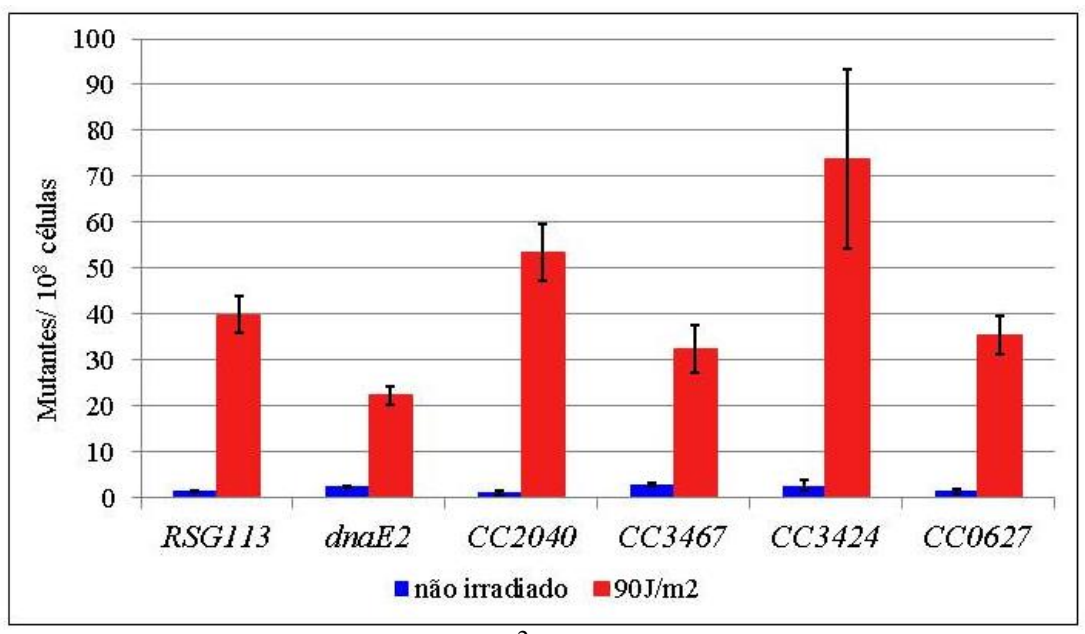

As células foram irradiadas com dose de $90 \mathrm{~J} / \mathrm{m}^{2}$ de luz UVC para ensaio de mutagênese. Os dados mostram que as cepas mutantes testadas não apresentaram aumento de mutagênese provocado pela irradiação com luz UV em relação à cepa selvagem de $C$. crescentus em ensaios utilizando marcador de resistência à rifampicina. Os resultados representam a média de cinco experimentos independentes.

Figura 21 - Efeito das deleções gênicas em dnaE2, CC_3424, CC_3467, CC_2040 e CC_0627 na mutagênese induzida por luz UVC em $C$. crescentus utilizando o marcador de resistência a ampicilina

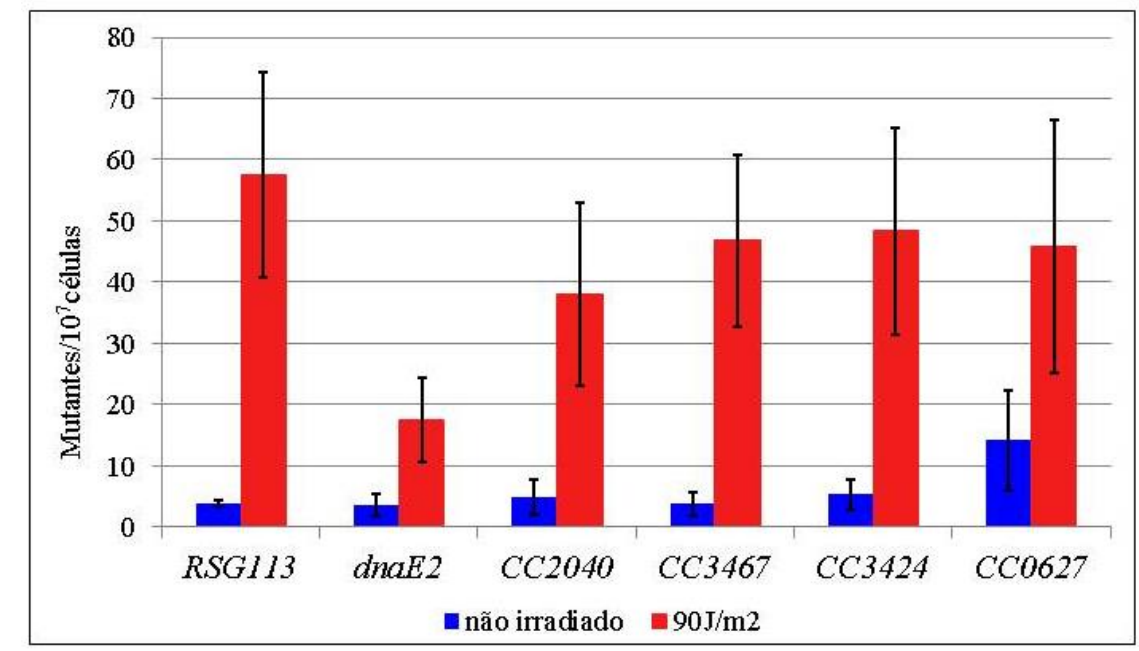

As células foram irradiadas com dose de $90 \mathrm{~J} / \mathrm{m}^{2}$ de luz UVC para ensaio de mutagênese. Os dados mostram que as cepas mutantes testadas não apresentaram aumento de mutagênese provocado pela irradiação com luz UV em relação à cepa selvagem de $C$. crescentus em ensaios utilizando marcador de resistência à ampicilina. Os resultados representam a média de cinco experimentos independentes. 


\subsection{Estudo dos efeitos biológicos da indução do sistema SOS por antibióticos beta- lactâmicos}

\subsubsection{Ensaio de disco-difusão}

Visando determinar qualitativamente a indução da resposta SOS mediada por antibióticos, realizamos ensaios de disco-difusão frente a diferentes antimicrobianos. Para este ensaio, empregamos construções contendo uma fusão transcricional do promotor do gene imuA com o gene repóter lacZ, derivadas da cepa selvagem e cepa deficiente em recA.

Através de ensaios de disco-difusão demonstramos que alguns antibióticos são capazes de induzir a resposta SOS em concentrações subinibitórias (Figuras 22, 23 e 24). Dentre os antibióticos testados, vários beta-lactâmicos parecem de fato induzir a expressão da resposta SOS em C. crescentus, em especial a cefalexina (Figura 22).

\section{Figura 22 - Testes de disco-difusão e a indução da atividade de PimuA frente a cefalexina e ciprofloxacina}

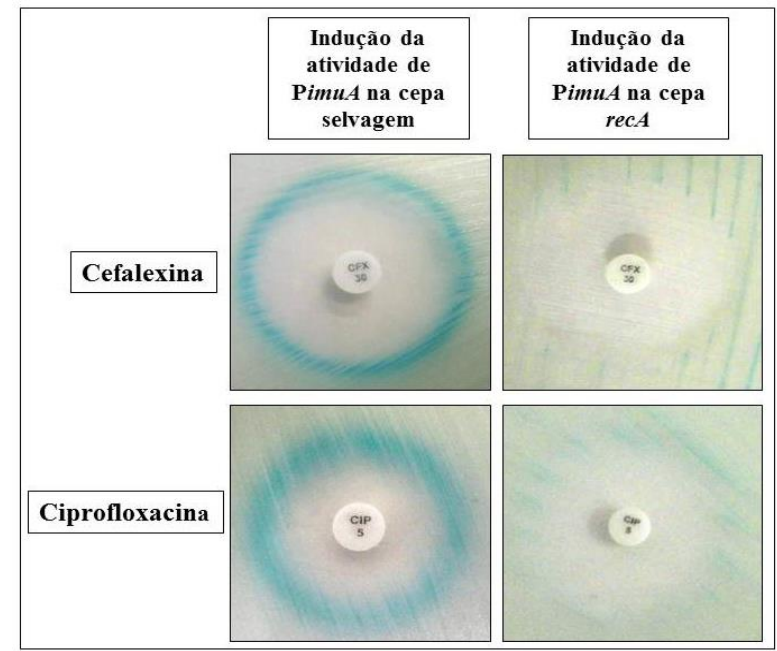

Halos de inibição em testes de disco-difusão, e indução da atividade dos promotores dos genes imuA em cepa construída no background selvagem e no background deficiente no gene recA frente a cefalexina e ciprofloxacina. Os halos de indução de coloração azulada devido à presença de X-gal no meio em ambas as imagens são referentes a concentrações subinibitórias de antibióticos. Os discos localizados na primeira linha referem-se à cefalexina (CFX) e os localizados na segunda linha à ciprofloxacina (CIP).

Neste trabalho, focamos em aprofundar o entendimento do papel da cefalexina na indução da resposta SOS em $C$. crescentus, e também as consequências biológicas desta indução. Pode- se obervar na Figura 22 que indução do promotor ImuA pela cefalexina é 
totalmente abolida na cepa deficiente em $\operatorname{rec} A$, confirmando que a indução por este antibiótico é dependente da resposta SOS. Os mesmos resultados foram obtidos para a ciprofloxacina, um antibiótico da classe das quinolonas, que é um conhecido indutor da resposta SOS.

Além da cefalexina, outros antibióticos beta-lactâmicos testados também resultaram em indução do regulon SOS em concentrações subinibitórias, são eles: ceftriaxona, piperacilina + tazobactam, imipenem e amoxicilina + ácido clavulânico (Figura 23). Em E.coli a indução da resposta SOS mediada por antibióticos beta-lactâmicos também foi demonstrada. Estudos realizados por Miller e colaboradores (2004) mostraram que antibióticos lactâmicos induziram a resposta SOS em E.coli, por meio de um sistema de transdução de sinal de dois complementos denominado DpiAB (MILLER et al., 2004). Plata e colaboradores (2013) mostraram recentemente que antibióticos beta-lactâmicos também resultam na indução da resposta SOS em S. Aureus. Segundo estes pesquisadores,os betalactâmicos comprometem a função da proteína PBP1, o que resulta em parada da divisão celular e, consequente indução do regulon SOS.

Por outro lado, outros antibióticos beta-lactâmicos não resultaram em indução deste regulon em C. crescentus, como: aztreonama, cefepime, ceftazidima e cefalotina (Figuras 23 e 24). Esta diferença provavelmente se deva às diferentes PBPs que são alvo de cada um destes antimicrobianos. Entretanto, estudos sobre a interação de beta-lactâmicos com PBPs em $C$. crescentus ainda não foram realizados, de forma que não é possível correlacionar a indução do regulon SOS em C. crescentus com a inibição de uma PBP em particular. C. crescentus apresenta 14 diferentes PBPs relacionadas com beta-lactâmicos (NATHAN; NEWTON, 1988). Além disto, estudos demonstraram que o antibótico beta-lactâmico penicilina $G$ apresenta afinidade superior à proteína PBP1B em relação às demais PBPs presentes em $C$. crescentus (NATHAN; NEWTON, 1988). Provavelmente, diferentes antimicrobianos interagem com maior afinidade a determinadas PBPs, o que justificaria nossos resultados de indução do regulon SOS por determinados antimicrobianos, e não indução por outros.

Nossos resultados demonstraram também que vários outros antibióticos pertencentes a diferentes classes não induziram a resposta SOS em C. crescentus. Assim como demonstrado previamente para E.coli (PEREZ-CAPILLA et al., 2005; SHAW et al., 2003), nossos dados mostraram que os antimicrobianos cloranfenicol, amicacina, eritromicina, rifampicina e doxiciclina não desencadearam a resposta SOS em C. crescentus (Figuras 23 e 24). Por outro 
lado, estudos realizados em Vibrio cholerae demonstraram que aminoglicosídeos e rifampicina são indutores da resposta SOS (BAHAROGLU; MAZEL, 2011). Além disto, o antibiótico trimetoprima foi descrito como um indutor da resposta SOS em E. coli (SHAW et al., 2003), o que não foi observado neste trabalho para C. crescentus (Figura 23). Estes dados em conjunto demonstram que a indução do regulon SOS mediada por antibióticos é bastante variável entre diferentes microorganismos e antibióticos.

\section{Figura 23 - Testes de disco-difusão e a indução da atividade de PimuA frente a diferentes compostos antimicrobianos}

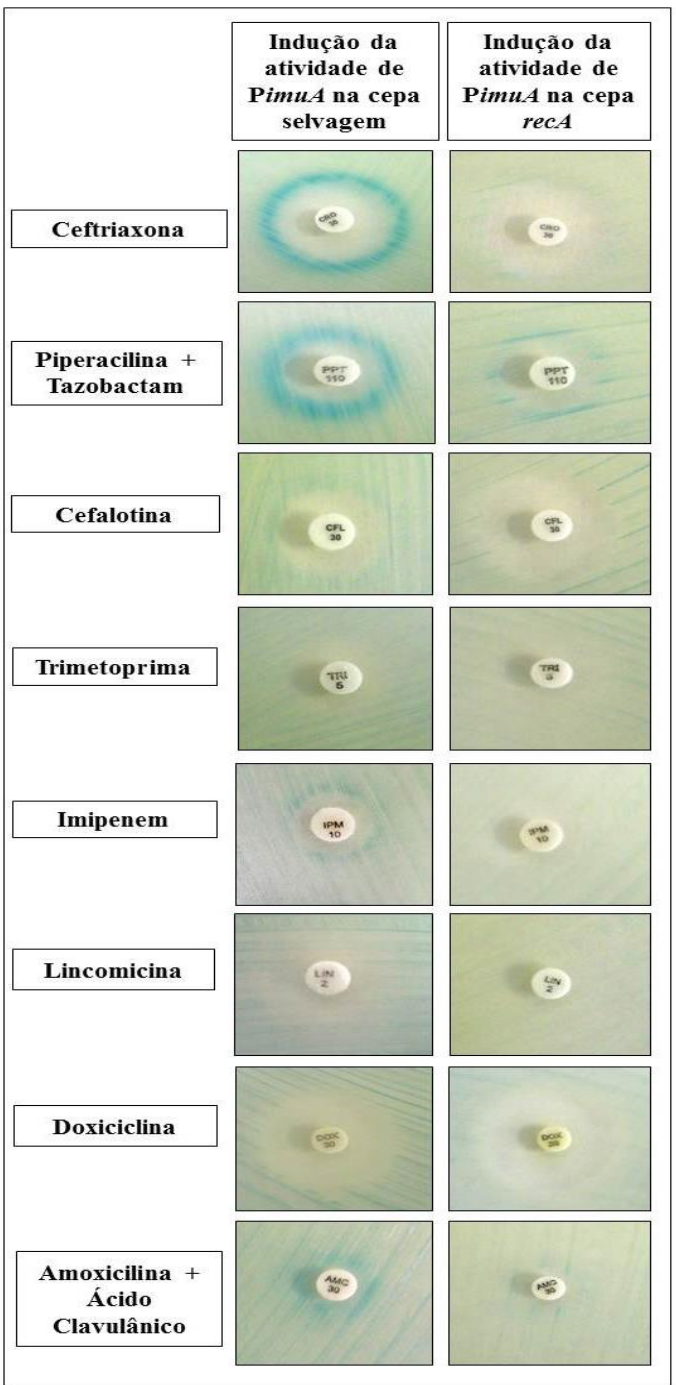

Halos de inibição em testes de disco-difusão, mostrando a atividade do promotor do gene imuA em cepa construída no background selvagem e no background deficiente no gene $r e c A$, frente a diferentes antibióticos. Os halos de indução de coloração azulada devido à presença de X-gal no meio em ambas as imagens são referentes a concentrações subinibitórias de antibióticos. Os discos testados referem-se à ceftriaxona (CRO), piperacilina + tazobactam (PPT), cefalotina (CFL), trimetoprima (TRI), imipenem (IPM), lincomicina (LIN), doxiciclina (DOX) e amoxicilina + ácido clavulânico (AMC). 


\section{Figura 24 - Testes de disco-difusão e a indução da atividade de PimuA frente a diferentes compostos antimicrobianos}

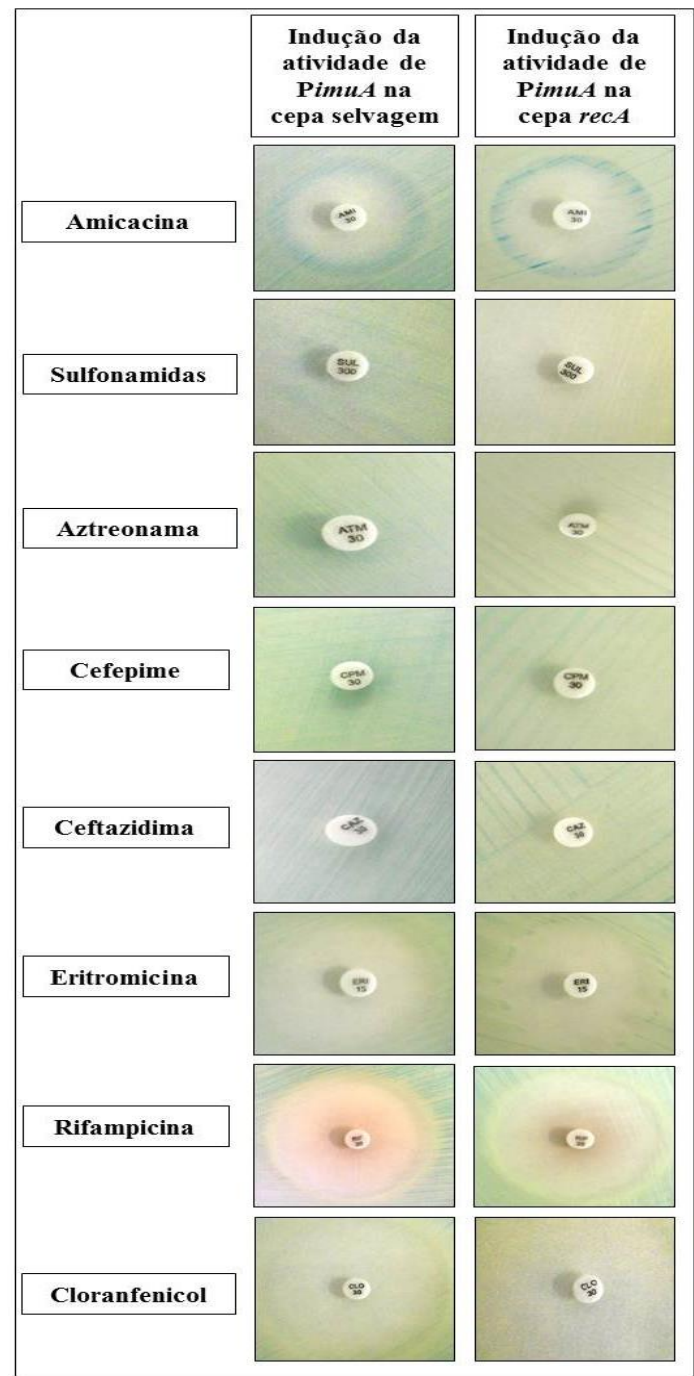

Halos de inibição em testes de disco-difusão, mostrando a atividade do promotor do gene imuA em cepa construída no background selvagem e no background deficiente no gene recA, frente a diferentes antibióticos. Os halos de indução de coloração azulada devido à presença de X-gal no meio em ambas as imagens são referentes a concentrações subinibitórias de antibióticos. Os discos testados referem-se à amicacina (AMI), sulfonamidas (SUL), aztreonama (ATM), cefepime (CPM), ceftazidima (CAZ), eritromicina (ERI), rifampicina (RIF) e cloranfenicol (CLO).

\subsubsection{Ensaios de beta-galactosidade}

Nosso próximo passo foi confirmar a indução do regulon SOS por cefalexina através do ensaio quantitativo de atividade de Beta-galactosidase, visto que esta indução foi demostrada somente por ensaios qualitativos de disco-difusão (Figura 22). 
Primeiramente, realizamos ensaios a fim de estabelecer a concentração máxima de cefalexina tolerada por $C$. crescentus nestas condições experimentais, ficando estabelecida a concentração de $6 \mu \mathrm{g} / \mathrm{ml}$ deste antibiótico. Concentrações superiores a este valor resultam em uma severa diminuição na velocidade de crescimento, o que impossibilita a comparação da atividade de lacZ com as culturas não tratadas. Portanto, utilizamos neste ensaio as concentrações de 5 e $6 \mu \mathrm{g} / \mathrm{ml}$ de cefalexina, e as atividades de lac $Z$ foram avaliadas até 540 minutos de cultivo. A Figura 25 mostra que nestas condições, a concentração subinibitória de $6 \mu \mathrm{g} / \mathrm{ml}$ resulta em uma indução máxima de aproximadamente duas vezes, após 360 minutos de exposição à cefalexina, comparando-se com as células não tratadas.

\section{Figura 25 - Efeito da cefalexina na expressão do promotor de imuA e no crescimento de C. crescentus.}

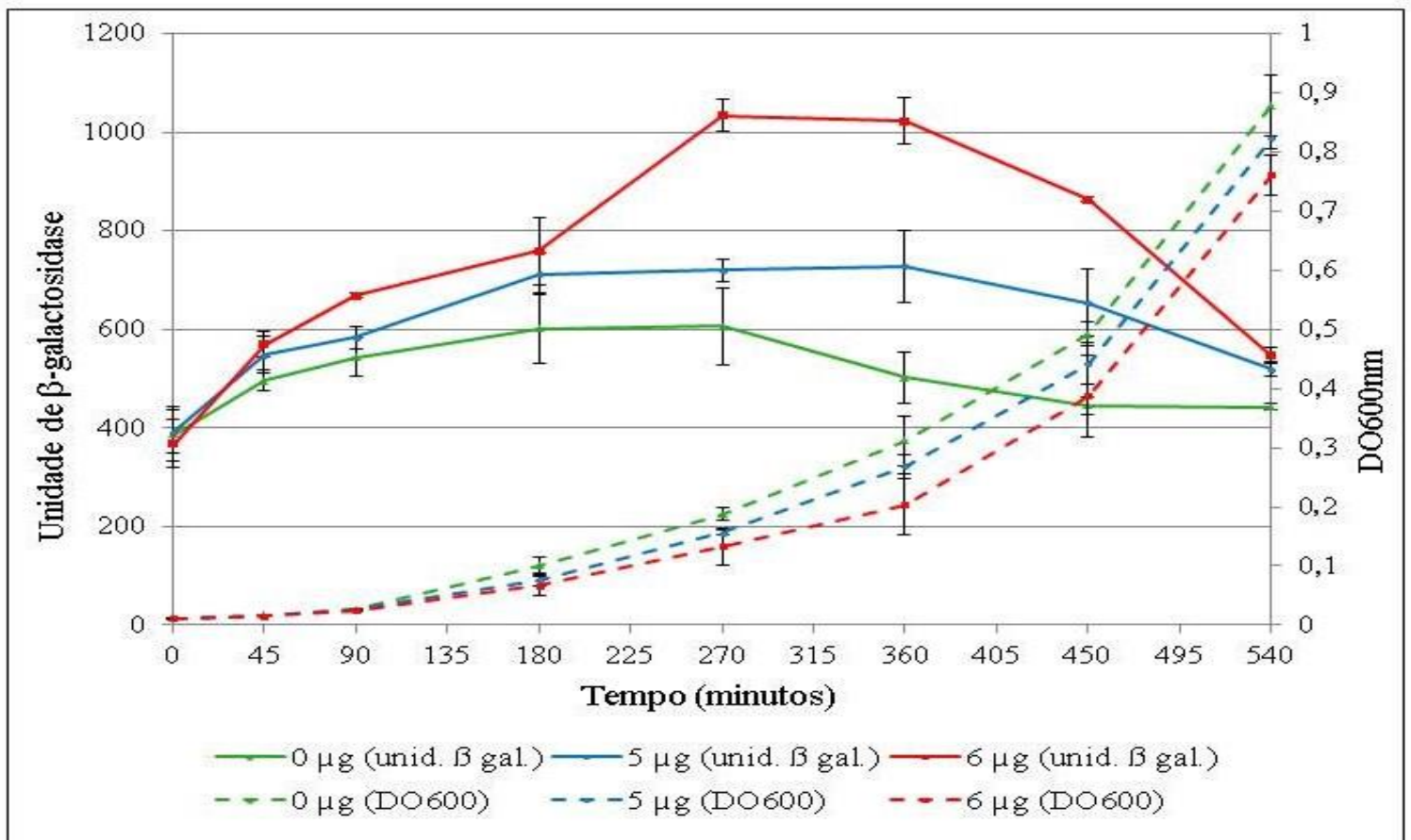

Concentrações de cefalexina $(5$ e $6 \mu \mathrm{g} / \mathrm{ml})$ foram acrescidas em células contendo a construção PimuAlacZ, e o crescimento e a atividade Beta-galactosidase foram aferidos em vários pontos ao longo do cultivo. É possível observar que ao tratarmos as células com $6 \mu \mathrm{g} / \mathrm{ml}$ de cefalexina, obtivemos uma indução máxima do Sistema SOS de aproximadamente 2 vezes em relação à células não tratadas, após 360 minutos de crescimento. Os resultados representam a média de três experimentos independentes.

Os resultados obtidos no ensaio quantitativo de beta-galactosidase condizem com os dados verificados nos ensaios qualitativos de disco difusão. Ambos os ensaios comprovam que, de fato, concentrações subinibitórias de cefalexina promovem a indução da resposta SOS em C. crescentus. 
3.2.3 Ensaios de determinação da concentração inibitória mínima para cefalexina

A próxima abordagem neste trabalho foi avaliar o papel da resposta SOS e de outras vias de reparo de DNA na resistência intrínseca à cefalexina em $C$. crescentus. Para esta análise, determinamos a concentração inibitória mínima deste antibiótico para a cepa NA1000 e mutantes nos genes recA, dnaE2, oxyR, uvrA, mutY, mutM e dinB. O regulon oxyR apresenta genes envolvidos na defesa antioxidante celular importantes para resposta frente a estresses oxidativos. oxyR é o regulador positivo deste regulon, e o mutante oxyR de $C$. crescentus é sensível a agentes oxidantes (ITALIANI et al., 2011).

Os resultados do ensaio de CIM encontram-se na Tabela 7. Pode-se observar que a cepa mutante $\operatorname{rec} A$ não apresentou diferenças significativas na sensibilidade à cefalexina em relação a cepa selvagem NA1000. Este dado indica que a indução da resposta SOS pela cefalexina observada nos ensaios de beta-galactosidase (Figura 25) não é suficiente para promover uma tolerância maior aos danos induzidos por este antibiótico nas células.

\section{Tabela 7 - Determinação da concentração inibitória mínima de cefalexina para diferentes cepas de $C$. crescentus}

\begin{tabular}{|c|c|c|c|}
\hline Cepa & $\begin{array}{c}\text { CIM }(\mu \mathrm{g} / \mathrm{ml}) \\
24 \text { horas } \\
\text { incubação }\end{array}$ & $\begin{array}{c}\text { CIM }(\mu \mathrm{g} / \mathrm{ml}) \\
48 \text { horas } \\
\text { incubação }\end{array}$ & $\begin{array}{c}\text { CIM }(\mu \mathrm{g} / \mathrm{ml}) \\
72 \text { horas } \\
\text { incubação }\end{array}$ \\
\hline NA1000 & 8 & 11 & 18 \\
\hline recA & 8 & 10 & 17 \\
\hline dnaE2 & 8 & 10 & 12 \\
\hline oxyR & 6 & 8 & 11 \\
\hline uvrA & 3 & 5 & 11 \\
\hline$m u t Y$ & 7 & 10 & 16 \\
\hline mutM & 7 & 10 & 15 \\
\hline $\operatorname{din} B$ & 6 & 8 & 13 \\
\hline
\end{tabular}

As cepas de $C$. crescentus foram crescidas em concentrações crescentes de cefalexina. As leituras foram realizadas após os períodos de incubações de 24, 48 e 72 horas. O valor de CIM considerado foi a menor concentração de antibiótico capaz de inibir visualmente o crescimento bacteriano. Os dados mostram que cepas deficientes nos genes $\operatorname{dnaE2}$, uvrA, oxyR e $\operatorname{din} B$ são mais sensíveis à cefalexina em relação à cepa selvagem. 
A cepas mutantes mutY e mutM também não apresentaram diferenças significativas de sensibilidade à cefalexina em relação à cepa selvagem. O genes mutY e mutM atuam em conjunto prevenindo os efeitos mutagênicos desencadeados pela lesão oxidativa 8-oxoG. A glicosilase MutY atua removendo a adenina pareada erroneamente com 8-oxoG e MutM reconhece e remove a base 8-oxoG. Considerando que esta lesão é altamente mutagênica, mas pouco citotóxica para células, não esperávamos observar diferenças significativas nos valores de CIM das cepas mutantes mutY e mutM em relação a cepa NA1000, o que condiz com o resultado obtido.

Os dados mostram também, que as cepas deficientes nos genes $u v r A$, dnaE2 e $\operatorname{din} B$ apresentam maior sensibilidade à cefalexina após 72 horas de crescimento em relação à cepa selvagem, indicando que este antibiótico induz a formação de lesões no DNA, e que o reparo destas lesões envolve a participação das vias NER e síntese translesão, mediadas por estes genes.

A cepa $o x y R$ também apresenta um CIM inferior à cefalexina em relação à cepa selvagem, indicando que a cefalexina pode atuar induzindo danos oxidativos no DNA de $C$. crescentus. Antibióticos bactericidas, incluindo beta-lactâmicos geram estresse oxidativo altamente deletério em bactérias gram negativas e positivas, o que pode contribuir para a morte celular (KOHANSKI et al., 2007). Além disto, foi demostrado que estes antibióticos beta-lactâmicos e quinolonas resultam em quebras de dupla fita no DNA, devido à reparação incompleta de lesões oxidativas 8-oxoG (FOTI et al., 2012). Portanto, a cefalexina pode estar induzindo a formação de lesões oxidativas no DNA, o que justifica a maior sensibilidade à cefalexina nestes mutantes deficientes em genes de reparo.

\subsubsection{Mutagênese induzida por cefalexina}

Após determinarmos os valores que CIM para diferentes mutantes, o próximo passo foi avaliar se concentrações subinibitórias de cefalexina indutoras de resposta SOS apresentam efeito nas taxas de mutação em C. crescentus. Nestes ensaios, utilizamos sempre a concentração de cefalexina máxima tolerada para cada cepa em 48 horas de crescimento (considerando os valores de CIM determinados previamente), sempre utilizando um controle com a cepa selvagem cultivada nas mesmas condições. Logo, as cepas mutantes recA, dnaE2, mutY e mutM foram cultivadas com concentração de $8 \mu \mathrm{g} / \mathrm{ml}$ de cefalexina; a cepa $u v r A$ com 
concentração de $4 \mu \mathrm{g} / \mathrm{ml}$ e a cepa $\operatorname{oxy} R$ com $7 \mu \mathrm{g} / \mathrm{ml}$ deste antibiótico, e a mutagênese foi investigada através de testes de flutuação utilizando o marcador de resistência a rifampicina. Para estes ensaios não utilizamos o marcador de resistência a ampicilina xylbla, visto que este cassete codifica uma beta-lactamase que pode inativar antibióticos beta-lactâmicos, e com isso resultar em dados não confiáveis. A Figura 26 mostra os resultados obtidos nestes ensaios.

Pode-se observar que as taxas de mutação no gene $r p o B$ não variam significativamente na cepa selvagem após o tratamento com cefalexina. Este dado difere do observado para $E$. coli, que apresentou aumento na mutagênese após tratamento com antibióticos, incluindo beta-lactâmicos (KOHANSKI; DEPRISTO; COLLINS, 2010). As cepas deficientes nos genes $\operatorname{xxy} R$ e $u v r A$ não apresentaram diferenças significativas nas taxas de mutação em relação à cepa selvagem, sugerindo que estes genes não participam na prevenção de danos pré-mutagênicos no DNA induzidos por cefalexina, apesar de atuarem na prevenção da toxicidade causada por esta droga (Tabela 7). A cepa mutante recA também não apresentou aumento na mutagênese em relação à cepa selvagem, indicando que genes regulados pela resposta SOS não estão envolvidos com a mutagênese associada a antibióticos.

Além disto, a cepa mutante dnaE2 também não apresentou variação significativa na taxa de mutação. Estes dados diferem dos resultados obtidos no modelo E. coli em estudos prévios, no qual foi demonstrado que polimerases alternativas apresentam papel na mutagênese induzida por antibióticos beta-lactâmicos (KOHANSKI et al., 2007; GUTIERREZ et al., 2012). Realizamos também alguns ensaios preliminares de mutagênese com a cepa mutante para o gene que codifica a polimerase alternativa DinB (dados não mostrados), e também não foi verificado aumento na mutagênese induzida por concentrações subinibitórias de cefalexina. Estes dados em conjunto indicam que, diferentemente de E.coli, DNA polimerases alternativas envolvidas na síntese translesão não participam da mutagênese induzida por cefalexina em C. crescentus.

As cepas deficientes em mutY e mutM apresentaram aumento significativo na mutagênese de cerca de 3 e 2 vezes, respectivamente $(p=0,0209$ e $p=0,0490)$ em relação ao respectivo controle não tratado com antibiótico, após tratamento com concentrações subinibitórias de cefalexina (Figura 26). Como os genes mutY e mutM atuam de maneira específica no reparo do dano oxidativo 8-oxoG, pode-se concluir que concentrações subinibitórias de cefalexina induzem estresse oxidativo e formação destas lesões no DNA de 
C. crescentus. Esta conclusão condiz com o fenótipo de maior sensibilidade à cefalexina observada para as cepas mutantes oxyR e uvrA em ensaios de CIM. Nossos resultados demonstram, portanto, que em $C$. crescentus o aumento de mutagênese foi restrito a cepas deficientes em genes de reparo, como os mutantes mutM e mutY, possivelmente atribuído a danos no DNA, e não a um aumento da expressão de polimerases da família Y.

Figura 26 - Efeito das deleções gênicas em $\operatorname{dnaE2,~mutM,~mutY,~recA,~uvrA~e~oxyR~na~}$ mutagênese induzida por cefalexina em $C$. crescentus
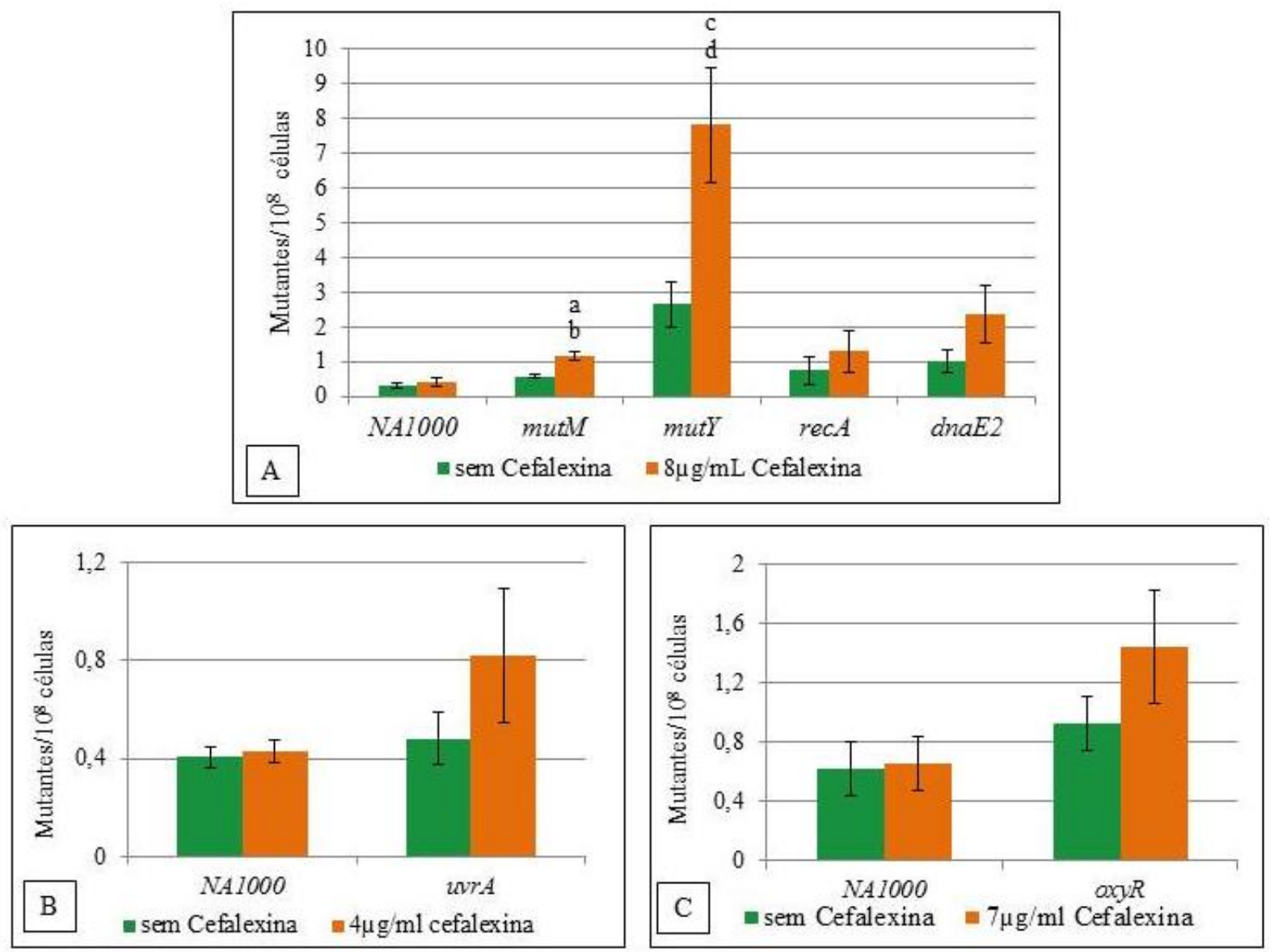

As células foram crescidas na presença de concentrações subinibitórias de cefalexina para ensaios de flutuação utilizando o marcador $r p o B\left(\mathrm{Rif}^{\mathrm{R}}\right)$. Os resultados representam média de três experimentos independentes. Estes dados mostram que há um aumento na mutagênese provocado pela presença de concentrações subinibitórias de cefalexina em $C$. crescentus deficientes nos gene de reparo mutM e mutY. Para a análise estatística foi utilizado o método de análise de variância não-paramétrico de Kruskal-Wallis e o teste de comparações mútiplas de Dunn, considerando $\mathrm{p}<0,05$. Na figura acima podem-se observar as diferenças significativas na mutagênese entre: (a) cepa mutante mutM e cepa parental crescidas com cefalexina; (b) cepa mutante mutM e seu respectivo controle não tratado com cefalexina; (c) cepa mutante mut $Y$ e cepa parental crescidas com cefalexina; (d) cepa mutante $m u t Y$ e seu respectivo controle não tratado com cefalexina. 
Pode-se observar também que as cepas mutantes mutY e mutM apresentaram mutagênese espontânea cerca de 7 e 3 vezes superior, respectivamente, em relação à cepa selvagem (Figura 26). Estes dados condizem com os resultados obtidos em E. coli, no qual foi demonstrado que a cepa mutante mutY apresenta níveis de mutagênese espontânea superiores à cepa mutante mutM (MICHAELS et al.,1992).

Porém, a magnitude do fenótipo mutador das cepas mutM e mut $Y$ em C. crescentus é muito menor do que o observado para os mesmos mutantes de E. coli. Contudo, nossos dados são semelhantes ao observado em Bacillus anthracis, onde mutantes para os genes mutY e mutM apresentaram mutagênese espontânea 8 e 2 vezes significantemente superiores em relação à cepa selvagem, respectivamente $(\mathrm{p}=0,0209 \mathrm{e} \mathrm{p}=0,0253)$. O mutante duplo mut $Y$ mutM em B. anthracis apresentou uma taxa de mutação espontânea extremamente elevada (cerca de 269 vezes em relação à cepa selvagem) (ZEIBELL et al., 2007). Estudos realizados em Pseudomonas aeruginosa demonstraram também que a deleção do gene mut $Y$ resulta em níveis superiores de mutações espontâneas em relação ao mutante mutM (SANDERS; SUDHAKARAN; SUTTON, 2009), assim como observamos em C. crescentus. A bactérias $P$. aeruginosa e $C$. crescentus são organismos com alto conteúdo $\mathrm{G}+\mathrm{C}$ no genoma, sendo consideravelmente mais susceptíveis a danos oxidativos do tipo 8-oxoG, e por isso o reparo desta lesão deve ser crucial para estas bactérias (JAIN; KUMAR; VARSHNEY, 2007; KURTHKOTI et al., 2010). Por outro lado, a deleção do gene mutY em Micobacterium smegmatis não afetou significantemente os níveis de mutagênese espontânea em relação à cepa parental, e o mutante mutM revelou um aumento moderado (cerca de 3 vezes) nas taxas de mutação neste bactéria (JAIN; KUMAR; VARSHNEY, 2007; KURTHKOTI et al., 2010). Desta forma, nossos dados, bem como outros presentes na literatura, sugerem que o modelo do sistema GO de E. coli pode não representar o cenário completo do reparo de 8-oxoG em outras bactérias, e possivelmente sistemas alternativos existem para a prevenção dos efeitos mutagênicos deste dano.

Czeczot e colaboradores (1991) demonstraram que a via NER apresenta participação no reparo de danos do tipo 8-oxoG em E.coli. Isto não foi verificado para C. crescentus, visto que a cepa mutante uvrA não apresentou aumento na taxa de mutação após exposição à cefalexina. Provavelmente, em C. crescentus a via NER esteja atuando em outros danos oxidativos induzidos em menores concentrações pela cefalexina, incluindo, por exemplo, danos do tipo timina glicol e formamidopirimidina. Isto justificaria a maior sensibilidade da 
cepa mutante $u v r A$ frente a tratamentos com cefalexina, apesar da ausência de mutagênese aumentada nesta cepa.

Diferentes situações indutoras de estresse oxidativo ocasionam a formação de distintos perfis de danos oxidativos. Tratamentos com luz UVA, por exemplo, resultam em um perfil de danos composto predominantemente por Fapy-dG (DIZDAROGLU et al.,2002).

Acreditamos que o estresse oxidativo gerado pela cefalexina resulta em um predomínio de lesões do tipo 8-oxoG e uma menor proporção de lesões do tipo Tg e Fapy em células de $C$. crescentus. Como as lesões Tg e Fapy induzem o bloqueio da replicação, estas supostamente atuam como indutoras do regulon SOS. Considerando que estas lesões sejam formadas em menor proporção pela cefalexina, teremos uma indução leve do sistema SOS e também uma maior sensibilidade a este antibiótico nas cepas mutantes para genes que atuam no reparo destas lesões. Esta hipótese explica os valores de CIM inferiores observados nas cepas mutantes $u v r A$, dnaE2 e oxyR em relação à cepa selvagem, bem como a moderada indução do regulon SOS.

Lesões do tipo 8-oxoG ocorrem com bastante frequência nas células, e por isso as células empregam distintos mecanismos para o reparo destas lesões. Além disto, observamos que as cepas mutantes simples mutY e mutM não apresentaram diferenças significativas nos valores de CIM em relação à cepa selvagem. Estes resultados são esperados, visto que as lesões 8-oxoG são consideradas pouco citotóxicas para as células. Ademais, observamos um aumento significativo na mutagênese induzida por cefalexina nas cepas $m u t Y$ e $m u t M$, o que é condizente com a formação destas lesões. A Figura 27 esquematiza nossa hipótese de indução da resposta SOS por concentrações subinibitórias de cefalexina.

Uma abordagem futura interessante para esta parte do trabalho será a realização de ensaios de mutagênese após exposição à cefalexina, utilizando a cepa mutante duplo mutM mutY. Como estes genes atuam conjuntamente evitando a mutagênese mediada por lesões 8oxoG no DNA, esperamos observar um fenótipo mutador extremamente acentuado neste duplo mutante, caso a cefalexina induza altos níveis desta lesão oxidativa no DNA. 
Figura 27 - Representação esquemática da indução da Resposta SOS por concentrações subinibitórias de cefalexina em $C$. crescentus

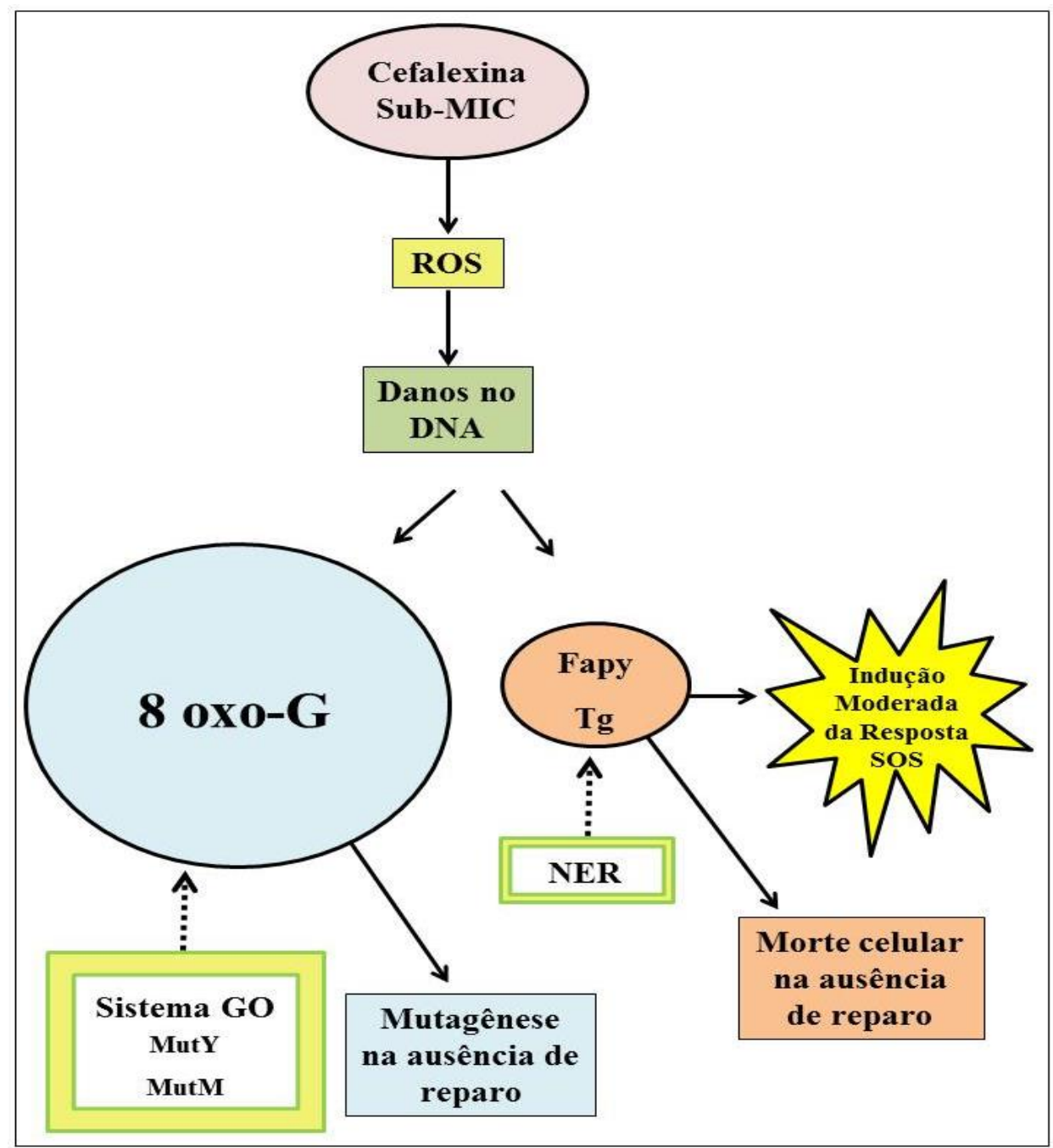

A cefalexina provavelmente gera estresse oxidativo celular que resultam na formação predominantemente de danos do tipo 8-oxoG no DNA. Os genes mutM e mutY, pertencentes ao sistema GO, apresentam um papel crucial evitando a mutagênese mediada por este dano oxidativo. Por outro lado, lesões citotóxicas Fapy e Tg são formadas em menores concentrações, e resultam na indução da resposta SOS em C. crescentus. O reparo destes danos provavelmente envolve a participação da via NER, ou outras glicosilases associadas à via BER.

\subsubsection{Ensaios de imuno-slot blot}

Realizamos também ensaios de imuno slot blot, visando uma confirmação molecular da indução de estresse oxidativo e formação de lesões 8-oxoG por concentrações subinibitórias de cefalexina. Para isto, utilizamos anticorpos específicos para a lesão 8-oxoG, considerando que este dano é um marcador indicativo de dano oxidativo celular. A cepa 
selvagem NA1000 foi cultivada com concentrações subinibitórias de cefalexina, determinadas previamente, e alíquotas foram retiradas 48 horas de incubação com este antibiótico.

Pode-se observar na Figura 28 que os DNAs expostos a concentrações subinibitórias de cefalexina apresentaram maiores níveis de lesões de 8-oxoG reconhecidas pelo anticorpo específico em relação às células não tratadas. Este dado condiz com os resultados obtidos nos outros experimentos, e sugere que concentrações subinibitórias deste antibiótico induzem a formação de lesões de 8-oxoG em C. crescentus.

Figura 28 - Determinação imunológica de lesões 8-oxoG no DNA de $C$. crescentus após tratamento cefalexina

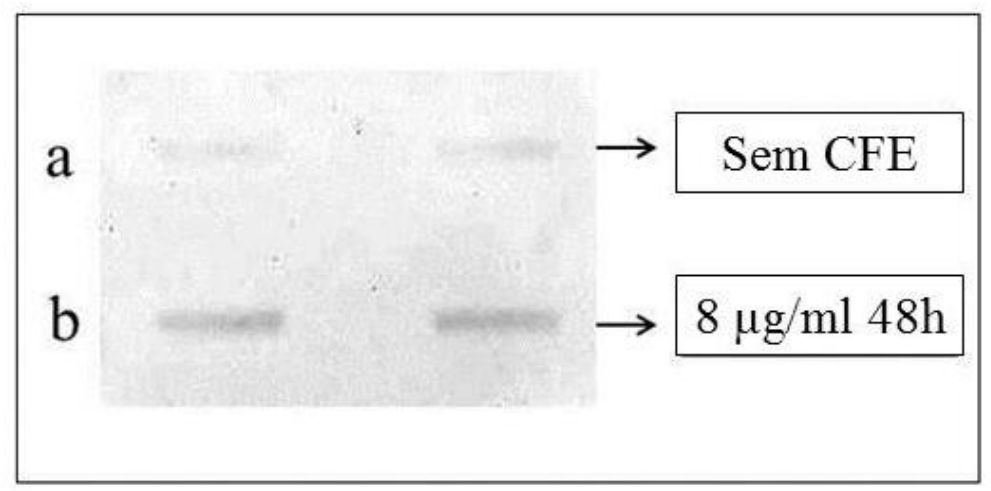

Amostras de DNAs foram coletadas 48 horas após as células serem tratadas com $8 \mu \mathrm{g} / \mathrm{ml}$ de cefalexina (b). Um controle não tratado com este antibiótico também foi utilizado (a). É possível observar uma maior concentração de danos 8-oxoG nas células tratadas com concentrações subinibitórias de cefalexina em relação as células não tratadas. Estes dados sugerem que a cefalexina gera estresse oxidativo celular, resultando em lesões do tipo 8-oxoG em C. crescentus. 


\section{CONCLUSÕES}

\subsection{Análise funcional de genes pertencentes ao regulon SOS}

- A cepa deficient no gene CC_0627 não apresentou fenótipo de sensibilidade frente aos agentes genotóxicos luz UV, MMS e MMC.

- A cepa deficiente no CC_2040 apresentou modesto fenótipo de sensibilidade à $\mathrm{H}_{2} \mathrm{O}_{2} \mathrm{e}$ MMC.

- As cepas deficientes nos genes CC_3424 e CC_3467 se mostraram consideravelmente mais sensíveis à MMC em relação à cepa parental.

- A tolerância à MMC mediada gene CC_3424 não depende das vias NER, TLS e recombinação homóloga, e possivelmente este gene atua detoxificando a MMC das células.

- O gene CC_3467 atua conjuntamente com a via TLS e com sobreposição parcial de função com NER no reparo de ICLs por MMC. Este gene possivelmente exerce atividade de endonulcease e apresenta papel no reparo de ICLs induzidas por MMC.

- Os genes CC_3467 e CC_3424 atuam em vias distintas para promover tolerância à MMC.

- A cepa duplo mutante CC_3467 recA se mostrou inviável, indicando uma interação genética do tipo sintética letal entre a via de recombinação e CC_3467.

\subsection{Efeitos biológicos da indução do sistema SOS por antibióticos beta-lactâmicos}

- Concentrações subinibitórias de cefalexina resultam em indução moderada da resposta SOS C. crescentus.

- Cepas deficientes nos genes $d n a E 2, o x y R, u v r A$ e dinB são ligeiramente mais sensíveis à cefalexina em relação a cepa selvagem.

- As cepas selvagem e deficiente no gene dnaE2 não apresentaram diferenças significativas na mutagênese após tratamento com concentrações subinibitórias de cefalexina 
- As cepas deficientes nos genes mutM e mutY apresentaram aumento na mutagênese após tratamento com concentrações subinibitórias de cefalexina.

- Ensaios de imuno slot blot mostraram que células tratadas com concentrações subinibitórias de cefalexina apresentam maior concentração de danos oxidativos do tipo 8-oxoG em relação as células não tratadas com este antibiótico. 


\section{REFERÊNCIAS $^{1}$}

AL MAMUN, A. A. M.; HUMAYUN, M. Z. Escherichia coli DNA polymerase II can efficiently bypass 3,N4-ethenocytosine lesions in vitro and in vivo Mutation Research/Fundamental and Molecular Mechanisms of Mutagenesis, v. 593, n. 1, p. 164176, 2006.

AUSUBEL, F. M.; BRENT, R.; KINGSTON, R. E.; MOORE, D. D.; SEIDMAN, J. G.; SMITH, J. A.; STRUHL, K. Escherichia coli, plasmids and bacteriophages. Short protocols in molecular biology. New York: John Wiley e Sons, 1999. p.5-9.

AUTRET, S.; LEVINE, A.; HOLLAND, I. B.; SERROR, S. J. Cell cycle checkpoints in Bacteria. Biochemie, v. 79, n. 9, p. 549-554, 1997.

AYRES, M.; AYRES, M. J.; AYRES, D. L.; SANTOS, A. S. Software Bioestat versão 5.3. Aplicações estatísticas nas áreas das ciências biomédicas. Belém, PA: Sociedade Civil Mamirauá; 2007.

BAHAROGLU, Z.; MAZEL, D. Vibrio cholerae Triggers SOS and Mutagenesis in Response to a Wide Range of Antibiotics: a Route towards Multiresistance. Antimicrobial Agents and Chemotherapy, v. 55, n. 5, p. 2438-2441, 2011.

BASU, A. K.; LOECHLER, E. L.; LEADON, S. A.; ESSIGMANN, J. M. Genetic effects of thymine glycol: site-specific mutagenesis and molecular modeling studies. Proceedings of the National Academy of Sciences, v. 86, n 20, p. 7677-7681, 1989.

BECHEREL, O. J.; FUCHS, R. P.; WAGNER, J. Pivotal role of the $\beta$-clamp in translesion DNA synthesis and mutagenesis in E. coli cells. DNA Repair, v.1, n.9, p. 703-708, 2002.

BERANEK, D. T. Distribution of methyl and ethyl adducts following alkylation with monofunctional alkylating agents. Mutation Research/Fundamental and Molecular Mechanisms of Mutagenesis, v. 231, n.1, p. 11-30, 1990.

BERARDINI, M.; FOSTER, P. L.; LOECHLER, E. L. DNA polymerase II (polB) is involved in a new DNA repair pathway for DNA interstrand cross-links in Escherichia coli. Journal of Bacteriology, v.181, n.9, p. 2878-2882, 1999.

BERGDOLL, M.; ELTIS, L. D.; CAMERON, A. D.; DUMAS, P.; BOLIN, J. T. All in the family: structural and evolutionary relationships among three modular proteins with diverse functions and variable assembly. Protein Science, v. 7, n. 8, p. 1661-1670, 1998.

BERNAT, B. A.; LAUGHLIN, L. T.; ARMSTRONG, R. N. Fosfomycin resistance protein (FosA) is a manganese metalloglutathione transferase related to glyoxalase I and the extradiol dioxygenases. Biochemistry, v. 36, n. 11, p. 3050-3055, 1997

\footnotetext{
${ }^{1}$ De acordo com: ASSOCIAÇÃO BRASILEIRA DE NORMAS TÉCNICAS. NBR 6023: informação e documentação: referências: elaboração. Rio de Janeiro, 2002.
} 
BOS, J.; YAKHNINA, A. A.; GITAI Z. BapE DNA endonuclease induces an apoptotic-like response to DNA damage in Caulobacter. Proceedings of the National Academy of Sciences, v. 109, n. 44, p. 18096-18101, 2012.

BOSHOFF, H. I.; REED, M. B.; BARRY, C. E.; MIZRAHI, V. DnaE2 Polymerase Contributes to In Vivo Survival and the Emergence of Drug Resistance in Mycobacterium tuberculosis. Cell, v.113, n. 2, p.183-193, 2003.

BROSH JR, R. M. DNA helicases involved in DNA repair and their roles in cancer. Nature Reviews Cancer, v. 13, n. 8, p. 542-558, 2013.

BURROWS, C. M.; MULLER, J. Oxidative Nucleobase Modifications Leading to Stand Scission. Chemical Reviews, v. 98, n. 3, p. 1109-1152, 1998

BUTALA, M.; ZGUR-BERTOK, D.; BUSBY, S. J. The bacterial LexA transcriptional repressor. Cellular and Molecular Life Sciences, v. 66, n. 1, p. 82-93, 2009.

BUTALA, M.; KLOSE, D.; HODNIK, V.; REMS, A.; PODLESEK, Z.; KLARE, J. P.; ANDERLUH, G.; BUSBY, S. J. W.; STEINHOFF, H. J.; ZGUR-BERTOK, D. Interconversion between bound and free conformations of LexA orchestrates the bacterial SOS response. Nucleic Acids Research, v. 39, n. 15, p. 6546-6557, 2011.

CHAMBERS H. F. Antibióticos beta-lactâmicos e outros inibidores da síntese de parede celular: compostos beta-lactâmicos. In: KATZUNG, B. (Ed.). Farmacologia: básica e clínica. Rio de Janeiro, Brasil: Guanabara Koogan, 2003. p. 256.

CHANDRASEKHAR, D.; VAN HOUTEN, B. In vivo formation and repair of cyclobutane pyrimidine dimers and 6-4 photoproducts measured at the gene and nucleotide level in Escherichia coli. Mutation Research/Fundamental and Molecular Mechanisms of Mutagenesis, v.450, n.1, p. 19-40, 2000.

CIRZ, R. T.; CHIN, J. K.; ANDES, D. R.; DE CRECY-LAGARD, V.; CRAIG, W. A.; ROMESBERG, F. E. Inhibition of mutation and combating the evolution of antibiotic resistance. PLOS Biology,v.3, n. 3, p.e176, 2005.

CIRZ, R. T.; ROMESBERG, F. E. Induction and inhibition of ciprofloxacin resistanceconferring mutations in hypermutator bacteria. Antimicrobial Agents and Chemotherapy, v. 50, n. 1, p. 220-225, 2006.

CLANCY, S. DNA damage e repair: mechanisms for maintaining DNA integrity. Nature Education, v. 1, n. 1, p.103, 2008.

COOPER, V. S.; LENSKI, R. E. The population genetics of ecological specialization in evolving Escherichia coli populations. Nature, v. 407, n. 6805, p. 736-739, 2000.

COURCELlE, J.; KHODURSKY, A.; PETER, B.; BROWN, P. O.; HANAWALT, P. C. Comparative gene expression profiles following UV exposure in wild-type and SOS-deficient Escherichia coli. Genetics, v. 158, n. 1, p. 41-64, 2001. 
CROWLEY, D. J.; COURCELLE, J. Answering the call: coping with DNA damage at the most inopportune time. Journal of Biomedicine and Biotechnology, v. 2, n. 2, p. 66-74, 2002.

CZECZOT, H.;TUDEK, B.; LAMBERT, B.; LAVAL, J.; BOITEUX, S. Escherichia coli Fpg protein and UvrABC endonuclease repair DNA damage induced by methylene blue plus visible light in vivo and in vitro. Journal of Bacteriology, v. 173, n. 11, p. 3419-3424, 1991.

DA ROCHA, R. P.; DE MIRANDA PAQUOLA, A. C.; DO VALLE MARQUES, M.; MENCK, C. F. M.; GALHARDO, R. S. Characterization of the SOS regulon of Caulobacter crescentus. Journal of Bacteriology, v. 190, n. 4, p. 1209-1218, 2008.

DAVID, S. S.; O'SHEA, V. L.; KUNDU, S. Base-excision repair of oxidative DNA damage. Nature, v. 447, n. 7147, p. 941-950, 2007.

DE LAAT, W. L.; JASPERS, N. G.; HOEIJMAKERS, J. H. Molecular mechanism of nucleotide excision repair. Genes and Development, v. 13, n. 7, p. 768-785, 1999.

DELANEY, S.; NEELEY, W. L.; DELANEY, J. C.; ESSIGMANN, J. M. The substrate specificity of MutY for hyperoxidized guanine lesions in vivo. Biochemistry, v. 46, n. 5, p. 1448-1455, 2007.

DEMPLE, B.; HARRISON, L. Repair of oxidative damage to DNA: enzymology and biology. Annual Review of Biochemistry, v. 63, n. 1, p. 915-948, 1994.

DENAMUR, E.; MATIC, I. Evolution of mutation rates in bacteria. Molecular Microbiology, v. 60, n. 4, p. 820-827, 2006.

DIANOV, G.; PRICE, A.; LINDAHL, T. Generation of single-nucleotide repair patches following excision of uracil residues from DNA. Molecular and Cellular Biology, v. 12, n. 4, p. 1605-1612, 1992.

DIANOV, G. L.; THYBO, T.; DIANOVA, I. I.; LIPINSKI, L. J.; BOHR, V. A. Single nucleotide patch base excision repair is the major pathway for removal of thymine glycol from DNA in human cell extracts. Journal of Biological Chemistry, v. 275, n. 16, p. 1180911813, 2000.

DIZDAROGLU, M.; JARUGA, P.; BIRINCIOGLU, M.; RODRIGUEZ, H. Free radicalinduced damage to DNA: mechanisms and measurement. Free Radical Biology and Medicine, v. 32, n. 11, p. 1102-1115, 2002.

DO THI, T.; LO’PEZ, E.; RODRI'GUEZ-ROJAS, A.; RODRI'GUEZ-BELTRA`N, J.; COUCE, A.; GUELFO, J. R.; CASTANEDA-GARCI'A, A.; BLA'ZQUEZ, J.. Effect of recA inactivation on mutagenesis of Escherichia coli exposed to sublethal concentrations of antimicrobials. Journal of Antimicrobial Chemotherapy, v. 66, n. 3, p. 531-538, 2011.

DRLICA, K.; ZHAO, X. DNA gyrase, topoisomerase IV, and the 4-quinolones. Microbiology and Molecular Biology Reviews, v. 61, n. 3, p. 377-392, 1997. 
DWYER, D. J.; KOHANSKI, M. A.; COLLINS, J. J. Role of reactive oxygen species in antibiotic action and resistance. Current Opinion in Microbiology, v. 12, n. 5, p. 482-489, 2009.

ELY, B. Genetics of Caulobacter crescentus. Methods in Enzymology, v. 204, p. 372-384, 1991.

ERILL, I.; CAMPOY, S.; MAZON, G.; BARBE, J. Dispersal and regulation of an adaptive mutagenesis cassette in the bacteria domain. Nucleic Acids Research, v. 34, n. 1, p. 66-77, 2006.

ERILL, I.; CAMPOY, S.; BARBÉ, J. Aeons of distress: an evolutionary perspective on the bacterial SOS response. FEMS Microbiology Reviews, v. 31, n. 6, p. 637-656, 2007.

EVINGER, M.; AGABIAN, N. Envelope-associated nucleoid from Caulobacter crescentus stalked and swarmer cells. Journal of Bacteriology, v. 132, n. 1, p. 294-301, 1977.

FEIERBERG, I.; CAMERON, A., D.; ÅQVIST, J. Energetics of the proposed ratedetermining step of the glyoxalase I reaction. FEBS letters, v. 453, n.1, p. 90-94, 1999.

FERNÁNDEZ DE HENESTROSA, A. R.; OGI, T.; AOYAGI, S.; CHAFIN, D.; HAYES, J. J.; OHMORI, H.; WOODGATE, R. Identification of additional genes belonging to the LexA regulon in Escherichia coli. Molecular Microbiology, v. 35, n. 6, p. 1560-1572, 2000.

FOTI, J. J.; DEVADOSS, B.; WINKLER, J. A.; COLLINS, J. J.; WALKER, G. C. Oxidation of the guanine nucleotide pool underlies cell death by bactericidal antibiotics. Science, v.336, n. 6079 , p. 315-319, 2012.

FRIEDBERG, E. C., G. C. WALKER, W. SIEDE, R. D. WOOD, R. A. SCHULTZ, AND T. ELLENBERGER. DNA Repair and Mutagenesis. ASM Press, Washington D. C, 2006.

FUCHS R. P.; FUJII, S. Translesion DNA synthesis and mutagenesis in prokaryotes. Cold Spring Harbor Perspectives in Biology, v. 1, n. 5, p. a012682, 2013.

FUJII, S.; GASSER, V.; FUCHS, R. P. The biochemical requirements of DNA polymerase Vmediated translesion synthesis revisited. Journal of Molecular Biology, v. 341, n. 2, p. 405417, 2004.

FURDA, A. M.; BESS, A. S.; MEYER, J. N.; VAN HOUTEN, B. Analysis of DNA damage and repair in nuclear and mitochondrial DNA of animal cells using quantitative PCR. In DNA Repair Protocols. Humana Press, 2012. p. 111-132.

GALHARDO, R. S.; ROCHA R. P.; MARQUES, M. V.; MENCK, C. F. An SOS-regulated operon involved in damage-inducible mutagenesis in Caulobacter crescentus. Nucleic Acids Research, v. 33, n. 8, p. 2603-2614, 2005.

GALHARDO, R. S.; HASTINGS, P. J.; ROSENBERG, S. M. Mutation as a stress response and the regulation of evolvability. Critical Reviews in Biochemistry and Molecular Biology, v. 42, n. 5, p. 399-435, 2007. 
GOBER, J. W.; SHAPIRO, L. A developmentally regulated Caulobacter flagellar promoter is activated by 3' enhancer and IHF binding elements. Molecular Biology of the Cell, v. 3, n. 8, p. 913-926, 1992.

GROLLMAN, A. P.; MORIYA M. Mutagenesis by 8-oxoguanine: an enemy within. Trends in Genetics, v. 9, n. 7, p. 246-249, 1993.

GUTIERREZ, A.; LAURETI, L.; CRUSSARD, S.; ABIDA, H.; RODRIGUEZ-ROJAS, A., BLAZQUEZ, J.; BAHAROGLU, Z.; MAZEL, D.; DARFEUILLE, F.; VOGE, J.; MATIC, I. B-lactam antibiotics promote bacterial mutagenesis via an RpoS-mediated reduction in replication fidelity. Nature Comunications, v. 4, p. 1610, 2012

HALLIWELL, B. Oxygen and nitrogen are pro-carcinogens. Damage to DNA by reactive oxygen, chlorine and nitrogen species: measurement, mechanism and the effects of nutrition. Mutation Research/Genetic Toxicology and Environmental Mutagenesis, v. 443, n. 1, p. 37-52, 1999.

HANAHAN, D. Studies on transformation of Escherichia coli with plasmids. Journal of Molecular Biology, v. 166, n. 4, p. 557-580, 1983.

HENDERSON, P. T.; DELANEY, J. C.; MULLER, J. G.; NEELEY, W. L.; TANNENBAUM, S. R.; BURROWS, C. J.; ESSIGMANN, J. M. The hydantoin lesions formed from oxidation of 7,8-dihydro-8-oxoguanine are potent sources of replication errors in vivo. Biochemistry, v. 42, n. 31, p. 9257-9262, 2003.

HINZ, J. M. Role of homologous recombination in DNA interstrand crosslink repair. Environmental and Molecular Mutagenesis, v. 51, n. 6, p. 582-603, 2010.

HOFHEINZ, R. D.; BEYER, U.; AL-BATRAN, S. E.; HARTMANN, J. T. Mitomycin C in the treatment of gastrointestinal tumours: recent data and perspectives. Onkologie, v. 31, n. 5, p. $271-281,2008$.

HUISMANM, O.; D'ARI, R.; GOTTESMAN, S. Cell division control in Escherichia coli: specific induction of the SOS function SfiA protein is sufficient to block septation. Proceedings of the National Academy of Sciences, v. 81, n. 14, p. 4490-4494, 1984.

INDIANI, C.; O'DONNELL, M. A proposal: Source of single strand DNA that elicits the SOS response. Frontiers in Bioscience, v. 18, p. 312-323, 2013.

ITALIANI, V.; ZULETA, L. F. G.; MARQUES, M. V. The transcription termination factor Rho is required for oxidative stress survival in Caulobacter crescentus. Molecular Microbiology, v. 44, n. 1, p. 181-194, 2002.

ITALIANI, V. C.; SILVA NETO, J. F.; BRAZ, V. S.; MARQUES, M.V. Regulation of catalase-peroxidase KatG is OxyR-dependent and Fur-independent in Caulobacter crescentus. Journal of Bacteriology, v. 193, n. 7, p. 1734-1744, 2011.

JAIN, R.; KUMAR, P.; VARSHNEY, U. A distinct role of formamidopyrimidine DNA glycosylase (MutM) in down-regulation of accumulation of $\mathrm{G}, \mathrm{C}$ mutations and protection against oxidative stress in mycobacteria. DNA Repair, v. 6, n. 12, p. 1774-1785, 2007. 
KAWAI, Y.; MORIYA, S.; OGASAWARA, N. Identification of a protein, YneA, responsible for cell division suppression during the SOS response in Bacillus subtilis. Molecular Microbiology, v. 47, n. 4, p. 1113-1122, 2003.

KIM, J. K.; CHOI, B. S. The Solution Structure of DNA Duplex-Decamer Containing the $(6-4)$ Photoproduct of Thymidylyl $\left(3^{\prime} \rightarrow 5^{\prime}\right)$ Thymidine by NMR and Relaxation Matrix Refinement. European Journal of Biochemistry, v. 228, n. 3, p. 849-854, 1995

KIM, Y. J.; WILSON III, D. M. Overview of base excision repair biochemistry. Current Molecular Pharmacology, v. 5, n. 1, p. 3, 2012.

KLAUNIG, J. E.; KAMENDULIS, L.M. The role of oxidative stress in carcinogenesis. Annual Review of Pharmacology and Toxicology, v. 44, p. 239-267, 2004.

KOHANSKI, M. A.; DWYER, D. J.; HAYETE, B.; LAWRENCE, C. A.; COLLINS, J. J. A common mechanism of cellular death induced by bactericidal antibiotics. Cell, v. 130, n. 5, p. 797, 2007.

KOHANSKI, M. A.; DEPRISTO, M. A.; COLLINS, J. J. Sublethal antibiotic treatment leads to multidrug resistance via radical-induced mutagenesis. Molecular Cell, v. 37, n. 3, p. 311$320,2010$.

KOVACIC, L.; PAULIC, N.; LEONARDI, A.; HODNIK, V.; ANDERLUH, G.; PODLESEK Z.; ZGUR-BERTOK, D.; KRIZAJ, I.; BUTALA, M. Structural insight into LexA-RecA* interaction. Nucleic Acids Research, v. 39, p. 6546- 6557, 2013.

KOWALCZYKOWSKI, S. C.; DIXON, D. A., A.; EGGLESTON, K.; LAUDER, S. D.; REHRAUER, W. M. Biochemistry of homologous recombination in Escherichia coli. Microbiological reviews, v. 58, n. 3, p. 401-465, 1994.

KROKAN, H.; STANDAL, R.; SLUPPHAUG, G. DNA glycosylases in the base excision repair of DNA. Biochemical Journal, v. 325, p. 1-16, 1997.

KUMARI, A.; MINKO, I. G.; HARBUT, M. B.; FINKEL, S. E.; GOODMAN, M. F.; LLOYD, R. S. Replication bypass of interstrand cross-link intermediates by Escherichia coli DNA polymerase IV. Journal of Biological Chemistry, v. 283, n. 41, p. 27433-27437, 2008.

KUPER, J.; KISKER, C. Damage recognition in nucleotide excision DNA repair. Current Opinion in Structural Biology, v. 22, n. 1, p. 88-93, 2012.

KUPER, J.; KISKER, C. DNA Helicases in NER, BER, and MMR. Advances in Experimental Medicine and Biology, v. 767, p. 203-224, 2013.

KURTHKOTI, K.; SRINATH, T.; KUMAR, P.; MALSHETTY, V. S.; SANG, P. B.; JAIN, R.; VARSHNEY, U. A distinct physiological role of MutY in mutation prevention in mycobacteria. Microbiology, v. 156, n. 1, p. 88-93, 2010. 
KUZMINOV, A. Recombinational repair of DNA damage in Escherichia coli and bacteriophage $\lambda$. Microbiology and Molecular Biology Reviews, v. 63, n. 4, p. 751-813, 1999.

LINDAHL, T. Instability and decay of the primary structure of DNA. Nature, v. 362, n. 6422, p. 709-715, 1993.

LIU, Y.; KAO, H. I.; BAMBARA, R. A. Flap endonuclease 1: a central component of DNA metabolism. Annual Review of Biochemistry, v. 73, n. 1, p. 589-615, 2004.

LOVELL, M. A.; MARKESBERY, W. R. Oxidative DNA damage in mild cognitive impairment and late-stage Alzheimer's disease. Nucleic Acids Research, v. 35, n. 22, p. 7497-7504, 2007.

MARQUES, R. C. P. Identificação de genes de reparo de DNA em Caulobacter crescentus através da seleção de clones sensíveis a agentes genotóxicos. 2008. Tese (Doutorado em Microbiologia) - Instituto de Ciências Biomédicas, Universidade de São Paulo, São Paulo, 2008.

MARTINS-PINHEIRO, M. Busca por genes relacionados a fenótipos mutadores em Caulobacter crescentus. 2007. Tese (Doutorado em Microbiologia) - Instituto de Ciências Biomédicas, Universidade de São Paulo, São Paulo, 2007.

MCVEY, M. Strategies for DNA interstrand crosslink repair: insights from worms, flies, frogs, and slime molds. Environmental and Molecular Mutagenesis, v. 51, n. 6, p. 646-658, 2010.

MICHAELS, M. L.; CRUZ, C.; GROLlMAN, A. P.; MILLER, J. H. Evidence that MutY and MutM combine to prevent mutations by an oxidatively damaged form of guanine in DNA. Proceedings of the National Academy of Sciences, v. 89, n. 15, p. 7022-7025, 1992.

MICHAELS, M. L.; MILLER, J. H. The GO system protects organisms from the mutagenic effect of the spontaneous lesion 8-hydroxyguanine (7, 8-dihydro-8-oxoguanine). Journal of Bacteriology, v. 174, n. 20, p. 6321, 1992.

MILES, G. M.;SANCAR, A. DNA repair. Chemical Research in Toxicology, v. 2, n. 4, p. 197-226, 1989.

MILLER, J. H. Experiments in molecular genetics. New York: Cold Spring Harbor, 1972. p. 466.

MILLER, C.; THOMSEN, L. E.; GAGGERO, C.; MOSSERI, R.; INGMER, H.; COHEN, S. N. SOS response induction by beta-lactams and bacterial defense against antibiotic lethality. Science, v. 305, n. 5690, p. 1629-1631, 2004.

MODELL, J. W.; HOPKINS, A. C.; LAUB, M. T. A DNA damage checkpoint in Caulobacter crescentus inhibits cell division through a direct interaction with FtsW. Genes \& Development, v. 25, n. 12, p. 1328-1343, 2011. 
MOOLENAAR, G. F.; VAN ROSSUM-FIKKERT, S.; VAN KESTEREN, M.; GOOSEN, N.Cho, a second endonuclease involved in Escherichia coli nucleotide excision repair. Proceedings of the National Academy of Sciences, v. 99, n. 3, p. 1467-1472, 2002.

MUKHERJEE, A.; CAO, C.; LUTKENHAUS, J. Inhibition of FtsZ polymerization by SulA, an inhibitor of septation in Escherichia coli. Proceedings of the National Academy of Sciences, v. 95, n. 6, p. 2885-2890, 1998.

NAPOLITANO, R.; JANEL-BINTZ, R.; WAGNER, J.; FUCHS, R. P. P. All three SOS-inducible DNA polymerases (Pol II, Pol IV and Pol V) are involved in induced mutagenesis. The EMBO Journal, v. 19, n. 22, p. 6259-6265, 2000.

NATHAN, P.; NEWTON, A. Identification of two new cell division genes that affect a highmolecular-weight penicillin-binding protein in Caulobacter crescentus. Journal of Bacteriology, v. 170, n. 5, p. 2319-2327, 1988.

NEELEY, W. L.; ESSIGMANN, J. M. Mechanisms of formation, genotoxicity, and mutation of guanine oxidation products Chemical Research in Toxicology, v. 19, n. 4, p. 491-505, 2006.

NEELEY, W. L.; DELANEY, S.; ALEKSEYEV, Y. O.; JAROSZ, D. F.; DELANEY, J. C.; WALKER, G. C.; ESSIGMANN, J. M. DNA polymerase V allows bypass of toxic guanine oxidation products in vivo. Journal of Biological Chemistry, v. 282, n. 17, p. 12741-12748, 2007.

NOHMI T. Environmental stress and lesion-bypass DNA polymerases. Annual Review of Microbiology, v. 60, p. 231-253, 2006.

OLLIVIERRE, J. N.; FANG, J.; BEUNING, P. J. The roles of UmuD in regulating mutagenesis. Journal of Nucleic Acids, v. 2010, p. 947680, 2010.

PARK, H.; ZHANG, K.; REN, Y.; NADJI, S.; SINHA, N.; TAYLOR, J. S.; KANG, C. Crystal structure of a DNA decamer containing a cis-syn thymine dimer. Proceedings of the National Academy of Sciences, v. 99, n. 25, p. 15965-15970, 2002.

PATRO, J. N.; WIEDERHOLT, C. J.; JIANG, Y. L.; DELANEY, J. C.; ESSIGMANN, J. M.; GREENBERG, M. M. Studies on the Replication of the Ring Opened Formamidopyrimidine, Fapy. dG in Escherichia coli. Biochemistry, v. 46, n. 35, p. 10202-10212, 2007.

PAZ-ELIZUR, T.; TAKESHITA, M.; GOODMAN, M.; O'DONNELL, M.; LIVNEH, Z. Mechanism of Translesion DNA Synthesis by DNA Polymerase II COMPARISON TO DNA POLYMERASES I AND III CORE. Journal of Biological Chemistry, v. 271, n. 40, p. 24662-24669, 1996.

PEARLMAN, D. A.; PIRKLE, D. H.; KIM, S. H. Molecular models for DNA damaged by photoreaction. Science, v. 227, n. 4692, p. 1304-1308, 1985.

PEREZ-CAPILLA, T.; BAQUERO, M. R., GOMEZ-GOMEZ, J. M., IONEL, A., MARTIN, S., BLAZQUEZ, J. SOS-independent induction of $\operatorname{din} B$ transcription by beta-lactam- 
mediated inhibition of cell wall synthesis in Escherichia coli. Journal of Bacteriology, v. 187, n. 4, p. 1515-1518, 2005.

PFEIFER, G. P. Formation and processing of UV photoproducts: effects of DNA sequence and chromatin environment. Photochemistry and Photobiology, v. 65, n. 2, p. 270-283, 1997.

PFEIFFER, P.; GOEDECKE, W., \& OBE, G. Mechanisms of DNA double-strand break repair and their potential to induce chromosomal aberrations. Mutagenesis, v. 15, n. 4, p. 289-302, 2000.

PHAM, P.; SEITZ, E. M.; SAVELIEV, S.; SHEN, X.; WOODGATE, R.; COX, M. M.; GOODMAN, M. F. Two distinct modes of RecA action are required for DNA polymerase Vcatalyzed translesion synthesis. Proceedings of the National Academy of Sciences, v. 99, n.17, p. 11061-11066, 2002.

PRENTKI, P.; KRISCH, H. M. In vitro insertional mutagenesis with a selectable DNA fragment. Gene, v. 29, n. 3, p. 303-313, 1984.

PLATA, K. B.; RIOSA, S.; SINGH, C. R.; ROSATO, R. R.; ROSATO, A. E. Targeting of PBP1 by $\beta$-lactams Determines recA/SOS Response Activation in Heterogeneous MRSA Clinical Strains. PloS One, v. 8, n. 4, p. e61083, 2013.

RANGANATHAN, S.; WALSH, E. S.; TEW, K. D. Glyoxalase I in detoxification: studies using a glyoxalase I transfectant cell line. Biochemical Journal, v. 309, p. 127-131, 1995.

RENZETTE, N.; GUMLAW, N.; SANDLER, S. J. DinI and RecX modulate RecA-DNA structures in Escherichia coli K-12. Molecular Microbiology, v. 63, n. 1, p. 103-115, 2007.

REHRAUER, W. M.; LAVERY, P. E.; PALMER, E. L.; SINGH, R. N.; KOWALCZYKOWSKIT S. C. Interaction of Escherichia coli RecA protein with LexA repressor. I. LexA repressor cleavage is competitive with binding of a secondary DNA molecule," Journal of Biological Chemistry, v. 271, n. 39, p. 23865-23873, 1996.

ROSCHE, W. A.; P. L. FOSTER. Determining mutation rates in bacterial populations. Methods, v. 20, n. 1, p. 4-17, 2000.

SAMBROOK, J.; RUSSEL, D. W. Molecular cloning: a laboratory manual. $3^{\text {rd }}$ ed. New York: Cold Spring Harbour Laboratory Press, 2001. v. 1-3.

SANDERS, L. H.; SUDHAKARAN, J.; SUTTON, M. D. The GO system prevents ROS-induced mutagenesis and killing in Pseudomonas aeruginosa. FEMS Microbiology Letters, v. 294, n. 1, p. 89-96, 2009.

SASSANFAR, M.; ROBERTS, J. W. Nature of the SOS-inducing signal in Escherichia coli. The involvement of DNA replication. Journal of Molecular Biology, v. 212, n. 1, p. 79-96, 1990.

SCHÄRER, O. D. Translesion DNA synthesis polymerases in DNA interstrand crosslink repair. Environmental and Molecular Mutagenesis, v. 51, n. 6, p. 552-566, 2010. 
SCHLACHER, K.; GOODMAN, M. F. Lessons from 50 years of SOS DNA-damage-induced mutagenesis. Nature Reviews Molecular Cell Biology, v. 8, n. 7, p. 587-594, 2007.

SETLOW, R.; CARRIER, W. L. Pyrimidine dimers in ultraviolet-irradiated DNA's. Journal of Molecular Biology, v. 17, n. 1, p. 237-254, 1966.

SHAW, K. J.; MILLER, N.; LIU, X.; LERNER, D.; WAN, J.; BITTNER, A.; MORROW, B. J. Comparison of the changes in global gene expression of Escherichia coli induced by four bactericidal agents. Journal of Molecular Microbiology and Biotechnology, v. 5, n. 2, p. 105-122, 2003.

SIMON, R.; PRIEFER, U.; PÜHLER, A. A broad host range mobilization system for in vivo genetic engineering: transposon mutagenesis in gram negative bacteria. Nature Biotechnology, v. 1, n. 9, p. 784-791, 1983.

SLUPPHAUG, G.; KAVLI, B.; KROKAN, H. E. The interacting pathways for prevention and repair of oxidative DNA damage. Mutation Research/Fundamental and Molecular Mechanisms of Mutagenesis, v. 531, n. 1, p. 231-251, 2003.

SZPILEWSKA, H.; BERTRAND, P.; BAILONE, A.; DUTREIX, M. In vitro inhibition of RecA-mediated homologous pairing by UmuD'C proteins. Biochimie, v. 77, n. 11, p. 848853, 1995.

TANG, M.; SHEN, X.; FRANK, E. G.; O'DONNELL, M.; WOODGATE, R.; GOODMAN, M. F. UmuD'(2)C is an error-prone DNA polymerase, Escherichia coli pol V. Proceedings of the National Academy of Sciences, v. 96, n. 16, p. 8919-8924, 1999.

TANG, M.; PHAM, P.; SHEN, X.; TAYLOR, J. S.; O'DONNELL, M.; WOODGATE, R.; GOODMAN, M. F. Roles of E. coli DNA polymerases IV and V in lesion-targeted and untargeted SOS mutagenesis. Nature, v. 404, n. 6781, p. 1014-1018, 2000.

THORNALLEY, P. J. Glutathione-dependent detoxification of $\alpha$-oxoaldehydes by the glyoxalase system: involvement in disease mechanisms and antiproliferative activity of glyoxalase I inhibitors. Chemico-biological Interactions, v. 111, p. 137-151, 1998.

TOMASZ, M. Mitomycin C: small, fast and deadly (but very selective). Chemistry \& Biology, v. 2, n. 9, p. 575-579, 1995.

TOUATI, D. Iron and oxidative stress in bacteria. Archives of Biochemistry and Biophysics, v. 373, n. 1, p. 1-6, 2000.

TRUGLIO, J. J.; CROTEAU, D. L.; VAN HOUTEN, B.; KISKER, C. Prokaryotic nucleotide excision repair: the UvrABC system. Chemical reviews, v. 106, n. 2, p. 233-252, 2006.

TSOKOS, C. G.; LAUB, M. T. Polarity and cell fate asymmetry in Caulobacter crescentus.Current Opinion in Microbiology, v. 15, n. 6, p. 744-750, 2012

VAN HOUTEN, B.; CROTEAU, D. L.; DELLAVECCHIA, M. J.; WANG, H.; KISKER, C. 'Close-fitting sleeves': DNA damage recognition by the UvrABC nuclease system. Mutation 
Research/Fundamental and Molecular Mechanisms of Mutagenesis, v. 577, n. 1, p. 92$117,2005$.

WAGNER, J.; GRUZ, P.; KIM, S. R.; YAMADA, M.; MATSUI, K.; FUCHS, R. P.; NOHMI, T. The dinB gene encodes a novel E. coli DNA polymerase, DNA pol IV, involved in mutagenesis. Molecular Cell, v. 4, n. 2, p. 281-286, 1999.

WALKER, G. C. Mutagenesis and inducible responses to deoxyribonucleic acid damage in Escherichia coli. Microbiological Reviews, v. 48, n. 1, p. 60, 1984.

WALLACE, S. S. Biological consequences of free radical-damaged DNA bases. Free Radical Biology and Medicine, v. 33, n. 1, p. 1-14, 2002.

WOODFORD, N.; ELLINGTON, M. J. The emergence of antibiotic resistance by mutation. Clinical Microbiology and Infection, v. 13, n. 1, p. 5-18, 2007.

ZEIBELL, K.; AGUILA, S.; SHI, V. Y.; CHAN, A.; YANG, H.; MILLER, J. H. Mutagenesis and repair in Bacillus anthracis: the effect of mutators. Journal of Bacteriology, v. 189, n. 6, p. 2331-2338, 2007.

ZHANG, J.; MADDEN, T. L. PowerBLAST: a new network BLAST application for interactive or automated sequence analysis and annotation. Genome Research, v. 7, n. 6, p. 649-656. 1997.

ZHARKOV, D. O. Base excision DNA repair. Cellular and Molecular Life Sciences, v. 65, n. 10, p. 1544-1565, 2008.

ZIETLOW, L.; BESSHO, T. DNA Polymerase I-mediated translesion synthesis in RecAindependent DNA interstrand cross-link repair in E. coli. Biochemistry, v. 47, n. 19, p. 54605464, 2008. 


\section{APENNDICE - Figuras}

Figura A1 - Efeito das deleções gênicas em CC_3424, CC_3467, CC_2040 e uvrA na resistência à $\mathrm{H}_{2} \mathrm{O}_{2} \mathrm{em} C$. crescentus.
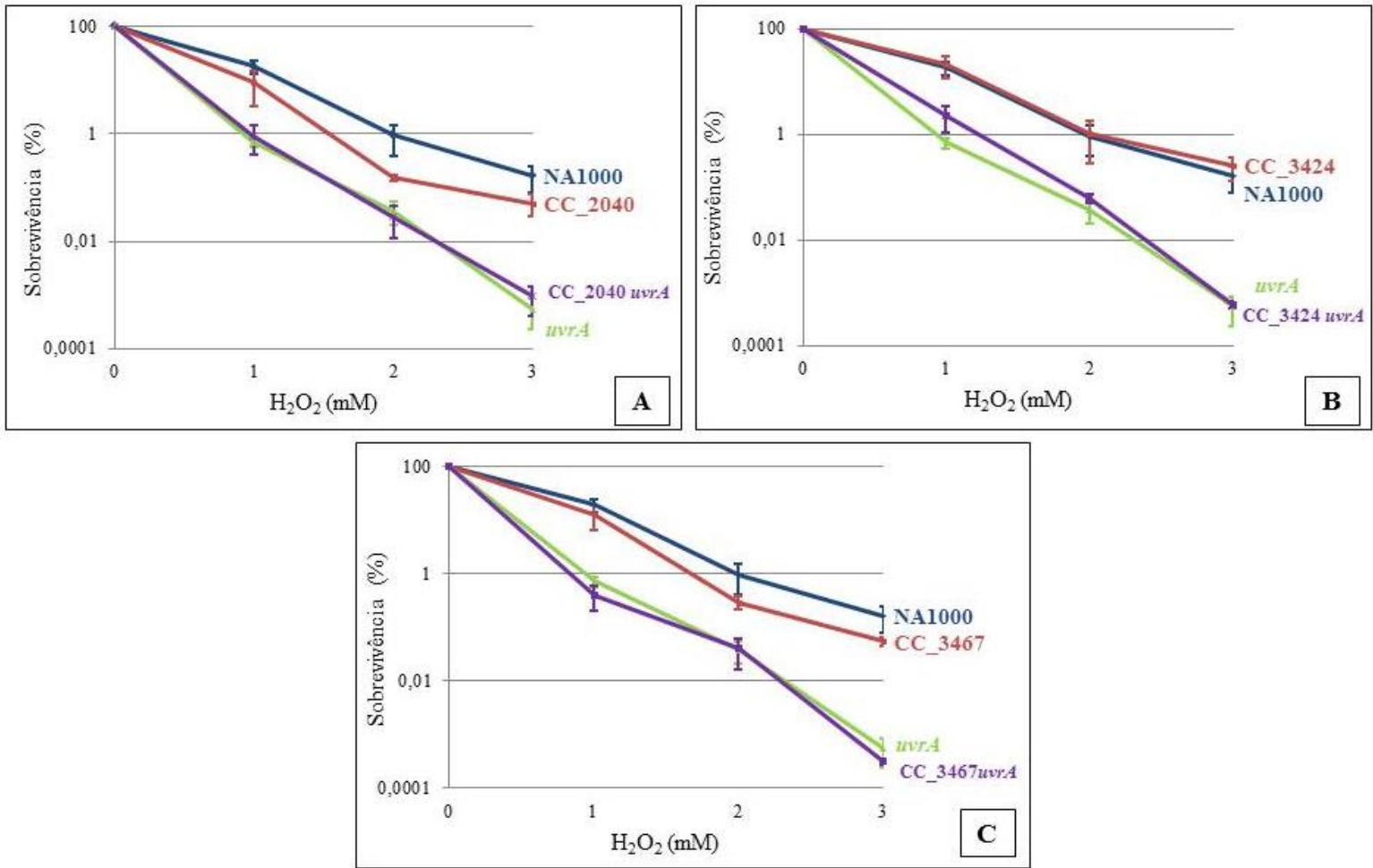

As células foram submetidas a tratamentos com concentrações de 1,2 e $3 \mathrm{mM}$ de $\mathrm{H}_{2} \mathrm{O}_{2}$ durante 60 minutos. A) cepas mutantes simples CC_2040 e $u v r A$ e o mutante duplo CC_2040 uvrA; B) cepas mutantes simples CC_3424 e uvrA e o mutante duplo CC_3424 uvrA; C) cepas mutantes simples CC_3467 e uvrA e o mutante duplo CC_3467 uvrA. É possível observar que os duplos mutantes não se mostraram mais sensíveis ao tratamento com $\mathrm{H}_{2} \mathrm{O}_{2}$ em relação aos respectivos mutantes simples. Os resultados representam a média de três experimentos independentes. 
Figura A2 - Efeito das deleções gênicas em CC_3424, CC_3467, CC_2040, CC_0627 e uvrA na resistência à MMS em $C$. crescentus.

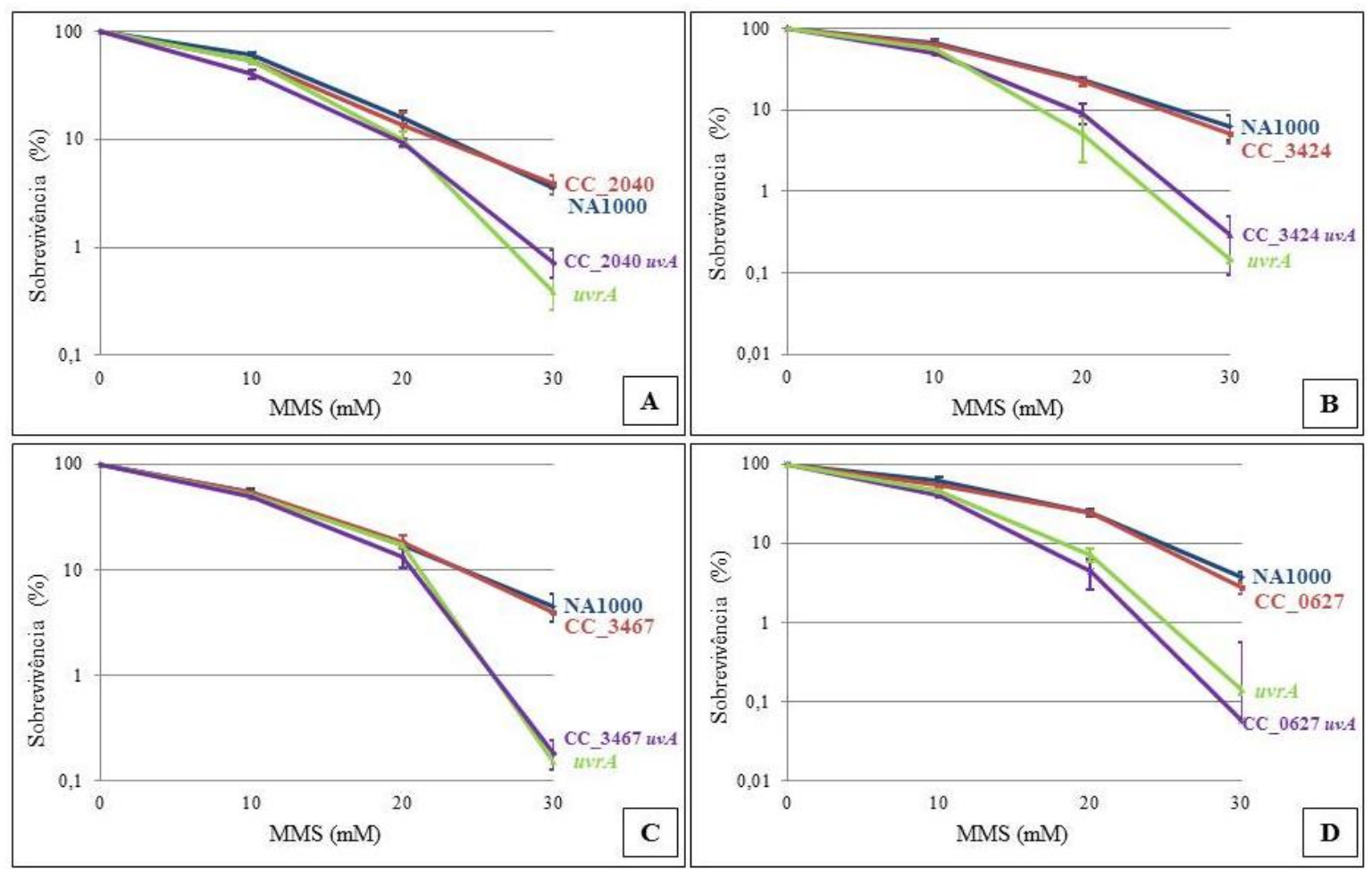

As células foram submetidas a tratamentos com concentrações de 10, 20 e $30 \mathrm{mM}$ de MMS durante 90 minutos. A) cepas mutantes simples CC_2040 e uvrA e o mutante duplo CC_2040 uvrA; B) cepas mutantes simples CC_3424 e uvrA e o mutante duplo CC_3424 uvrA; C) cepas mutantes simples CC_3467 e $u v r A$ e o mutante duplo CC_3467 uvrA. D) cepas mutantes simples CC_0627 e uvrA e o mutante duplo CC_0627 uvrA É possível observar que os duplos mutantes não se mostraram mais sensíveis ao tratamento com MMS em relação aos respectivos mutantes simples. Os resultados representam a média de três experimentos independentes. 
Figura A3 - Efeito das deleções gênicas em CC_3424, CC_3467, CC_2040 e uvrA na resistência à luz UVC em $C$. crescentus.
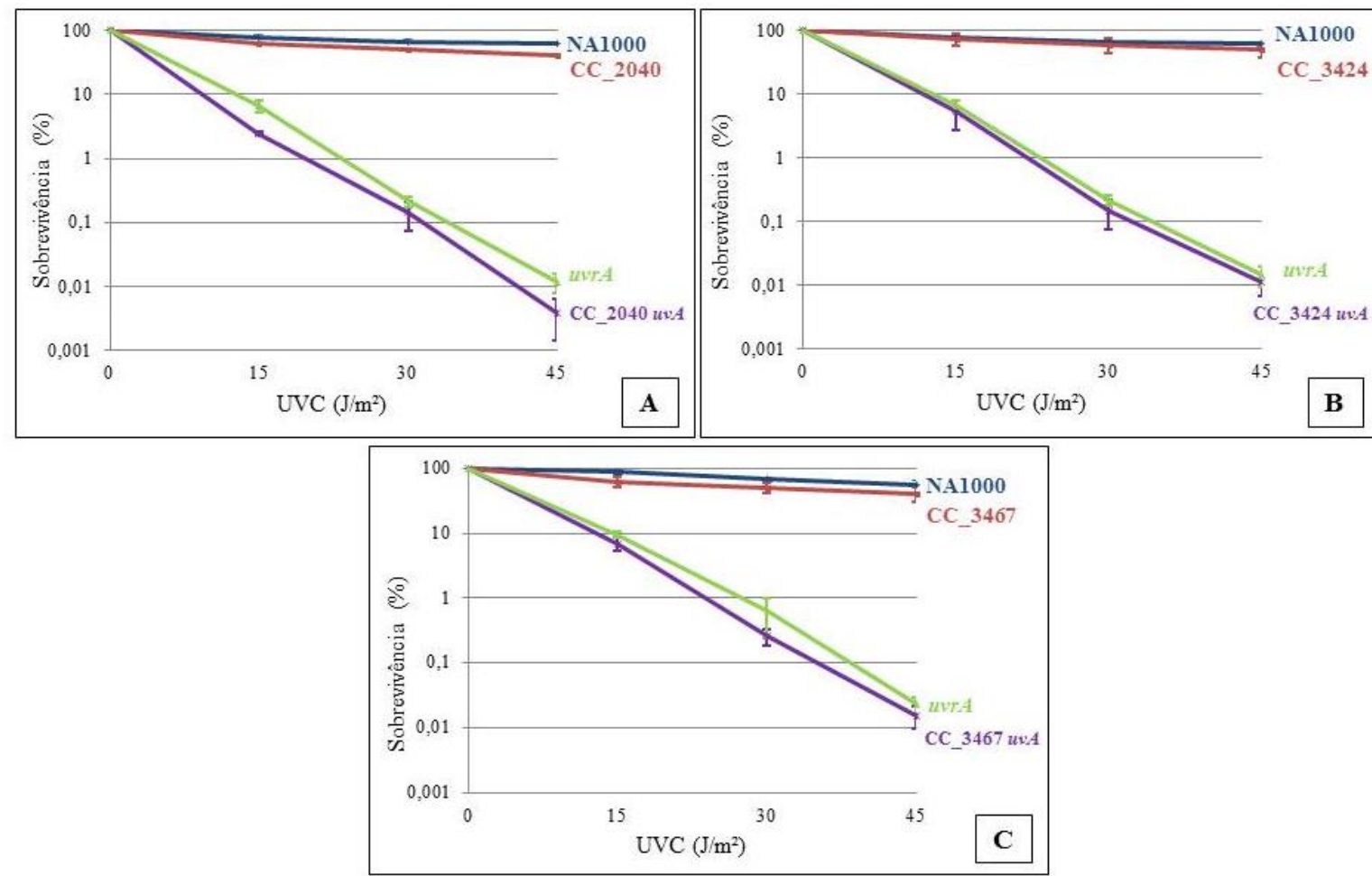

As células foram irradiadas com doses de 50,100 e $150 \mathrm{~J} / \mathrm{m}^{2}$ de luz UVC. A) cepas mutantes simples CC_2040 e $u v r A$ e o mutante duplo CC_2040 $u v r A$; B) cepas mutantes simples CC_3424 e $u v r A$ e o mutante duplo CC_3424 uvrA; C) cepas mutantes simples CC_3467 e uvrA e o mutante duplo CC_3467uvrA. É possível observar que os duplos mutantes não se mostraram mais sensíveis ao tratamento com luz UVC em relação aos respectivos mutantes simples. Os resultados representam a média de três experimentos independentes. 
Figura A4 - Alinhamento da sequência de aminoácidos da proteína codificada pelo gene CC_3467 para análise de domínios de similaridade.

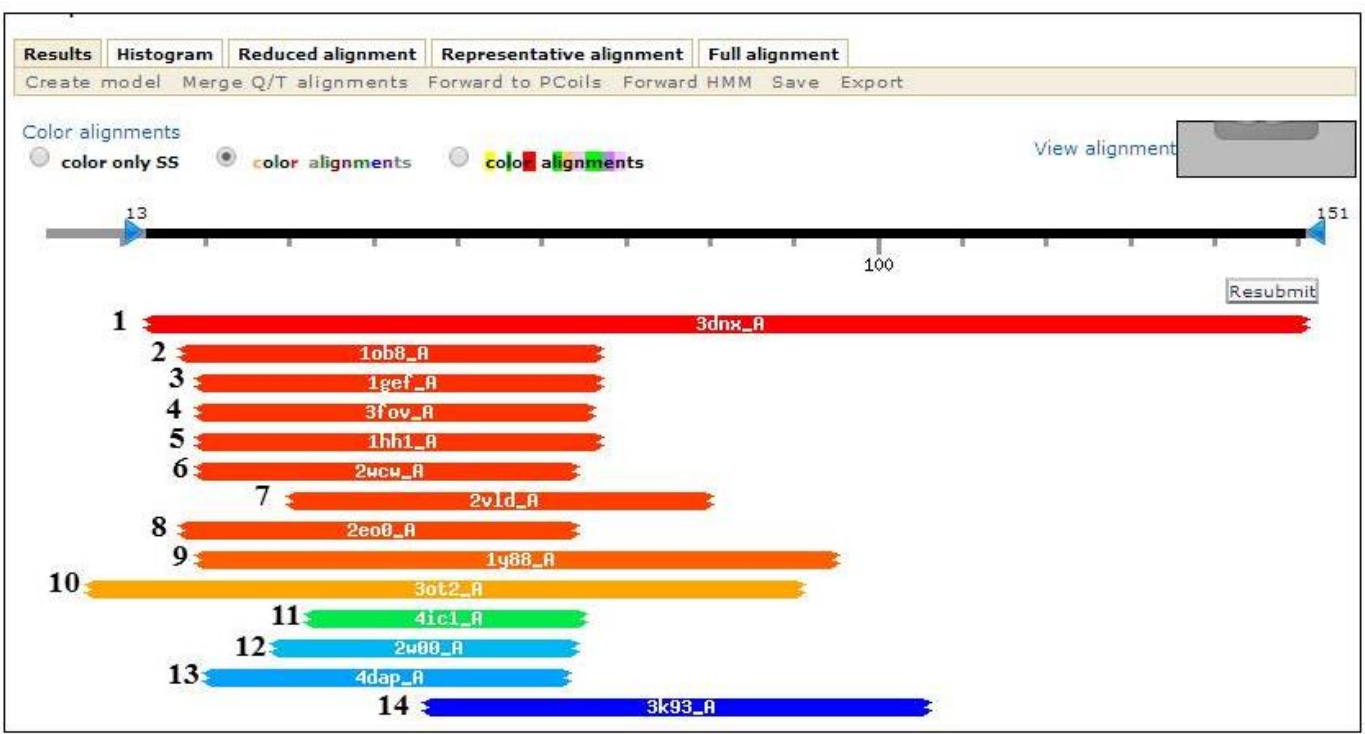

Análises de domínios protéicos utilizando-se o software HHPRED mostraram que o gene CC_3467 apresenta domínios protéicos com similaridade a diversas proteínas: 1) hipotética, 2) resolvase de junção Holliday, nuclease, hidrolase, nuclease, 3) resolvase de junção Holliday, hidrolase, 4) hipotética, 5) resolvase de junção Holliday, nuclease, 6) endonuclease, hidrolase, resolvase de junção de Holliday, 7) endonuclease, hidrolase, 8) hipotética, resolvase de junção de holliday, 9) hipotética, 10) hipotética, 11) hipotética, 12) ligadora de ATP, ligadora de DNA, helicases, 13) Nuclease, ligadora de DNA, 14) exonuclease, hidrolase. 
Figura A 5 - Alinhamento da sequência de aminoácidos da proteína codificada pelo gene CC_3424 para análise de domínios de similaridade.

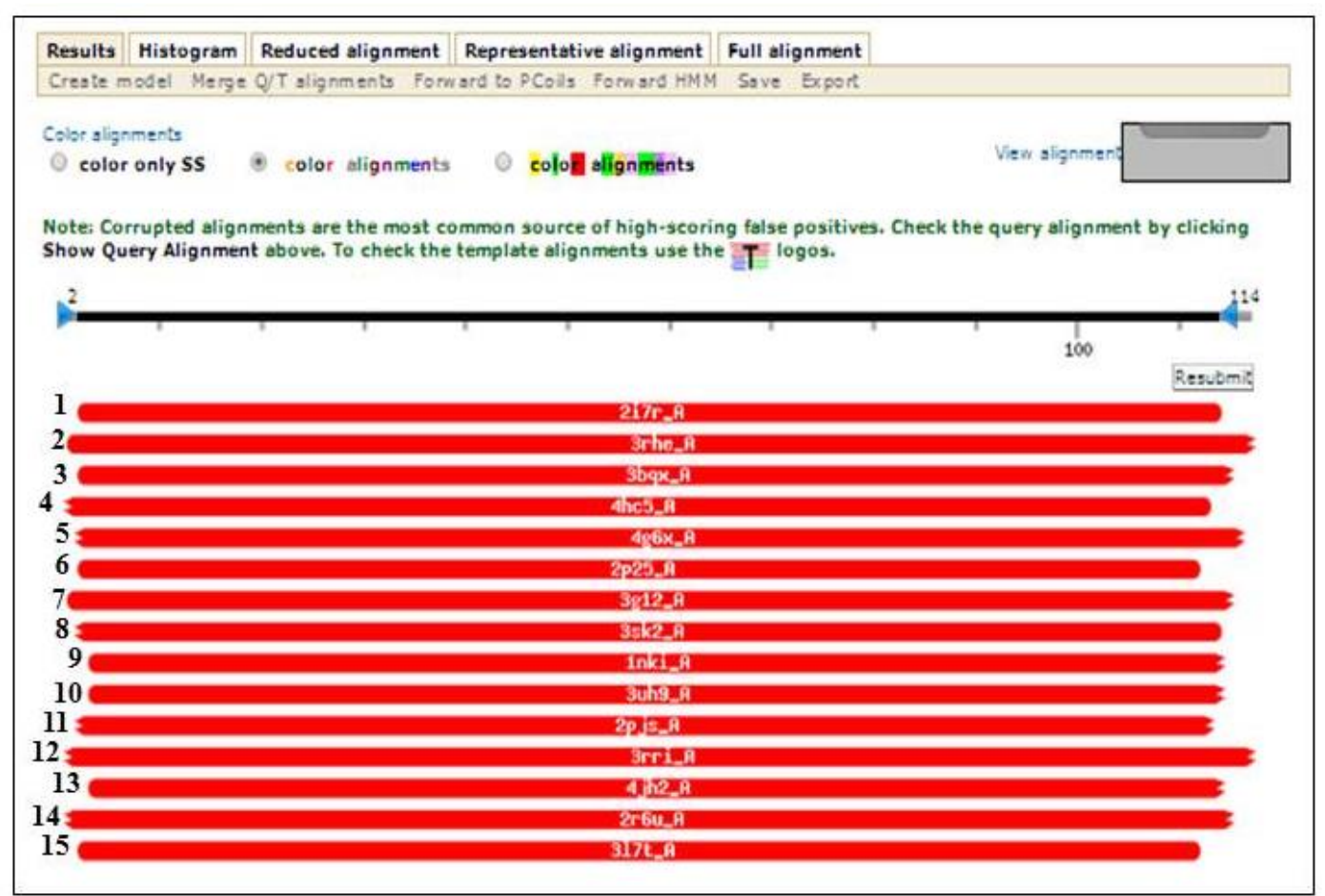

Análises de domínios protéicos utilizando-se o software HHPRED mostraram que o gene CC_3467 apresenta domínios protéicos com similaridade a diversas proteínas: 1) hipotética, 2) benzaldeído desidrogenase (NADP+), 3) glioxalase, 4) glioxalase, dioxigenase, proteína relacionada com resistência a bleomicina, 5) glioxalase, dioxigenase, proteína relacionada com resistência a bleomicina, 6) glioxalase, 7) glioxalase, proteína relacionada com resistência a bleomicina, 8) proteína relacionada com resitência a antibióticos, 9) proteína relacionada com resistência a fosfomicina, 10) proteína relacionada com resistência a fosfomicina, 11) hipotética, glioxalase, dioxigenase, proteína relacionada com resistência a bleomicina, 12) glioxalase, dioxigenase, proteína relacionada com resistência à bleomicina, 13) proteína relacionada com resistência a fosfomicina, 14) hipotética, 15) hipotética, proteína ligadora a metais. 